\title{
Otolarinyngesolology
}

VOLUME 111

JANUARY THROUGH DECEMBER 1985

American Medical Association Publication 


\section{AUTHOR INDEX TO VOLUME 111}

In this Index in alphabetical order are listed the names of authors of all articles and letters. Full citation is given under first author only; reference is made from joint authors. Reviewers of books are listed in the Author Index. Names which begin with a prefix are entered under the prefix.

\section{A}

Abedi E see Lenhardt ML

Abrams AM see Handlers JP

Abramson AL see Stegnjajic A

Abramson AL, Brandsma J, Steinberg B, Winkler

B: Verrucous carcinoma of larynx, $709(\mathrm{No})$

Adams GL see Griebie M; Hilger PA

Adamson PA, Johnson CM Jr, Anderson JR, Dupin CL: Forehead lift, 325 (My)

Adkins WY Jr: Atlas of Ear, Nose, and Throat

Diseases, Including Bronchoesophagology (Book Review) 418 (Je)

Adler C-P see Ikenberg H

Alexander GD: Dangers of propranolol withdrawal prior to local anesthesia with epinephrine (letter) 280 (Ap)

Alford BR see Shoss SM

Allan JH, Cook TA: Computer-based method of filing photographs and procedures, $178(\mathrm{Mr})$

Amendola BE see Wolf GT

Anderson JR see Adamson PA

Anderson. JR: Scale for evaluating results of rhinoplasty, $520(\mathrm{Au})$

Andrews ML see Tardy-Mitzell S

Applebaum EL, Valvassori GE: Effects of magnetic resonance imaging fields on stapedectomy prostheses, 820 (De)

Arena $S$ see Gullane PJ

Arenberg IK see Ferraro JA

Aronsohn RB: Injectable liquid silicone (letter) $70(\mathrm{Ja})$

Åsbrink E, Olsson I, Hovmark A, Carlsson B: Facial palsy (letter) 349 (My)

Atiyah RA, Wurster CF, Fritsch MA, Sisson GA: Resident's page, $204(\mathrm{Mr})$

Ator GA see Coker NJ

\section{B}

Bailey BJ:

Challenge to otolaryngology, $1(\mathrm{Ja})$

Give a priceless gift this year, 777 (De)

Misuse in terminology? (letter) $485(\mathrm{Jy})$

Mitomycin and fluorouracil and concomitant radiotherapy in head and neck cancer (editorial footnote) 222 (Ap)

Near-total pharyngeal reconstruction by 'rotary-door' sternohyoid myocutaneous flap in $\operatorname{dog}$ (editorial footnote) 676 (Oc)

Smokeless tobacco, 707 (No)

Twisted larynx (ed reply) 557 ( $\mathrm{Au}$ )

We must stop selling cancer to our children, $637(\mathrm{Oc})$

Baker DC see Glasscock ME III

Baker SR, Swanson NA: Oblique forehead flap

for total reconstruction of nasal and columella, 425 (Jy)

Barat M, Sciubba JJ: Resident's page, 276 (Ap)

Barnes EL see Johnson JT

Barnes L see Kaplan B; Merwin WH Jr

Barrilleaux CN see Moore PJ
Barrs DM, Brackmann DE, Olson JE, House WF: Changing concepts of acoustic neuroma diagnosis, 17 (Ja)

Batsakis JG see Kraemer BB

Beahrs OH see DeSanto LW

Beall J, Scholl P, Jafek B: Total ophthalmoplegia after internal maxillary artery ligation, 696 (Oc)

Bedetti CD see Johnson JT

Beekhuis GJ see Colton JJ

Bello EF, Pien FD: Salmonella dublin neck abscess, 476 (Jy)

Belmont JR: Approach to iarge nasuseptal perfcrations and attendant deformity, $450(\mathrm{Jy})$

Ben-David $J$ see Fradis $M$

Benjamin DM see Greenblatt DJ

Berghaus A: Porous polyethylene in reconstructive head and neck surgery, $154(\mathrm{Mr})$

Biller HF see Surkin $\mathbf{M}$

Biller HF, Urken M: Cricoid collapse, 740 (No)

Björkander J see Karlsson G

Blanks RHI see deBerry-Borowiecki B

Blessing ML see Wetmore SJ

Blitzer PH: Irradiation after neck dissection (letter) $827(\mathrm{De})$

Blom ED see Hamaker RC

Blom ED, Singer MI: Tracheoesophageal puncture prostheses (letter) $208(\mathrm{Mr}$ )

Blom ED, Singer MI, Hamaker RC: Improved esophageal insufflation test, 211 (Ap)

Bodo $\mathbf{G}$ see lkenberg $\mathbf{H}$

Boles R: Surgery of Larynx (Book Review) 776 (No)

Bowman CA see Todd NW Jr

Bowman SA see Tardy-Mitzell S

Brackmann DE see Barrs DM; Horn KL

Brandsma J see Abramson AL

Bratcher GO see Welsh R

Brecht K, Johnson CM III: Complete mandibular agenesis, $132(\mathrm{Fe})$

Briant TD see Forte $V$

Brimacombe JA see Edgerton BJ

Broniatowski M see Tucker HM

Broniatowski M, Eliachar I, Levine S, Sebek B, Tucker HM: Near-total pharyngeal reconstruction by 'rotary-door' sternohyoid myocutaneous flap in dog, 673 (Oc)

Brousseau DA see Silverman DG

Brown DT, Litt M, Potsic WP: Study of mucus glycoproteins in secretory otitis media, 688 (Oc)

Brown MM: Resident's page, 486 (Jy)

Brummett RE: Otolaryngologists using local anesthetics containing epinephrine (letter) 281 (Ap)

Burgess LPA, Yim DWS: Laryngeal cyst of thyroid cartilage, $826(\mathrm{De})$

Burns DK see Schaefer SD

Burstein FD see Canalis RF; Rice DH

\section{C}

Calcaterra TC see Kessler DJ; Zemplenyi J

Canalis RF, Burstein FD: Osteogenesis in vascularized periosteum, $511(\mathrm{Au})$

Cangir A see Goepfert $H$

Cannon CR, Fechner RE: Resident's page, 702 (Oc)

Cantekin EI see Fria TJ

Cantrell RW see Kaplan MJ

Cantrell RW: Atlas of Laryngeal Surgery (Book

Review) $561(\mathrm{Au})$

Carey TE see Roa RA

Carlsöö B see Gustafsson H

Carlsson B see Åsbrink E

Cartun RW see Zarbo RJ

Cartwright RD: Predicting response to tongue retaining device for sleep apnea syndrome, 385 (Je)

Caruso R see Denaro A

Castro DJ, Hoover L, Castro DJ, Zuckerbraun L:

Cervical mycobacterial lymphadenitis, 816 (De)

Catlin FI: Prevention of hearing impairment

from infection and ototoxic drugs, 377 (Je)

Chase S see Tucker HM

Chole RA: Recent Advances in Otitis Media with

Effusion (Book Review) $563(\mathrm{Au})$

Chrisman BB: Forehead lift (letter) 827 (De)

Christen AG see Schaefer SD

Churukian MM see Kamer FM

Cinberg JZ, Rosenbaum FA, Lowrie C, Gorman

M: Calvarial grafts for midface rehabilitation 434 (Jy)

Clark WD see Clegg TJ

Clegg TJ, Clark WD: Resident's page 634 , (Se)

Close LG see Schaefer SD

Coker NJ see Kearns DB

Coker NJ, Ator GA, Jenkins HA, Neblett CR,

Morris JR: Carbon dioxide laser stapedotomy, 601 (Se)

Colclasure JB, Graham SS: Support of unstable nasal fractures with silicone rubber wedge splints, $443(\mathrm{Jy})$

Cole TB see Fisher SR

Colton JJ, Beekhuis GJ: Use of electrosurgery in blepharoplasty, 441 (Jy)

Conley J:

Intranasal composite grafts for dorsal support, 241 (Ap)

Management of ear canal in head and neck surgery, $90(\mathrm{Fe})$

Conley J, Norris JEC: Reconstruction of half of face, $142(\mathrm{Mr})$

Conley J, Tinsley PP Jr: Treatment and prognosis of mucoepidermoid carcinoma in pediatric age group, $322(\mathrm{My})$

Constable WC see Kaplan MJ

Cook TA see Allan JH

Cotton RT see Welsh R 
Cotton RT:

Nasopharyngeal stenosis, $146(\mathrm{Mr})$

Pediatric Plastic Surgery (Book Review) 490 (Jy)

Cremers C, Theunissen E, Kuijpers W: Proximal symphalangia and stapes ankylosis, 765 (No)

Cremers CWRJ, Hombergen GCHJ, Scaf JJ, Huygen PLM, Volkers WS, Pinckers AJLG: $\mathrm{X}$-linked progressive mixed deafness with perilymphatic gusher during stapes surgery, 249 (Ap)

Crews P see Reed HT

Cummings CW, Trachy RE: Measurement of alternative blood flow in porcine panniculus carnosus myocutaneous flap, 598 (Se)

Cutrona D see Denaro A

\section{D}

D'Arrigo C see Denaro A

Daniel RK see Lessard $M-L$

Daniels HA see Hamaker RC

Danielson JR see Walter RJ

Davidge-Pitts KJ see Gregor RT

Davis JW see Wurster CF

Davis 0 , Powell W: Auricular perichondritis secondary to acupuncture, 770 (No)

Davis O, Wolff AP: Resident's page, $558(\mathrm{Au})$

Davis O, Yeh S: Resident's page, 412 (Je)

Davis RK see Stevens MH

De Vito MA, Malmgren LT, Gacek RR: Threedimensional distribution of neuromuscular junctions in human cricothyroid, $110(\mathrm{Fe})$

deBerry-Borowiecki B, Kukwa AA, Blanks RHI:

Indications for palatopharyngoplasty, 659 (Oc)

Denaro A, Caruso R, Rossi M, D'Arrigo C, Malaponte G, Mazzarino MC, Cutrona D: Circulating immunocomplexes and laryngeal carcino$\mathrm{ma}, 595(\mathrm{Se})$

DeSanto LW: Irradiation after neck dissection (letter) 828 (De)

DeSanto LW, Beahrs OH, Holt JJ, O'Fallon WM: Neck dissection and combined therapy, 366 (Je)

Deutsch EC, Schild JA, Mafee MF: Dysphagia and Forestier's disease, $400(\mathrm{Je})$

Diaz JA see Ruff T

Diaz R see Wolf GT

Dierks EJ, Perry DA: Resident's page, 346 (My)

DiFazio CA see Ruth RA

Doiron D see Keller GS

Doiron DR see Keller GS

Donovan DT see Shoss SM

Doyle WJ: Eustachian tube function in chinchilla, 305 (My)

Doyle WJ, Taka:ara T, Fireman P: Role of allergy in pathogenesis of otitis media with effusion, $502(\mathrm{Au})$

Dupin CL see Adamson PA

Duplechin JK see Hagan WE

\section{$\mathbf{E}$}

Eavey RD see Sillman JS

Edgerton BJ see Terr LI

Edgerton BJ, Brimacombe JA, House WF: Auditory capabilities of single-channel cochlear implant patients, 255 (Ap)

Eichler JA see Fria TJ

Einhaeupl K, Pfister H-W: Facial palsy in Bann-

warth's syndrome (letter) $557(\mathrm{Au})$

Einhorn LH see Zeph RD

Eliachar I see Broniatowski M

Eller PM see Moran DT

Elliott CL see Moorthy SS

Ellis JC, McCaffrey TV: Nerve grafting, 781 (De)

Emerson E see Schwenzfeier CW

English JL see McCullough EG

Etheridge JG see Walker AN
Fechner RE see Cannon CR

Fee WE Jr: Skull Base Surgery (Book Review) 562 (Au)

Ferraro JA, Arenberg IK, Hassanein RS: Electrocochleography and symptoms of inner ear dysfunction, $71(\mathrm{Fe})$

Fireman $P$ see Doyle WJ

Fisher GU see Keller GS

Fisher SR, Cole TB, Meyers WG, Seigler HF: Pharyngoesophageal reconstruction using free jejunal interposition grafts, 747 (No)

Flöel H see Mann WJ

Forte V, Middleton WG, Briant TD: Expansion of myocutaneous flaps, 371 (Je)

Fradis M, Podoshin L, Ben-David J, Reiner B: Treatment of Meniere's disease by intratympanic injection with lidocaine, 491 (Au)

Fredrickson JM: Atlas of Speech and Hearing Anatomy (Book Review) 633 (Se)

Freeman P, Salamonsen RF, Mainland JF: Inhalation of carbon dioxide mixtures for sensorineural deafness, $75(\mathrm{Fe})$

Fria TJ, Cantekin EI, Eichler JA: Hearing acuity of children with otitis media with effusion, 10 (Ja)

Friedman WH, Rosenblum BN, Katsantonis GP: Contralateral laryngoplasty, 742 (No)

Frierson HF Jr: Resident's page, 136 (Fe)

Fritsch MA see Atiyah RA

Fung RQ, Ronis ML, Mohr RM: Use of butyl2-cyanoacrylate in rabbit auricular cartilage, $459(\mathrm{Jy})$

\section{G}

Gacek RR see De Vito MA

Gacek RR: Hearing Disorders (Book Review) 419 (Je)

Gal TJ see Ruth RA

Garcia MJS see Nieto CS

Garcia PB see Nieto CS

Gates GA: Management of patients with tinnitus (letter) 631 (Se)

Gates TC see Puthawala AA

Giandello PR see Webster RC

Giebink GS see Morizono T

Giffin CS: Wrestler's ear (acute auricular hematoma), $161(\mathrm{Mr})$

Gilsbach J see Mann WJ

Gissmann $L$ see Ikenberg $H$

Glasscock ME III, Pensak ML, Gulya AJ, Baker

DC: Lyme disease, $47(\mathrm{Ja})$

Glover ED see Schaefer SD

Gnepp DR see Schroeder W

Godoy J, Mathog RH: Malar fractures associated with exophthalmos, $174(\mathrm{Mr})$

Goepfert H see Kraemer BB

Goepfert H: Pharyngoesophageal reconstruction (letter) 706 (Oc)

Goepfert H, Cangir A, Lee Y-Y: Chemotherapy for aggressive juvenile nasopharyngeal angiofibroma, 285 (My)

Goin DW see lerokomos A

Goins MA III see Pearlman RC

Goldenberg RA: Lateral sinus thrombosis, 56 (Ja)

Goldman JM see Vitug AC

Goldstein JC see Koltai PJ

Goldstein JC: Problems in Head and Neck Surgery (Book Review) 563 (Au)

Gomis JE see Nieto CS

Gorman M see Cinberg JZ

Graham SS see Colclasure JB

Greenblatt DJ, Benjamin DM, Willis CR, Harmatz JS, Zinny MA: Lidocaine plasma concentrations following administration of intraoral lidocaine solution, 298 ( $\mathrm{My}$ )

Greenwood JH see Roa RA

Gregor RT, Davidge-Pitts KJ: Trapezius osteo-
Gregor RT - Continued

myocutaneous flap for mandibular reconstruction, 198 (Mr)

Griebie M, Adams GL: Clostridium difficile colitis following head and neck surgery, $550(\mathrm{Au})$ Griffin WL see Walker AN

Guberina L see Stegnjajic A

Gullane PJ, Arena S: Extended palatal island mucoperiosteal flap, 330 (My)

Gulya AJ see Glasscock ME III

Gustafsson H, Kjörell U, Carlsöö B: Cytoskeletal proteins in oncocytic tumors of parotid gland, $99(\mathrm{Fe})$

Guth PS see Reed HT

Guthrie TH Jr, Gynther L: Acute deafness, 344 (My)

Gynther L see Guthrie TH Jr

$$
\text { H }
$$

Hagan WE, Riveras E, Duplechin JK: Resident's page, 772 (No)

Hall JW III, Mackey-Hargadine JR, Kim EE: Auditory brain-stem response in determination of brain death, 613 (Se)

Hall MG Jr see Myers EM

Hamaker RC see Blom ED

Hamaker RC, Singer MI, Blom ED, Daniels HA: Primary voice restoration at laryngectomy, $182(\mathrm{Mr})$

Hammerschmidt RM see Wolf GT

Handlers JP, Waterman J, Abrams AM, Melrose RJ: Oral features of Wegener's granulomatosis, 267 (Ap)

Hanson LA see Karlsson G

Harmatz JS see Greenblatt DJ

Harnsberger HR see Stevens MH

Hassanein RS see Ferraro JA

Haughey BH, Panje WR: Extension of musculocutaneous flap by surgical delay, 234 (Ap)

Healy GB see O'Sullivan TJ

Healy GB: Ventilating tubes (letter) 416 (Je)

Henderson AH see Schaefer SD

Hergils L, Magnuson B: Morning pressure in middle ear, 86 ( $\mathrm{Fe})$

Hilger PA, Adams GL: Mandibular reconstruction with A-O plate, 469 (Jy)

Hill JH, Mafee MF, Lygizos NA, Soboroff BJ: Dynamic computed tomography, 62 (Ja)

Hirano $M$, Kurita S, Terasawa R: Difficulty in high-pitched phonation by laryngeal trauma, $59(\mathrm{Ja})$

Holt GR see Holt JE

Holt GR: Aesthetic Plastic Surgery (Book Review) 417 (Je)

Holt JE, Holt GR: Blepharoplasty, 394 (Je)

Holt JE, Holt GR, Van Kirk M: Use of temporalis fascia in eyelid reconstruction, $165(\mathrm{Mr})$

Holt JJ see DeSanto LW

Holtz F, Magielski JE: Synovial sarcomas of tongue base, 271 (Ap)

Hombergen GCHJ see Cremers CWRJ

Honjo I see Tanabe $M$

Honjo I, Tanaka S, Tanabe M: Pathogenesis of protruded false vocal fold, 398 (Je)

Hoover L see Castro DJ

Horn KL, Shea JJ III, Brackmann DE: Congenital cholesteatoma of petrous pyramid, 621 (Se)

House WF see Barrs DM; Edgerton BJ

Hovmark A see Åsbrink E

Hsu S see Roa RA

Hudson JL see Roa RA

Huygen PLM see Cremers CWRJ

lerokomos A, Goin DW: Primary CNS lymphoma in cerebellopontine angle, $50(\mathrm{Ja})$

Ikenberg H, Neumann-Haefelin D, Richthammer B, Wolfart W, Adler C-P, Bodo G, Gissmann L, zur Hausen $\mathbf{H}$ : Interferon therapy for bronchial 
Ikeenberg $\mathbf{H}$-Continued

ppapillomatosis controlled by papillomavirus-

IDNA hybridization, 96 (Fe)

Inoo C see Yamashita $T$

loaechim HL see Ryan JR

Isstshiki $\mathbf{N}$ see Tanabe $M$

Jafifek B see Beall J

Jaffek BW see Moran DT

Jayy J, Shapiro BM, Komisar A, Lawson W: Post-

$t$ traumatic pseudoaneurysm of extracranial rmiddle meningeal artery, 264 (Ap)

Jeenkins HA see Coker NJ; Kearns DB

Jobhns ME see Kaplan MJ; Kennedy DW

Jobhns ME: Oral Oncology (Book Review) 417 ( (Je)

Jobhnson CM III see Brecht $K$

Jobhnson CM Jr see Adamson PA

Jobhnson JB: Misuse in terminology? (letter) 485 ( ( Jy)

Joohnson JT, Myers EN, Bedetti CD, Barnes EL,

(Schramm VL Jr, Thearle PB: Cervical lymph

I node metastases, 534 (Au)

Joohnson JT, Myers EN, Srodes CH, Mayernik

I DG, Sigler BA, Schramm VL Jr, Nolan TA,

Wagner RL: Maintenance chemotherapy for high-risk patients, 727 (No)

Joohnson LP see Stevens MH

Joohnsson L-G see Palva T

Joones PF see Walker AN

K

Káamer FM, Churukian MM: Injectable liquid silicone (letter) $70(\mathrm{Ja})$

Kaaplan B, Barnes L: Oral lichen planus and squamous carcinoma, $543(\mathrm{Au})$

KKaplan MJ, Hahn SS, Johns ME, Stewart FM, Constable WC, Cantrell RW: Mitomycin and fluorouracil with concomitant radiotherapy in head and neck cancer, $220(\mathrm{Ap})$

KKarlsson G, Petruson B, Björkander J, Hanson LA: Infections of nose and paranasal sinuses in adult patients with immunodeficiency, 290 (My)

KKarmody CS see Wang $L$

KKassner GW see Mclntosh WA

KKatjalainen $S$ see Vartiainen $E$

KKatsantonis GP see Friedman WH

KKearns DB, Coker NJ, Pitcock JK, Jenkins HA Tuberculous petrous apicitis, 406 (Je)

KKeller GS, Doiron D, Weingarten C: Advances in laser skin surgery for vascular lesions, 437 (Jy)

KKeller GS, Doiron DR, Fisher GU: Photodynamic therapy in otolaryngology-head and neck surgery, 758 (No)

KKennedy DW: Functional endoscopic sinus surgery, 643 (Oc)

KKennedy DW, Zinreich SJ, Rosenbaum AE, Johns ME: Functional endoscopic sinus surgery, 576 (Se)

KKessler DJ, Mickel RA, Calcaterra TC: Malignant salivary gland tumors at base of tongue, 664 (Oc)

KKim EE see Hall JW III

KKimmelman CP see Nakashima T

KKirchner JA see Souliere CR Jr

KKitahara $M$ see Yazawa $Y$

KKitt VV see Panje WR

KKjörell U see Gustafsson H

K Klein $\mathbf{H Z}$ see Lanser $\mathbf{M J}$

K Klug D see Leipzig B

K Knibbs DR see Zarbo RJ

K Kniffin SA see Silverman DG

Kohut RI: Meniere's disease (syndrome?) 494 (Au)

Koltai PJ, Goldstein JC, Parnes SM, Price JC: External rhinoplasty approach to transsphenoidal hypophysectomy, $456(\mathrm{Jy})$
Komisar A see Jay $J$

Koolemans-Beynen A see Schuller DE

Koranda FC, Webster RC: Trapdoor effect in nasolabial flaps, 421 (Jy)

Kowalczyk PDH see Zarbo RJ

Kraemer BB, Srigley JR, Batsakis JG, Silva EG Goepfert H: DNA flow cytometry of thyroid neoplasms, 34 (Ja)

Kramer SJ: Short-Latency Auditory Evoked Potentials (Book Review) 490 (Jy)

Krause CJ see Maceri DR

Krepsi YP see Wurster CF

Krishna G see Moorthy SS

Krueger $K$ see Wetmore $S J$

Kuijpers $W$ see Cremers $C$

Kukwa AA see deBerry-Borowiecki B

Kumazawa $T$ see Yamashita $T$

Kurita $\mathbf{S}$ see Hirano $M$

\section{$\mathbf{L}$}

Lampe HB see Maceri DR

Lanser MJ, Klein HZ, Marvin A: Resident's page 486 (Jy)

Larrabee WF Jr see Walike JW

Larrabee WF Jr, Maupin G, Sutton D: Profile analysis in facial plastic surgery, $682(\mathrm{Oc})$

Lawson VG: Oral cavity reconstruction using pectoralis major muscle and amnion, 230 (Ap)

Lawson W see Jay J; Surkin M

Lee $Y-Y$ see Goepfert $H$

Lehto V-P see Paiva T

Leipzig B, Wetmore SJ, Putzeys R, Suen JY, Snyderman NL: Cisplatin potentiation of radiotherapy, $114(\mathrm{Fe})$

Leipzig B, Zellmer JE, Klug D, Panendoscopy Study Group: Role of endoscopy in evaluatin patients with head and neck cancer, 589 (Se)

LeLiever WC: Vestibular System (Book Review) $562(\mathrm{Au})$

Lenhardt ML, Shaia FT, Abedi E: Brain-stem evoked response waveform variation associated with recurrent otitis media, $315(\mathrm{My})$

Lenis A see Ruff $T$

Lessard M-L, Daniel RK: Surgical anatomy of septorhinoplasty, 25 (Ja)

Lesser RW, Spector JG: Facial nerve palsy associated with Warthin's tumor, 548 (Au)

Levine JL: Ventilating tubes (letter) 416 (Je)

Levine PA: Reconstruction of large nasal defects with subcutaneous pedicle nasolabial flap, 628 (Se)

Levine S see Broniatowski M

Lewy RB: Twisted larynx (letter) 557 (Au)

Libby DH see Schuller DE

Lim RY: Laser arytenoidectomy, 262 (Ap)

Lingeman RE see Zeph RD

Litt $M$ see Brown DT

Little FB Jr: Resident's page, 346 (My)

Lopchinsky RA see Vitug AC

Loubeau JM see Ryan JR

Lovett EJ III see Wolf GT

Lowrie C see Cinberg JZ

Lygizos NA see Hill JH

Lynn GE see Verma NP

\section{M}

Maceri DR, Lampe HB, Makielski KH, Passaman PP, Krause CJ: Conservation laryngeal surgery, 361 (Je)

Mackey-Hargadine JR see Hall JW III

Mafee MF see Deutsch EC; Hall JH

Magielski JE see Holtz F

Magnuson B see Hergils

Mahieu HF, Rosingh HJ, Saene RKFV, Schutte

HK: Deterioration of voice prostheses caused

by fungal vegetations (letter) 280 (Ap)

Mainland JF see Freeman P

Makielski KH see Maceri DR

Mäkinen J see Palva $\mathrm{T}$
Malaponte G see Denaro A

Malmgren LT see De Vito MA

Mancuso AA see Stevens MH

Mann WJ, Gilsbach J, Seeger W, Flöel H: Use of malar bone graft to augment skull-base access, 30 (Ja)

Maravilla KR see Schaefer SD

Marks JE, Smith PG, Sessions DG: Pharyngeal wall cancer, $79(\mathrm{Fe})$

Marmer J see Ryan JR

Marshak G see Ophir D

Marvin A see Lanser $M J$

Mathog RH see Godoy $J$

Mathog RH, Ragab MA: Temporalis muscle-galea

flap in facial reanimation, $168(\mathrm{Mr})$

Matsunaga RS: Westernization of Asian eyelid $149(\mathrm{Mr})$

Maupin G see Larrabee WF Jr

Maves MD see Mendez P Jr

Mayernik DG see Johnson JT

Mazzarino MC see Denaro A

McCaffrey TV see Ellis JC

McCaughan JS Jr see Schuller DE

McCollough EG see Webster RC

McCollough EG, English JL: New twist in nasa tip surgery, $524(\mathrm{Au})$

McGovern FH: Facial nerve meeting in Bordeaux (letter) 349 (My)

McIntosh WA, Kassner GW, Murray JF: Fibromatosis and fibrosarcoma of larynx and pharynx in infant, $478(\mathrm{Jy})$

Meirose RJ see Handlers JP

Meltzer $\mathrm{J}$ see Reed $\mathrm{HT}$

Mendez P Jr, Maves MD, Panje WR: Squamous cell carcinoma of head and neck in patients under 40 years of age, 762 (No)

Merkel MA see Schaefer SD

Merwin WH Jr, Barnes L, Myers EN: Unilocular cystic sebaceous lymphadenoma of parotid gland, 273 (Ap)

Meyers WG see Fisher SR

Michaels L see Robbins KT; Woodson GE

Mickel RA see Kessler DJ

Middleton WG see Forte $V$

Mills SE: Resident's page, 66 (Ja)

Milo GG see Schuller DE

Mohr RM see Fung RQ

Moon J see Weinberg $B$

Moore PJ, Pernoll ML, Norris CH, Shea JJ III, Barrilleaux CN, Tabb HG: Auditory evoked potential alterations induced by pulsed ultrasound, 309 (My)

Moorthy SS, Krishna G, Elliott CL: Is there an auriculovagal reflex producing cardiac dysrhythmias? (letter) 631 (Se)

Moran DT, Jafek BW, Rowley JC III, Eller PM: Electron microscopy of olfactory epithelia in 2 patients with anosmia, $122(\mathrm{Fe})$

Moran WB see Orr WC

Moran WB, Orr WC: Diagnosis and management of obstructive sleep apnea, $650(\mathrm{Oc})$

Morizono T, Giebink GS, Paparella MM, Sikora MA, Shea D: Sensorineural hearing loss in experimental purulent otitis media due to Streptococcus pneumoniae, 794 (De)

Morris JR see Coker NJ

Moscicki JC see Ruth RA

Murray JF see Mclntosh WA

Myer CM III, Reilly JS: Airway obstruction in immunosuppressed child, 409 (Je)

Myers EM, Hall MG Jr: Autograft frontoplasty, 626 (Se)

Myers EN see Johnson JT; Merwin WH Jr

Myers EN: Diseases of Nose, Throat, Ear, Head, and Neck (Book Review) 830 (De)

$$
\mathbf{N}
$$

Nakashima T, Kimmelman CP, Snow JB Jr: Olfactory marker protein in human olfactory pathway, 294 (My)

Neblett CR see Coker NJ 
Nedzelski JM: Advances in Audiology (Book Review) 561 (Au)

Neel HB III: Biomaterials in Otology (Book Review) 420 (Je)

Neely JG: Clinical Otoscopy (Book Review) 564 $\mathrm{Au})$

Neumann-Haefelin D see Ikenberg $H$

Newman A see Rice DH

Nieto CS, Garcia PB, Gomis JE, Garcia MJS: Survival of myocutaneous flaps, 43 (Ja)

Nishijima W, Tokita N, Watanabe I, Takooda S: Intramuscular myxoma of neck, 699 (Oc)

Nolan TA see Johnson JT

Norris CH see Moore PJ; Reed HT

Norris JEC see Conley $J$

Norton KJ see Silverman DG

Noyek AM: Head and Neck Imaging, Excluding Brain (Book Review) 418 (Je)

Nunnally R see Schaefer SD

0

O'Fallon WM see DeSanto LW

O'Sullivan TJ, Healy GB: Complications of Venturi jet ventilation during microlaryngeal surgery, $127(\mathrm{Fe})$

OIson JE see Barrs DM

Olsson I see Åsbrink E

Ophir D, Shapira A, Marshak G: Total inferior turbinectomy for nasal airway obstruction. 93 (Fe)

Orr WC see Moran WB

Orr WC, Moran WB: Diagnosis and management of obstructive sleep apnea, 583 (Se)

Osguthorpe JD: Allergy and immunology training in otolaryngology residency programs, 779 (De)

Osguthorpe JD: Osteoblastoma (letter) 208 (Mr)

Ow EP see Puczynski MS

$\mathbf{P}$

Palva T, Lehto V-P, Johnsson L-G, Virtanen I, Mäkinen J: Large cholesterol granuloma cysts in mastoid, clinical and histopathologic findings, 786 (De)

Panendoscopy Study Group see Leipzig B

Panje WR see Haughey BH; Mendez P Jr

Panje WR: Mandible reconstruction with trapezius osteomusculocutaneous flap, 223 (Ap)

Panje WR, Kitt VV: Tracheal stoma reconstruction, $190(\mathrm{Mr})$

Paparella MM see Morizono T

Paparella MM: Ultrastructural Atlas of Inner Ear (Book Review) 420 (Je)

Parkin JL see Stevens MH

Parkin JL: Introductory Workbook for CT of

Head and Neck (Book Review) 418 (Je)

Parnes SM see Koltai PJ

Pasic TB, Poulton TJ: Hospital-based helicopter $507(\mathrm{Au})$

Passamani PP see Maceri DR; Roa RA

Pearlman RC, Skinner HG, Pierce JD, Goins MA III: Reliability of sound-generating otoscope, 792 (De)

Pensak ML see Glasscock ME II

Pernoll ML see Moore PJ

Perry DA see Dierks EJ

Peterson KA see Wolf GT

Petruson B see Karlsson G

Pfister H-W see Einhaeupl $\mathrm{K}$

Pien FD see Bello EF

Pierce JD see Pearlman RC

Pillsbury HC III see Poole MD

Pinckers AJLG see Cremers CWRJ

Pitcock JK see Kearns DB

Plocher DW: Auditory response to inverted posture (letter) $135(\mathrm{Fe})$

Podoshin L see Fradis $M$
Poole MD, Pillsbury HC III: Prostaglandins and other metabolites of arachidonic acid, 317 (My)

Potsic WP see Brown DT

Poulton TJ see Pasic TB

Powell W see Davis 0

Price JC see Koltai PJ

Puczynski MS, Ow EP, Rust C: Cardiopulmonary arrest due to misuse of viscous lidocaine, 768 (No)

Puthawala AA, Syed AMN, Gates TC: Iridium192 implants in treatment of tonsillar region malignancies, $812(\mathrm{De})$

Putzeys R see Leipzig B

Quine DB see Reed HT

Quinn FB: Essentials of Otolaryngology (Book Review) 350 (My)

Ragab MA see Mathog RH

Rauch SD: Medial orbital blow-out fracture with entrapment, $53(\mathrm{Ja})$

Reardon EJ see Sillman JS

Reed HT, Meltzer J, Crews P, Norris CH, Quine DB, Guth PS: Amino-oxyacetic acid as palliative in tinnitus, 803 (De)

Reilly JS see Myer CM III

Reiner B see Fradis $M$

Remsen $K$ see Surkin $M$

Ricci A Jr see Zarbo RJ

Rice DH, Burstein FD, Newman A: Use of polytetrafluorinated ethylene compound in peripheral nerve grafting, 259 (Ap)

Rich JS see Schwenzfeier CW

Richardson GS: Peritonsillar abscess (letter) 135 ( $\mathrm{Fe}$ )

Richthammer B see Ikenberg H

Ridings EO see Roa RA

Rinehart JJ see Schuller DE

Ritter FN: Computed Tomography of Head and Neck (Book Review) 417 (Je)

Riveras E see Hagan WE

Roa RA, Carey TE, Passamani PP, Greenwood JH, Hsu S, Ridings EO, Schwartz DR, Wolf GT, Hudson JL: DNA content of human squamous cell carcinoma cell lines, 565 (Se)

Robbins KT see Woodson GE

Robbins KT, Michaels L: Feasibility of subtotal laryngectomy based on whole-organ examination, $356(\mathrm{Je})$

Robertson MS, Robinson JM: Pharyngoesophageal reconstruction, 375 (Je); (letter) 706 (Oc)

Robinson JM see Robertson MS

Rock RP see Schuller DE

Ronis ML see Fung RQ

Rosenbaum AE see Kennedy DW

Rosenbaum FA see Cinberg JZ

Rosenblum BN see Friedman WH

Rosingh HJ see Mahieu HF

Rossi M see Denaro A

Rowley JC III see Moran DT

Roy RC, Weeks DB: Otolaryngologists using local anesthetics containing epinephrine (letter) $280(\mathrm{Ap})$

Ruff T, Lenis A, Diaz JA: Atypical facial pain and orbital cancer, 338 (My)

Rumore GJ see Tami TA

Rust C see Puczynski MS

Ruth RA, Gal TJ, DiFazio CA, Moscicki JC: Brain-stem auditory-evoked potentials during lidocaine infusion in humans, 799 (De)

Ryan JR, loachim HL, Marmer J, Loubeau JM: Acquired immune deficiency syndrome-related lymphadenopathies presenting in salivary gland lymph nodes, 554 (Au)
Sachs ME: Enbucrilate as cartilage adhesive in augmentation rhinoplasty, 389 (Je)

Saene RKFV see Mahieu HF

Salamonsen RF see Freeman P

Sasaki CT: Applied Anatomy and Physiology of Speech and Hearing Mechanisms (Book Review) 419 (Je)

Scaf JJ see Cremers CWRJ

Schaefer SD, Henderson AH, Glover ED, Christen AG: Patterns of use and incidence of smokeless tobacco consumption in school-age children, $639(\mathrm{Oc})$

Schaefer SD, Maravilla KR, Suss RA, Burns DK, Nunnally R, Merkel MA, Close LG: Magnetic resonance imaging vs computed tomography, $730(\mathrm{No})$

Schild JA see Deutsch EC

Scholl P see Beall J

Schramm VL Jr see Johnson JT

Schroeder W, Gnepp DR: Resident's page, 772 (No)

Schuknecht HF: Temporal bone findings in otopalatodigital syndrome (editorial footnote) 121 (Fe)

Schuller DE:

Dysphagia (Book Review) 419 (Je)

Reconstructive options for pharyngeal and/or cervical esophageal defects, $193(\mathrm{Mr})$

Schuller DE, Libby DH, Rinehart JJ, Milo GG, Koolemans-Beynen A: Immunomodulation of nodal lymphocytes in head and neck cancer, 465 (Jy)

Schuller DE, McCaughan JS Jr, Rock RP: Photodynamic therapy in head and neck cancer, 351 (Je)

Schutte HK see Mahieu HF

Schwartz DR see Roa RA

Schwenzfeier CW, Emerson E, Rich JS: Resident's page, 412 (Je)

Sciubba JJ see Barat $M$

Sebek B see Broniatowski $M$

Seeger W see Mann WJ

Seigler HF see Fisher SR

Selkin SG: Laser turbinectomy as adjunct to rhinoseptoplasty, 446 (Jy)

Sessions DG see Marks JE

Shah JP see Vikram B

Shaia FT see Lenhardt ML

Shapira A see Ophir D

Shapiro BM see Jay J

Shea D see Morizono T

Shea JJ III see Horn KL; Moore PJ

Shea JJ see Yazawa $Y$

Shi S-R: Temporal bone findings in case of otopalatodigital syndrome, $119(\mathrm{Fe})$

Shoss SM, Donovan DT, Alford BR: Tumors of parapharyngeal space, 753 (No)

Sigler BA see Johnson JT

Sikora MA see Morizono T

Sillman JS, Eavey RD, Reardon EJ, Thornton AR:

Metabolic facial paralysis in infant, 822 (De)

Silva EG see Kraemer BB

Silverman DG, Weinstock BS, Brousseau DA, Norton KJ, Kniffin SA, Smith G: Comparative assessment of blood flow to canine island flaps, 677 (Oc)

Silverman PM: Medullary space involvement in laryngeal carcinoma, 541 ( $\mathrm{Au})$

Simmons FB: Lidocaine in treatment of Meniere's disease (letter) 829 (De)

Singer MI see Blom ED; Hamaker RC

Sisson GA see Atiyah RA; Wurster CF

Skinner HG see Pearlman RC

Smith G see Silverman DG

Smith PG see Marks JE

Smith RC see Webster RC

Snow JB Jr see Nakashima T

Snyderman NL see Leipzig B

Soboroff BJ see Hill JH 
Som $P$ see Surkin $M$

Souliere CR Jr, Kirchner JA: Laryngeal perichon-

dritis and abscess, 481 (Jy)

Spector JG see Lesser RW

Spiro RH see Vikram B

Sridhar S see Vitug AC

Srigley JR see Kraemer BB

Srodes CH see Johnson JT

Stegnjajic A, Wenig BL, Guberina L, Abramson

AL: Glottic reconstruction with thyroid peri-

chondrium and investing cervical fascia, 472 (Jy)

Steinberg B see Abramson AL

Stevens MH, Harnsberger HR, Mancuso AA, Davis RK, Johnson LP, Parkin JL: Computed tomography of cervical lymph nodes, 735 (No)

Stewart FM see Kaplan MJ

Stiernberg C: Current Therapy in Otolaryngology-Head and Neck Surgery 1984-1985 (Book Review) 490 (Jy)

Stiernberg CM: Pectoralis myocutaneous flap modifications (letter) $208(\mathrm{Mr}$ )

Strong EW see Vikram B

Suen JY see Leipzig B

Surkin M, Remsen K, Lawson W, Som P, Biller

HF: Mucocele of submandibular gland, 623 (Se)

Suss RA see Schaefer SD

Sutton D see Larrabee WF Jr

Swanson NA see Baker SR

Sweetow R: Counseling patient with tinnitus, $283(\mathrm{My})$

Sweetow RW: Management of patients with tinnitus (letter) 631 (Se)

Syed AMN see Puthawala AA

\section{$\mathbf{T}$}

Tabb HG see Moore PJ

Takahara $T$ see Doyle WJ

Takooda $S$ see Nishijima $W$

Tami TA, Rumore GJ: Resident's page, 204 (Mr)

Tanabe $M$ see Honjo I

Tanabe $\mathbf{M}$, Honjo I, Isshiki N: Neoglottic reconstruction following total laryngectomy, 39 ( Ja)

Tanaka S see Honjo I

Tardy-Mitzell S, Andrews ML, Bowman SA: Acceptability and intelligibility of tracheoesophageal speech, $213(\mathrm{Ap})$

Terasawa $R$ see Hirano $M$

Terr LI, Edgerton BJ: Three-dimensional reconstruction of cochlear nuclear complex in humans, 495 (Au)

Thearle PB see Johnson JT

Theunissen E see Cremers C

Thomas JR:

Aesthetic facial surgery in otolaryngology training program, $141(\mathrm{Mr})$

Atlas of Skin Repair (Book Review) 564 (Au)
Thornton AR see Sillman JS

Tinsley PP Jr see Conley J

Todd NW Jr, Bowman CA: Otitis media at Canyon Day, Ariz, 606 (Se)

Tokita $\mathbf{N}$ see Nishijima $\mathbf{W}$

Tomoda $K$ see Yamashita $T$

Trachy RE see Cummings CW

Tucker HM see Bronaitowski M

Tucker HM, Broniatowski M, Chase S: Tube esophagostomy, $187(\mathrm{Mr})$

\section{$\mathbf{U}$}

Urken $M$ see Biller HF

\section{Valvassori GE see Applebaum EL}

Van Kirk $M$ see Holt JE

Vartiainen E, Karjalainen S: Surgery in elderly patients with chronic otitis media, 509 (Au)

Verma NP, Lynn GE: Auditory evoked responses in multiple sclerosis, 22 (Ja)

Vikram B, Strong EW, Shah JP, Spiro RH: Irradiation after neck dissection (letter) 827 (De)

Virtanen I see Palva T

Vitug AC, Lopchinsky RA, Sridhar S, Wheeler MF, Goldman JM: Tracheal carcinoma presenting as thyroid cyst, 340 (My)

Volkers WS see Cremers CWRJ

w

Wagner RL see Johnson JT

Walike JW, Larrabee WF Jr: 'Note flap', 430 (Jy)

Walker AN, Etheridge JG, Griffin WL: Resident's page, 276 (Ap)

Walker AN, Jones PF: Resident's page, 702 (Oc)

Walter RJ, Danielson JR: Defective monocyte chemotaxis in patients with epidermoid tumors of head and neck, $538(\mathrm{Au})$

Wang L, Karmody CS: Dysphagia as presenting symptom of tetanus, 342 (My)

Ward CF: Otolaryngologists using local anesthetics containing epinephrine (letter) 281 (Ap)

Watanabe I see Nishijima W

Waterman J see Handlers JP

Watson JB see Williams SE

Webster RC see Koranda FC

Webster RC, McCollough EG, Giandello PR, Smith RC: Skin wound approximation with new absorbable suture material, 517 (Au)

Weeks DB see Roy RC

Weinberg B, Moon J: Tracheoesophageal puncture prostheses (letter) $209(\mathrm{Mr})$

Weingarten $\mathbf{C}$ see Keller GS

Weinstock BS see Silverman DG

Weisberger EC see Zeph RD
Welsh R, Bratcher GO, Cotton RT: Resident's page, 558 ( $\mathrm{Au}$ ); correction, 708 (No)

Wenig BL see Stegnjajic A

Wesson $K$ see Wetmore $S$ J

Wetmore SJ see Leipzig B

Wetmore SJ, Krueger K, Wesson K, Blessing ML: Long-term results of Blom-Singer speech rehabilitation procedure, $106(\mathrm{Fe})$

Wheeler MF see Vitug AC

Williams SD see Zeph RD

Williams SE, Watson JB: Differences in speaking proficiencies in 3 laryngectomee groups, 216 (Ap)

Willis CR see Greenblatt D

Wilson J: Deafness in developing countries, 2 (Ja)

Winkler B see Abramson AL

Wolf GT see Roa RA

Wolf GT: Head and Neck Surgery (Book Review) 633 (Se)

Wolf GT, Amendola BE, Diaz R, Lovett EJ III, Hammerschmidt RM, Peterson KA: Definite vs adjuvant radiotherapy, 716 (No)

Wolfart W see Ikenberg $H$

Wolff AP see Davis $O$

Woodson GE, Robbins KT, Michaels L: Inverted papilloma, 806 (De)

Wurster CF see Atiyah RA

Wurster CF, Krepsi YP, Davis JW, Sisson GA: Combined functional oral rehabilitation after radical cancer surgery, $530(\mathrm{Au})$

\section{Y}

Yamashita T, Ino C, Tomoda K, Kumazawa T: Prognostic determination and submandibular function in Bell's palsy, 244 (Ap)

Yazawa Y, Shea JJ, Kitahara M: Endolymphatic hydrops in guinea pigs after cauterizing sac with silver nitrate, 301 (My)

Yeh S see Davis 0

Yim DWS see Burgess LPA

Zarbo RJ, Ricci A Jr, Kowalczyk PDH, Cartun RW, Knibbs DR: Intranasal dermal analogue tumor (membranous basal cell adenoma) 333 (My)

Zee DS: Perspectives on pharmacotherapy of vertigo, 609 (Se)

Zellmer JE see Leipzig B

Zemplenyi J, Calcaterra TC: Chondrocalcinosis of temporomandibular joint, 403 (Je)

Zeph RD, Weisberger EC, Einhorn LH, Williams SD, Lingeman RE: Modified neck dissection for metastatic testicular carcinoma, 667 (Oc)

Zinny MA see Greenblatt DJ

Zinreich SJ see Kennedy DW

zur Hausen $\mathbf{H}$ see Ikenberg $\mathbf{H}$

Zuckerbraun L see Castro D 


\section{SUBJECT INDEX TO VOLUME 111}

The following Index is an alphabetical list of significant subjects presented in this volume. Books reviewed are listed alphabetically by first author under the heading "BOOK REVIEWS."

\section{A}

\section{Abnormalities, Multiple}

complete mandibular agenesis [Brecht] $132(\mathrm{Fe})$ Abscess

laryngeal perichondritis and [Souliere] $481(\mathrm{Jy})$ neck, Salmonella dublin [Bello] 476 (Jy)

peritonsillar (letter) [Richardson] 135 (Fe)

tuberculous petrous apicitis [Kearns] 406 (Je)

Absorptiometry, Photon see Radionuclide Imag-

ing

Absorption, Skin see Skin Absorption

Acetic Acids

amino-oxyacetic acid as palliative in tinnitus [Reed] $803(\mathrm{De})$

Acoustic Impedance Tests

morning pressure in middle ear [Hergils] 86 (Fe)

Acoustic Trauma see Hearing Loss, NoiseInduced

Acquired Immunodeficiency Syndrome

Kaposi's sarcoma in patient with, residerit's page [Lanser] 486 (Jy)

related lymphadenopathies presenting in salivary gland lymph nodes [Ryan] 554 (Au)

Actins

cytoskeletal proteins in oncocytic tumors of parotid gland [Gustafsson] 99 (Fe)

Acupuncture

auricular perichondritis secondary to [Davis] 770

(No)

Adenitis see Lymphadenitis

Adenoidectomy

diagnosis and management of obstructive sleep apnea, II. [Moran] 650 (Oc)

nasopharyngeal stenosis [Cotton] $146(\mathrm{Mr})$

\section{Adenoids}

airway obstruction in immunosuppressed child [Myer] 409 (Je)

pleomorphic adenoma, resident's page [Welch]

$558(\mathrm{Au})$; correction, 708 (No)

Adenolymphoma

cytoskeletal proteins in oncocytic tumors of parotid gland [Gustafsson] 99 (Fe)

facial nerve palsy associated with Warthin's tumor [Lesser] $548(\mathrm{Au})$

Warthin's tumor arising in lymph node containing heterotopic salivary gland, resident's page [Cannon] 702 (Oc)

Adenoma

benign, of middle ear, resident's page [Little] 346 (My)

cytoskeletal proteins in oncocytic tumors of parotid gland [Gustafsson] $99(\mathrm{Fe})$

oncocytoma of larynx, resident's page [Schwenzfeier] $412(\mathrm{Je})$

pleomorphic, and metastatic squamous cell carcinoma, resident's page [Atiyah] $204(\mathrm{Mr})$

pleomorphic, resident's page [Welsh] $558(\mathrm{Au})$; correction, 708 (No)

Adenoma, Basophilic

intranasal dermal analogue tumor (membranous basal cell adenoma), ultrastructure and immunohistochemistry [Zarbo] 333 (My)

Adhesives

enbucrilate as cartilage adhesive in augmentation rhinoplasty [Sachs] 389 (Je)

Administration, Oral

of lidocaine solution, lidocaine plasma concentrations following [Greenblatt] 298 (My)
Administration Schedule, Drug see Drug Administration Schedule

\section{Adrenal Cortex Hormones}

lateral sinus thrombosis, medical or surgical treatment? [Goldenherg] $56(\mathrm{Ja})$

Adrenaline see Epinephrine

Adrenergic Beta Receptor Blockaders

dangers of propranolol withdrawal prior to local anesthesia with epinephrine (letter) [Alexander] $280(\mathrm{Ap})$

otolaryngologists using local anesthetics containing epinephrine (letter) [Roy] 280, (reply) [Brummett] (letter) [Ward] 281 (Ap)

Advertising

give priceless gift this year [Bailey] 777 (De)

patterns of use and incidence of smokeless tobacco consumption in school-age children [Schaefer] 639 (Oc)

smokeless tobacco, open letter to Surgeon General [Bailey] 707 (No)

we must stop selling cancer to our children [Bailey] 637 (Oc)

AFP see Alpha Fetoproteins

Agar

immunomodulation of nodal lymphocytes in head and neck cancer [Schuller] 465 (Jy)

Age Factors

predicting response to tongue retaining device for sleep apnea syndrome [Cartwright] 385 (Je)

surgery in elderly patients with chronic otitis media [Vartiainen] 509 (Au)

Aging

pathogenesis of protruded false vocal fold [Honjo] 398 (Je)

Airway Obstruction

in immunosuppressed child [Myer] 409 (Je)

laser turbinectomy as adjunct to rhinoseptoplasty [Selkin] 446 (Jy)

nasal, total inferior turbinectomy for [Ophir] 93 (Fe)

Airway Resistance

laryngeal perichondritis and abscess [Souliere] $481(\mathrm{Jy})$

Alcohol Drinking

Warthin's tumor arising in lymph node containing heterotopic salivary gland, resident's page [Cannon] 702 (Oc)

Allergy and Immunology

role of allergy in pathogenesis of otitis media with effusion [Goyle] $502(\mathrm{Au})$

training in otolaryngology residency programs [Osguthorpe] $779(\mathrm{De})$

Allergy see Hypersensitivity

Alpha Fetoproteins

modified neck dissection for metastatic testicular carcinoma [Zeph] 667 (Oc)

American Academy of Facial Plastic and Reconstructive Surgery

meeting, Las Vegas, September 1984, papers read before, 142-203 (Mr) 421-464 (Jy)

American Board of Otolaryngology

allergy and immunology training in otolaryngology residency programs [Osguthorpe] 779 (De)

American National Standards Institute

reliability of sound-generating otoscope [Pearlman] 792 (De)

American Society for Head and Neck Surgery

meeting, Dorado Beach, Puerto Rico, May 8, 1985,
Am. Society of Head and Neck Surgerypapers read before, 709-762 (No)

Aminooxyacetic Acid see Acetic Acids

Ainnion

oral cavity reconstruction using pectoralis major muscle and [Lawson] 230 (Ap)

Amyloid

localized deposit (amyloidoma) of tonsil, resident's page [Davis] 412 (Je)

Anaerobiosis see Metabolism

Anesthetics, Local

containing epinephrine, otolaryngologists using

(letter) [Roy] 280, (reply) [Brummett] (letter)

[Ward] 281 (Ap)

with epinephrine, dangers of propranolol withdrawal prior to (letter) [Alexander] 280 (Ap)

\section{Aneurysm}

posttraumatic pseudoaneurysm of extracranial middle meningeal artery [Jay] 264 (Ap)

Aneurysm, Arteriovenous, Congenital see Arteriovenous Malformations

Aneurysm, Arteriovenous, Congenital, Cerebra see Cerebral Arteriovenous Malformations

Angiography

tumors of parapharyngeal space [Shoss] 753 (No)

Angioma, Sclerosing

chemotherapy for aggressive juvenile nasopharyngeal angiofibroma [Goepfert] 285 (My)

dynamic computed tomography, assessment of vascular malformations and angiofibroma [Hill] $62(\mathrm{Ja})$

Ankylosis

stapes, proximal symphalangia [Cremers] 765 (No)

Anosmia

electron microscopy of olfactory epithelia in 2 patients with [Moran] $122(\mathrm{Fe})$

Anoxemia

diagnosis and management of obstructive sleep apnea, multidisciplinary approach [Orr] 583 (Se)

Anti-Arrhythmia Agents

brain-stem auditory-evoked potentials during lidocaine infusion in humans [Ruth] 799 (De)

Antibiotic-Associated Colitis see Enterocolitis,

Pseudomembranous

Antibiotics

Lyme disease, cause of bilateral facial paralysis [Glasscock] 47 (Ja)

Antibodies

auricular perichondritis secondary to acupuncture [Davis] 770 (No)

Antibody Deficiency Syndrome see Immunologic Deficiency Syndromes

Antigen-Antibody Complex

circulating immunocomplexes and laryngeal carcinoma [Denaro] 595 (Se)

Antigens

role of allergy in pathogenesis of otitis media with effusion [Doyle] $502(\mathrm{Au})$

Antilymphocyte Serum see Immunosuppression

Antineoplastic Agents

chemotherapy for aggressive juvenile nasopharyngeal angiofibroma [Goepfert] $285(\mathrm{My})$

Apnea, Central see Sleep Apnea Syndromes

Apnea, Obstructive see Sleep Apnea Syndromes

Apnea, Sleep see Sleep Apnea Syndromes

Apocrine Glands see Sweat Glands 
Arachidonic Acids

prostaglandins and other metabolites of [Poole] 317 (My)

Arrythmia

lidocaine plasma concentrations following administration of intraoral lidocaine solution [Greenblatt] $298(\mathrm{My})$

Arteriography see Angiography

Arteriovenous Aneurysm, Congenital see Arteriovenous Malformations

Arteriovenous Aneurysm, Congenital, Cerebra see Cerebral Arteriovenous Malformations

Arteriovenous Malformations

dynamic computed tomography, assessment of vascular malformations and angiofibroma [Hill] 62 (Ja)

Arteriovenous Malformations, Cerebral see Cerebral Arteriovenous Malformations Arytenoid Cartilage see Laryngeal Cartilages

Asia

westernization of Asian eyelid [Matsunaga] 149 (Mr)

\section{Audiometry}

auditory capabilities of single-channel cochlear implant patients, etiologic considerations [Edgerton] 255 (Ap)

auditory evoked responses in multiple sclerosis, wave 1 abnormality (Verma) 22 (Ja)

brain-stem auditory-evoked potentials during lidocaine infusion in humans [Ruth] 799 (De)

electrocochleography and symptoms of inner ear dysfunction [Ferraro] $71(\mathrm{Fe})$

hearing acuity of children with otitis media with effusion [Fria] $10(\mathrm{Ja})$

reliability of sound-generating otoscope [Pearlman] $792(\mathrm{De})$

temporal bone findings in otopalatodigital syndrome [Shi] $119(\mathrm{Fe})$

$\mathrm{X}$-linked progressive mixed deafness with perilymphatic gusher during stapes surgery [Cremers] 249 (Ap)

Audiometry, Electroencephalic Response see Audiometry, Evoked Response

Audiometry, Evoked Response see Audiometry

Audiometry, Impedance see Acoustic Impedance Tests

Auditory Canal, External see Ear Canal

Auditory Evoked Potentials see Evoked Potentials, Auditory

Auditory Ossicles see Ear Ossicles

Auditory Prosthesis

auditory capabilities of single-channel cochlear implant patients, etiologic considerations [Edgerton] $255(\mathrm{Ap})$

Autoantigens see Antigens

Autograft see Transplantation, Autologous

Autotransplant see Transplantation, Autologous

nerve grafting, functional results after primary vs delayed repair [Ellis] $781(\mathrm{De})$

Bacillus Calmette Guerin Vaccine see BCG Vaccine

Basal Cell Nevus Syndrome see Carcinoma, Basal Cell

Basilar Membrane see Labyrinth

BCG Vaccine

innmunomodulation of nodal lymphocytes in head and neck cancer [Schuller] 465 (Jy)

Biell's Palsy see Facial Paralysis

Bliocompatible Materials

injectable liquid silicone (letter) [Aronsohn] (reply) [Kamer] 70 (Ja)

prorous polyethylene in reconstructive head and neck surgery [Berghaus] $154(\mathrm{Mr})$

Btiomaterials see Biocompatible Materials

Bilepharoptosis

bilepharoplasty, indications and preoperative assessment [Holt] $394(\mathrm{Je})$
Blood

lidocaine plasma concentrations following administration of intraoral lidocaine solution [Greenblatt] 298 (My)

\section{Blood Flow Velocity}

comparative assessment of, to canine island flaps

[Silverman] $677(\mathrm{Oc})$

measurement of alternative blood flow in porcine panniculus carnosus myocutaneous flap [Cummings] 598 (Se)

Blood Platelets

prostaglandins and other metabolites of arachidonic acid [Poole] 317 (My)

\section{Blood Vessels}

prostaglandins and other metabolites of arachidonic acid [Poole] $317(\mathrm{My})$

Blunt Injuries see Wounds, Nonpenetrating

Bone and Bones

mandible reconstruction with trapezius osteomusculocutaneous flap [Panje] 223 (Ap)

medullary space involvement in laryngeal carcinoma, computed tomographic demonstration [Silverman] $541 \mathrm{(Au})$

osteogenesis in vascularized periosteum, interactions with underlying bone [Canalis] $511(\mathrm{Au})$

trapezius osteomyocutaneous flap for mandibu-

lar reconstruction [Gregor] $198(\mathrm{Mr})$

Bone Conduction

congenital cholesteatoma of petrous pyramid [Horn] 621 (Se)

hearing acuity of children with otitis media with effusion [Fria] $10(\mathrm{Ja})$

Bone Plates

mandibular reconstruction with A-O plate [Hilg er] 469 (Jy)

Bone Tuberculosis see Tuberculosis, Osteoarticular

BOOK REVIEWS

Bailey BJ, ed: Surgery of Larynx, 776 (No)

Ballenger JJ: Diseases of Nose, Throat, Ear Head, and Neck, 830 (De)

Bateman HE, Mason RM: Applied Anatomy and Physiology of Speech and Hearing Mechanism 419 (Je)

Becker W, Buckingham RA, Holinger PH, et al: Atlas of Ear, Nose and Throat Diseases, Including Bronchoesophagology, 418 (Je)

Bergeron RT, Osborn AG, Som PM, eds: Head and Neck Imaging, Excluding the Brain, 418 (Je)

Carter BL, ed: Computed Tomography of Head and Neck, 417 (Je)

Cummings CW, Sessions DG, Weymuller EA Jr, Wood P: Atlas of Laryngeal Surgery, 561 (Au)

Friedmann I, Ballantyne J: Ultrastructural Atlas of Inner Ear, 420 (Je)

Gates GA, ed: Current Therapy in Otolaryngology-Head and Neck Surgery, 1984-1985, 490 (Jy)

Glattke TJ: Short-Latency Auditory Evoked Potentials: Fundamental Bases and Clinical Applications, 490 (Jy)

Groher ME: Dysphagia, Diagnosis and Management, 419 (Je)

Grote JJ, ed: Biomaterials in Otology, 420 (Je)

Hanafee W, Mancuso A: Introductory Workbook for CT of Head and Neck, 418 (Je)

Hawke M, Keene M, Alberti PW: Clinical Otoscopy, Text and Colour Atlas, $564(\mathrm{Au})$

Kahane JC, Folkins JF: Atlas of Speech and Hearing Anatomy, 633 (Se)

Keidel WD, Finkenzeller P, eds: Advances in Audiology, 561 (Au)

Lim DJ, et al, eds: Recent Advances in Otitis Media with Effusion, 563 (Au)

Lucente FE, Sobol SM: Essential of Otolaryngology, 350 (My)

Naumann $\mathrm{HH}$, ed: Head and Neck Surgery, Indications, Techniques, Pitfalls, 633 (Se)

Northern JL: Hearing Disorders, 419 (Je)
Book Reviews - Continued

Regnault P, Daniel RK: Aesthetic Plastic Surgery, $417(\mathrm{Je})$

Sasaki CT, et al: Skull Base Surgery, 562 (Au)

Serafin D, Georgiade NG: Pediatric Plastic Surgery, $490(\mathrm{Jy})$

Shaheen OH: Problems in Head and Neck Surgery, $563(\mathrm{Au})$

Stahle J, ed: Vestibular System, Fundamental and Clinical Observations, 562 (Au)

van der Waal I, Snow GB, eds: Oral Oncology, 417 (Je)

Zoltan J: Atlas of Skin Repair, 564 (Au)

Bowen's Disease see Carcinoma, Squamous Cell

Brain

rhinocerebral mucormycosis, resident's page [Walker] 276 (Ap)

Brain Death

auditory brain-stem response in determination of [Hall] $613(\mathrm{Se})$

Brain Neoplasms

primary CNS lymphoma in cerebellopontine angle [Ierokomos] $50(\mathrm{Ja})$

Brain Stem

auditory-evoked potentials during lidocaine infusion in humans [Ruth] 799 (De)

changing concepts of acoustic neuroma diagnosis [Barrs] 17 (My)

evoked response waveform variation associated with recurrent otitis media [Lenhardt] 315 (My)

response, auditory, in determination of brain death [Hall] 613 (Se)

3-dimensional reconstruction of cochlear nuclear complex in humans [Terr] 495 (Au)

Branchial Region

intraparotid branchial cleft cyst, resident's page [Tami] $204(\mathrm{Mr})$

Bronchial Neoplasms

interferon therapy for bronchial papillomatosis controlled by papillomavirus-DNA hybridization [Ikenberg] $96(\mathrm{Fe})$

Bronchoscopy

role of endoscopy in evaluating patients with head and neck cancer, multi-institutional prospective study [Leipzig] 589 (Se)

Burns, Electric

reconstruction of half of face [Conley] $142(\mathrm{Mr})$

\section{C}

Calmette Guerin Bacillus Vaccine see BCG Vaccine

Cancer see Neoplasms

Cancer Staging see Neoplasm Staging

Candidiasis

cardiopulmonary arrest due to misuse of viscous lidocaine [Puczynski] 768 (No)

Carbohydrates

study of mucus glycoproteins in secretory otitis media [Brown] 688 (Oc)

Carbon Dioxide

inhalation of mixtures of for sensorineural deafness, evaluation of rebreathing method [Freeman] $75(\mathrm{Fe})$

laser stapedotomy, thermal effects in vestibule [Coker] 601 (Se)

morning pressure in middle ear [Hergils] 86 (Fe)

Carcinoma

DNA flow cytometry of thyroid neoplasms [Kraemer] $34(\mathrm{Ja})$

mucoepidermoid, in pediatric age group, treatment and prognosis of [Conley] $322(\mathrm{My})$

patterns of use and incidence of smokeless tobacco consumption in school-age children [Schaefer] 639 (Oc)

Carcinoma, Basal Cell

oblique forehead flap for total reconstruction of nasal tip and columella [Baker] 425 (Jy) 
Carcinoma, Basal Cell-Continued

photodynamic therapy in otolaryngology-head and neck surgery [Keller] 758 (No)

reconstruction of large nasal defects with subcutaneous pedicle nasolabial flap, underutilized technique [Levine] 628 (Se)

trapdoor effect in nasolabial flaps, causes and corrections [Koranda] 421 (Jy)

Carcinoma, Epidermoid see Carcinoma, Squamous Cell

Carcinoma, Papillary

DNA flow cytometry of thyroid neoplasms [Kraemer] $34(\mathrm{Ja})$

Carcinoma, Squamous Cel

atypical facial pain and orbital cancer [Ruff] 338 (My)

cervical lymph node metastases, incidence and implications of extracapsular carcinoma [Johnson] 534 (Au)

cisplatin potentiation of radiotherapy, long-term follow-up [Leipzig] 114 (Fe)

combined functional oral rehabilitation after radical cancer surgery [Wurster] $530(\mathrm{Au})$

definite vs adjuvant radiotherapy, comparative effects on lymphocyte subpopulations in patients with head and neck squamous carcinoma [Wolf] 716 (No)

human, cell lines, DNA content of, analysis by flow cytometry and chromosome enumeration [Roa] 565 (Se)

immunomodulation of nodal lymphocytes in head and neck cancer [Schuller] 465 (Jy)

irradiation after neck dissection (letters) [Blitzer, Vikram] 827 (reply) [DeSanto] 828 (De)

maintenance chemotherapy for high-risk patients, preliminary report [Johnson] 727 (No)

metastatic, and pleomorphic adenoma, resident's page [Atiyah] $204(\mathrm{Mr})$

mitomycin and fluorouracil with concomitant radiotherapy in head and neck cancer [Kaplan] 220 (Ap)

near-total pharyngeal reconstruction by 'rotarydoor' sternohyoid myocutaneous flap in dog, preliminary report [Broniatowski] $673(\mathrm{Oc})$

neck dissection and combined therapy, study of effectiveness [DeSanto] 366 (Je)

oblique forehead flap for total reconstruction of nasal tip and columella [Baker] $425(\mathrm{Jy})$

of head and neck in patients under 40 years of age [Mendez] 762 (No)

oral lichen planus and squamous carcinoma, case report and literature update [Kaplan] 543 (Au)

role of endoscopy in evaluating patients with head and neck cancer, multi-institutional prospective study [Leipzig] 589 (Se)

tracheal, presenting as thyroid cyst [Vitug] 340 (My)

tumors of parapharyngeal space [Shoss] 753 (No)

Cardiac Arrest see Heart Arrest

Cardiopulmonary Arrest see Heart Arrest

Carotid Arteries

dynamic computed tomography, assessment of vascular malformations and angiofibroma [Hill] 62 (Ja)

Cartilage see also Laryngeal Cartilages

enbucrilate as cartilage adhesive in augmentation rhinoplasty [Sachs] 389 (Je)

intranasal composite grafts for dorsal support [Conley] 241 (Ap)

new twist in nasal tip surgery, alternative to Goldman tip for wide or bulbous lobule [McCollough] 524 (Au)

porous polyethylene in reconstructive head and neck surgery [Berghaus] 154 (Mr)

Cartilage, Articular

rabbit, use of buty]-2-cyanoacrylate in [Fung] 459 (Jy)

CAT Scan, X-Ray see Tomography, X-Ray Computed

\section{Catgut see Sutures}

Cats

carbon dioxide laser stapedotomy, thermal effects in vestibule [Coker] 601 (Se)

Cautery

endolymphatic hydrops in guinea pigs after cauterizing sac with silver nitrate [Yazawa] 301 (My)

Cell Line

DNA content of human squamous cell carcinoma analysis by flow cytometry and chromosome enumeration [Roa] 565 (Se)

Cephalometry

indications for palatopharyngoplasty [deBerry Borowiecki] 659 (Oc)

profile analysis in facial plastic surgery [Larrabee] 682 (Oc)

\section{Cephalosporins}

Clostridium difficile colitis following head and neck surgery, case reports [Griebie] $550(\mathrm{Au})$

Cerebellopontine Angle

primary CNS lymphoma in [Ierokomos] 50 (Ja)

Cerebral Aneurysm

dynamic computed tomography, assessment of vascular malformations and angiofibroma [Hill] $62(\mathrm{Ja})$

Cerebral Arteriovenous Malformations

dynamic computed tomography, assessment of vascular malformations and angiofibroma [Hill] $62(\mathrm{Ja})$

\section{Cerebrospinal Fluid Shunts}

lateral sinus thrombosis, medical or surgical treatment? [Goldenberg] 56 (Ja)

\section{Cervix Neoplasms}

modified neck dissection for metastatic testicular carcinoma [Zeph] 667 (Oc)

\section{Cheek}

extended palatal island mucoperiosteal flap [Gullane] $330(\mathrm{My})$

nodular fasciitis, resident's page [Fechner] 136 ( $\mathrm{Fe})$

'note flap' [Walike] $430(\mathrm{Jy})$

Cheek Bone see Zygoma

defective monocyte, in patients with epidermoid tumors of head and neck [Walter] 538 ( Au)

Child

otitis media at Canyon Day, Ariz, 16-year followup in Apache Indians [Todd] 606 (Se)

patterns of use and incidence of smokeless tobacco consumption in school-age children [Schaefer] 639 (Oc)

treatment and prognosis of mucoepidermoid carcinoma in pediatric age group [Conley] 322 (My)

we must stop selling cancer to our children [Bailey] 637 (Oc)

Chin see Mandible

Chinchilla

eustachian tube function in [Doyle] 305 (My)

Cholesteatoma

congenital, of petrous pyramid [Horn] 621 (Se)

Cholesterol

large, granuloma cysts in mastoid, clinical and histopathologic findings [Palva] 786 (De)

Chondrocalcinosis

of temporomandibular joint, parotid pseudotumor [Zemplenyi] 403 (Je)

\section{Chordoma}

chondroid variant of, resident's page [Fechner] $66(\mathrm{Ja})$

Chromosomes

enumeration,'DNA content of human squamous cell carcinoma cell lines, analysis by flow cytometry and [Roa] 565 (Se)

Chronic Disease

surgery in elderly patients with chronic otitis media [Vartiainen] $509(\mathrm{Au})$

Cicatrix

trapdoor effect in nasolabial flaps, causes and corrections [Koranda] $421(\mathrm{Jy})$
Cisplatin

high-dose, acute deafness as complication of

[Guthrie] 344 (My)

potentiation of radiotherapy, long-term follow-

up [Leipzig] $114(\mathrm{Fe})$

Citrovorum Factor

maintenance chemotherapy for high-risk patients, preliminary report [Johnson] 727 (No)

Classification

scale for evaluating results of rhinoplasty [Anderson] $520(\mathrm{Au})$

\section{Cleft Palate}

otitis media at Canyon Day, Ariz, 16-year followup in Apache Indians [Todd] 606 (Se)

study of mucus glycoproteins in secretory otitis media [Brown] 688 (Oc)

temporal bone findings in otopalatodigital syndrome [Shi] $119(\mathrm{Fe})$

Clonogenic Cell Assay, Tumor see Tumor Stem Cell Assay

Clostridium Enterocolitis see Entercolitis, Pseudomembranous

Cochlea

auditory brain-stem response in determination of brain death [Hall] 613 (Se)

auditory capabilities of single-channel cochlear implant patients, etiologic considerations [Edgerton] 255 (Ap)

auditory evoked potential alterations induced by pulsed ultrasound [Moore] 309 (My)

carbon dioxide laser stapedotomy, thermal effects in vestibule [Coker] 601 (Se)

3-dimensional reconstruction of cochlear nuclear complex in humans [Terr] $495(\mathrm{Au})$

Cochlear Aqueduct see Cochlea

Cochlear Duct see Cochlea

Cochlear Implant see Auditory Prosthesis

Cochlear Microphonic Potentials see Evoked Potentials, Auditory

Colitis, Pseudomembranous see Entercolitis, Pseudomembranous

Community Health Education see Health Education

Computerized Tomography, X-Ray see Tomography, X-Ray Computed

Computers

computer-based method of filing photographs and procedures [Allan] $178(\mathrm{Mr})$

profile analysis in facial plastic surgery [Larrabee] 682 (Oc)

\section{Conchae Nasales see Turbinates}

Congresses

facial nerve meeting in Bordeaux (letter) [McGovern] 349 (My)

Contrast Media

magnetic resonance imaging vs computed tomography, comparison in imaging oral cavity and pharyngeal carcinomas [Schaefer] 730 (No)

Corti's Organ see Organ of Corti

Corticoids see Adrenal Cortex Hormones

Corticosteroids see Adrenal Cortex Hormones

Counseling

management of patients with tinnitus (letter)

[Gates] 631 (reply) [Sweetow] 632 (Se)

patient with tinnitus [Sweetow] $283(\mathrm{My})$

Cranial Sinus Thrombosis see Sinus Thrombosis

Cricoid Cartilage see Laryngeal Cartilages

Cryosurgery

laser turbinectomy as adjunct to rhinoseptoplasty [Selkin] $446(\mathrm{Jy})$

Cyanoacrylate

butyl-2-, use of, in rabbit auricular cartilage [Fung] 459 (Jy)

Cystadenoma Lymphomatosum, Papillary see Adenolymphoma

Cystic Fibrosis

metabolic facial paralysis in infants [Sillman] 822 (De)

Cystoscopy

role of endoscopy in evaluating patients with 


\section{Cystoscopy-Continued}

head and neck cancer, multi-institutional prospective study [Leipzig] 589 (Se)

\section{Cysts}

branchial cleft, intraparotid, resident's page [Tami] $204(\mathrm{Mr})$

hidrocystoma of apocrine gland derivation, resident's page [Hagan] 772 (No)

large cholesterol granuloma, in mastoid, clinical and histopathologic findings [Palva] 786 (De)

laryngeal, of thyroid cartilage [Burgess] 826 (De)

mucocele of submandibular gland [Surkin] 623 (Se)

tracheal carcinoma presenting as thyroid cyst [Vitug] 340 (My)

unilocular cystic sebaceous lymphadenoma of parotid gland [Merwin] 273 (Ap)

Cytofluorometry, Flow see Flow Cytometry

Cytokeratin see Keratin

Cytomegaloviruses

prevention of hearing impairment from infection and ototoxic drugs [Catlin] 377 (Je)

Cytometry, Flow see Flow Cytometry

\section{Cytoplasm}

neuroendocrine carcinoma of skin (Merkel's cell tumor, trabecular carcinoma of skin), resident's page [Walker] $702(\mathrm{Oc})$

\section{Deafness}

acute, complication of high-dose cisplatin [Guthrie] 344 (My)

auditory capabilities of single-channel cochlear implant patients, etiologic considerations [Edgerton] $255(\mathrm{Ap})$

challenge to otolaryngology [Bailey] 1 (Ja)

in developing countries, approaches to global program of prevention [Wilson] 2 (Ja)

sensorineural, inhalation of carbon dioxide mixtures for, evaluation of rebreathing method [Freeman] $75(\mathrm{Fe})$

$\mathrm{X}$-linked progressive mixed, with perilymphatic gusher during stapes surgery [Cremers] 249 (Ap)

Deafness, Partial see Hearing Loss, Partial

Decompression

medial orbital blow-out fracture with entrapment [Rauch] 53 (Ja)

Deglutition

morning pressure in middle ear [Hergils] 86 (Fe)

\section{Deglutition Disorders}

angiofollicular lymphoid hyperplasia, hyaline vascular variant (giant lymph node hyperplasia [GLNH], Castleman's disease), resident's page [Schroeder] 772 (No)

dysphagia and Forestier's disease [Deutsch] 400 (Je)

dysphagia as presenting symptom of tetanus [Wang] $342(\mathrm{My})$

histoplasmosis of tonsil, resident's page [Davis] $558(\mathrm{Au})$

Kaposi's sarcoma in patient with AIDS, resident's page [Lanser] $486(\mathrm{Jy})$

tube esophagostomy, new technique in management of long-term swallowing disorders [Tucker] $187(\mathrm{Mr})$

\section{Desmin}

cytoskeletal proteins in oncocytic tumors of parotid gland [Gustafsson] $99(\mathrm{Fe})$

Developing Countries

deafness in, approaches to global program of prevention [Wilson] 2 (Ja)

Devices see Equipment and Supplies

Diabetes Mellitus

Salmonella dublin neck abscess [Bello] 476 (Jy)

Diagnosis

and management of obstructive sleep apnea, multidisciplinary
Diagnosis - Continued

approach [Orr] 583 (Se); II. [Moran] 650 (Oc)

auditory brain-stem response in determination of brain death [Hall] 613 (Se)

cervical mycobacterial lymphadenitis, medical vs surgical management [Castro] 815 (De)

Clostridium difficile colitis following head and neck surgery, case reports [Griebie] 550 (Au)

computed tomography of cervical lymph nodes, staging and management of head and neck cancer [Stevens] 735 (No)

functional endoscopic sinus surgery, theory and diagnostic evaluation [Kennedy] 576 (Se)

malignant salivary gland tumors of base of tongue [Kessler] 664 (Oc)

Meniere's disease (syndrome?) [Kohut] 494 (Au)

tumors of parapharyngeal space [Shoss] 753 (No)

Diagnosis, Differential

modified neck dissection for metastatic testicular carcinoma [Zeph] 667 (Oc)

Diffuse Idiopathic Skeletal Hyperostosis see Spinal Osteophytosis

Digestive System Neoplasms

pharyngoesophageal reconstruction using free jejunal interposition grafts [Fisher] 747 (No)

\section{Dipeptides}

immunomodulation of nodal lymphocytes in head and neck cancer [Schuller] $465(\mathrm{Jy})$

Diploidy

DNA content of human squamous cell carcinoma cell lines, analysis by flow cytometry and chromosome enumeration [Roa] 565 (Se)

\section{Disease}

inverted papilloma, considerations in treatment [Woodson] 806 (De)

\section{DNA}

content of human squamous cell carcinoma cel lines, analysis by flow cytometry and chromosome enumeration [Roa] 565 (Se)

flow cytometry of thyroid neoplasms [Kraemer] $34(\mathrm{Ja})$

interferon therapy for bronchial papillomatosis controlled by papillomavirus-DNA hybridization [Ikenberg] $96(\mathrm{Fe})$

verrucous carcinoma of larynx, possible human papillomavirus etiology [Abramson] 709 (No)

Dogs

calvarial grafts for midface rehabilitation [Cinberg] $434(\mathrm{Jy})$

comparative assessment of blood flow to canine island flaps [Silverman] $677(\mathrm{Oc})$

near-total pharyngeal reconstruction by 'rotarydoor' sternohyoid myocutaneous flap in, preliminary report [Broniatowski] 673 (Oc)

osteogenesis in vascularized periosteum, interactions with underlying bone [Canalis] 511 (Au) sensorineural hearing loss in experimental purulent otitis media due to Streptococcus pneumoniae [Morizono] 794 (De)

Doppler Effect see Physics

Doppler Uitrasound see Ultrasonics

Dose-Response Relationship, Radiation see Radiotherapy Dosage

Drainage

auricular perichondritis secondary to acupuncture [Davis] 770 (No)

tuberculous petrous apicitis [Kearns] 406 (Je)

wrestler's ear (acute auricular hematoma) (Giffin] $161(\mathrm{Mr})$

Drug Administration Schedule

perspectives on pharmacotherapy of vertigo [Zee] 609 (Se)

\section{Drug Hypersensitivity}

prevention of hearing impairment from infection and ototoxic drugs [Catlin] 377 (Je)

\section{Drug Therapy}

maintenance chemotherapy for high-risk patients, preliminary report [Johnson] 727 (No)

modified neck dissection for metastatic testicular carcinoma [Zeph] 667 (Oc)
Drug Therapy-Continued

perspectives on pharmacotherapy of vertigo [Zee] 609 (Se)

Dyes

survival of mycocutaneous flaps, experimental evaluation by intra-arterial injection of [Nieto] 43 (Ja)

Dysphagia see Deglutition Disorders

Dysphonia see Voice Disorders

\section{$\mathbf{E}$}

Ear.

surgery in elderly patients with chronic otitis media [Vartiainen] 509 (Au)

wrestler's, (acute auricular hematoma) [Giffin] $161(\mathrm{Mr})$

\section{Ear Canal}

congenital cholesteatoma of petrous pyramid [Horn] 621 (Se)

is there an auriculovagal reflex producing cardiac dysrhythmias? (letter) [Moorthy] 631 (Se)

management of, in head and neck surgery [Conley] $90(\mathrm{Fe})$

Ear Diseases

congenital cholesteatoma of petrous pyramid [Horn] 621 (Se)

Ear, External

auricular perichondritis secondary to acupuncture [Davis] 770 (No)

porous polyethylene in reconstructive head and neck surgery [Berghaus] $154(\mathrm{Mr})$

Ear, Internal see Labyrinth

Ear, Middle

benign adenoma of, resident's page [Little] 346 (My)

large cholesterol granuloma cysts in mastoid, clinical and histopathologic findings [Palva] 786 (De)

lidocaine in treatment of Meniere's disease (letter) [Simmons] $829(\mathrm{De})$

metabolic facial paralysis in infant [Sillman] 822 (De)

morning pressure in [Hergils] $86(\mathrm{Fe})$

sensorineural hearing loss in experimental purulent otitis media due to Streptococcus pneumonite [Morizono] 794 (De)

study of mucus glycoproteins in secretory otitis media [Brown] $688(\mathrm{Oc})$

temporal bone findings in otopalatodigital syndrome [Shi] $119(\mathrm{Fe})$

ventilating tubes (letters) [Healy, Levine] 416 (Je)

Ear Neoplasms

benign adenoma of middle ear, resident's page [Little] $346(\mathrm{My})$

management of ear canal in head and neck surgery [Conley] $90(\mathrm{Fe})$

Ear Ossicles

proximal symphalangia and stapes ankylosis [Cremers] 765 (No)

$\mathrm{X}$-linked progressive mixed deafness with perilymphatic gusher during stapes surgery [Cremers] 249 (Ap)

\section{Earache}

histoplasmosis of tonsil, resident's page [Davis] $558(\mathrm{Au})$

EDITORIAL FOOTNOTE

near-total pharyngeal reconstruction by 'rotarydoor' sternohyoid myocutaneous flap in dog [Bailey] 676 (Oc)

scale for evaluating results of rhinoplasty [Anderson] $520(\mathrm{Au})$

Education, Health see Health Education

Education, Medical

allergy and immunology training in otolaryngology residency programs [Osguthorpe] 779 (De)

Eicosatetraenoic Acids see Arachidonic Acids

Elastomers, Silicone see Silicone Elastomers

Electroacoustic Impedance Tests see Acoustic Impedance Tests 
Electrocardiography

is there an auriculovagal reflex producing cardiac dysrhythmias? (letter) [Moorthy] 631 (Se)

Electrocoagulation

approach to large nasoseptal perforations and attendant deformity [Belmont] 450 (Jy)

Electrocochleography see Audiometry, Evoked Response

Electromagnetic Fields see Electromagnetics

Electromagnetics

effects of magnetic resonance imaging fields on stapedectomy prostheses [Applebaum] 820 (De)

Electron Microscopy see Microscopy, Electron

Electrophysiology

3-dimensional reconstruction of cochlear nuclear complex in humans [Terr] 495 (Au)

nerve grafting, functional results after primary vs delayed repair [Ellis] 781 (De)

Electrosurgery

use of, in blepharoplasty [Colton] $441(\mathrm{Jy})$

Embolization, Therapeutic

posttraumatic pseudoaneurysm of extracranial middle meningeal artery [Jay] 264 (Ap)

Emergency Medical Services

hospital-based helicopter, threat to hearing? [Pasic] $507(\mathrm{Au})$

Enbucrilate

as cartilage adhesive in augmentation rhinoplasty [Sachs] 389 (Je)

Endolymphatic Duct see Labyrinth

Endolymphatic Sac see Labyrinth

Endoscopy

functional endoscopic sinus surgery, technique [Kennedy] 643 (Oc)

functional endoscopic sinus surgery, theory and diagnostic evaluation [Kennedy] 576 (Se)

role of, in evaluating patients with head and neck cancer, multi-institutional prospective study [Leipzig] 589 (Se)

Warthin's tumor arising in lymph node containing heterotopic salivary gland, resident's page [Cannon] $702(\mathrm{Oc})$

Enteral Feeding

tube esophagostomy, new technique in management of long-term swallowing disorders [Tucker] $187(\mathrm{Mr})$

Enteral Hyperalimentation see Enteral Feeding

Enterocolitis, Necrotizing see Enterocolitis, Pseudomembranous

Enterocolitis, Pseudomembranous

Clostridium difficile colitis following head and neck surgery, case reports [Griebie] 550 (Au)

Epidermis

medullary space involvement in laryngeal carcinoma, computed tomographic demonstration [Silverman] $541(\mathrm{Au})$

\section{Epinephrine}

dangers of propranolol withdrawal prior to local anesthesia with (letter) [Alexander] 280 (Ap)

otolaryngologists using local anesthetics containing (letter) [Roy] 280, (reply) [Brummett] (letter) [Ward] 281 (Ap)

Epistaxis

total ophthalmoplegia after internal maxillary artery ligation [Beall] 696 (Oc)

Epithelioma, Basal Cell see Carcinoma, Basal Cell

\section{Epithelium}

electron microscopy of olfactory epithelia in 2 patients with anosmia [Moran] $122(\mathrm{Fe})$

large cholesterol granuloma cysts in mastoid, clinical and histopathologic findings [Palva] 786 (De)

olfactory marker protein in human olfactory pathway [Nakashima] 294 (My)

role of allergy in pathogenesis of otitis media with effusion [Doyle] $502(\mathrm{Au})$

Equipment and Supplies

effects of magnetic resonance imaging fields on stapedectomy prostheses [Applebaum] 820
Equipment and Supplies - Continued (De)

external rhinoplasty approach to transsphenoidal hypophysectomy [Koltai] 456 (Jy)

reliability of sound-generating otoscope [Pearlman] 792 (De)

sensorineural hearing loss in experimental purulent otitis media due to Streptococcus pneumoniae [Morizono] 794 (De)

Esophagus

acceptability and intelligibility of tracheoesophageal speech [Tardy-Mitzell] 213 (Ap)

differences in speaking proficiencies in 3 laryngectomee groups [Williams] 216 (Ap)

dysphagia and Forestier's disease [Deutsch] 400 (Je)

improved esophageal insufflation test [Blom] 211 (Ap)

long-term results of Blom-Singer speech rehabilitation procedure [Wetmore] 106 (Fe)

near-total pharyngeal reconstruction by 'rotarydoor' sternohyoid myocutaneous flap in dog, preliminary report [Broniatowski] 673 (Oc)

pectoralis myocutaneous flap modifications (letter) [Stiernberg] $208(\mathrm{Mr})$

pharyngoesophageal reconstruction (letter) [Goepfert] (reply) [Robertson] 706 (Oc)

pharyngoesophageal reconstruction using free jejunal interposition grafts [Fisher] 747 (No)

pharyngoesophageal reconstruction, is skin-lined pharynx necessary? [Robertson] 375 (Je)

primary voice restoration at laryngectomy [Hamaker] $182(\mathrm{Mr})$

reconstruction options for pharyngeal and/or cervical esophageal defects [Schuller] 193 (Mr)

tracheoesophageal puncture prostheses (letter) [Blom] 208, (reply) [Weinberg] 209 (Mr)

tube esophagostomy, new technique in management of long-term swallowing disorders [Tucker] $187(\mathrm{Mr})$

Ethmoid Bone

medial orbital blow-out fracture with entrapment [Rauch] $53(\mathrm{Ja})$

Eustachian Tube

function in chinchilla [Doyle] 305 (My)

otitis media at Canyon Day, Ariz, 16-year followup in Apache Indians [Todd] 606 (Se)

role of allergy in pathogenesis of otitis media with effusion [Doyle] $502(\mathrm{Au})$

Evoked Potentials, Auditory

alterations induced by pulsed ultrasound [Moore] 309 (My)

brain-stem, during lidocaine infusion in humans [Ruth] 799 (De)

brain-stem, response waveform variation associated with recurrent otitis media [Lenhardt] 315 (My)

changing concepts of acoustic neuroma diagnosis [Barrs] 17 (Ja)

responses in multiple sclerosis, wave 1 abnormality [Verma] $22(\mathrm{Ja})$

Evoked Response Audiometry see Audiometry, Evoked Response

Exercise Therapy

perspectives on pharmacotherapy of vertigo [Zee] 609 (Se)

Exophthalmos

malar fractures associated with [Godoy] 174 (Mr)

Eyelids

blepharoplasty, indications and preoperative assessment [Holt] 394 (Je)

use of electrosurgery in blepharoplasty [Colton] 441 (Jy)

use of temporalis fascia in reconstruction of [Holt] $165(\mathrm{Mr})$

westernization of Asian eyelid [Matsunaga] 149 (Mr)
Face

aesthetic facial surgery in otolaryngology training program [Thomas] $141(\mathrm{Mr})$

atypical facial pain and orbital cancer [Ruff] 338 (My)

forehead lift (letter) [Chrisman] 827 (De)

forehead lift, review [Adamson] 325 (My)

porous polyethylene in reconstructive head and neck surgery [Berghaus] $154(\mathrm{Mr})$

profile analysis in facial plastic surgery [Larrabee] $682(\mathrm{Oc})$

reconstruction of half of [Conley] $142(\mathrm{Mr})$

temporalis muscle-galea flap in reanimation of [Mathog] 168 (Mr)

Facial Injuries

wrestler's ear (acute auricular hematoma) [Giffin] $161(\mathrm{Mr})$

Facial Neoplasms

management of ear canal in head and neck surgery [Conley] 90 (Fe)

Facial Nerve

meeting in Bordeaux (letter) [McGovern] 349 (My)

reconstruction of large nasal defects with subcutaneous pedicle nasolabial flap, underutilized technique [Levine] 628 (Se)

temporalis muscle-galea flap in facial reanimation [Mathog] $168(\mathrm{Mr})$

Facial Nerve Diseases

facial nerve palsy associated with Warthin's tumor [Lesser] $548(\mathrm{Au})$

Facial Paralysis

bilateral, Lyme disease, cause of [Glasscock] 47 (Ja)

facial nerve meeting in Bordeaux (letter) [McGovern] 349 (My)

facial nerve palsy associated with Warthin's tumor [Lesser] $548(\mathrm{Au})$

facial palsy (letter) [Asbrink] 349 (My)

facial palsy in Bannwarth's syndrome, tick-borne spirochetosis (letter) [Einhaeupl] $557(\mathrm{Au})$

metabolic, in infant [Sillman] 822 (De)

prognostic determination and submandibular function in Bell's palsy, dynamic testing with technetium Tc 99m [Yamashita] 244 (Ap)

Fascia

cervical, investing, glottic reconstruction with thyroid perichondrium and [Stegnjajic] 472 (Jy)

temporalis, use in eyelid reconstruction [Holt] $165(\mathrm{Mr})$

Fasciitis

nodular, resident's page [Fechner] $136(\mathrm{Fe})$

Fetus

auditory evoked potential alterations induced by pulsed ultrasound [Moore] $309(\mathrm{My})$

Fiber Optics

role of endoscopy in evaluating patients with head and neck cancer, multi-institutional prospective study [Leipzig] 589 (Se)

Fibrosarcoma

of larynx and pharynx in infant, fibromatosis and [McIntosh] 478 (Jy)

Filing

photographs and procedures, computer-based method of [Allan] $178(\mathrm{Mr})$

\section{Fingers}

temporal bone findings in otopalatodigital syndrome [Shi] $119(\mathrm{Fe})$

Fistula

Clostridium difficile colitis following head and neck surgery, case reports [Griebie] $550(\mathrm{Au})$

Flaps see Surgical Flaps

Flow Cytometry

DNA content of human squamous cell carcinoma cell lines, analysis by chromosome enumeration and [Roa] 565 (Se)

DNA, of thyroid neoplasms [Kraemer] $34(\mathrm{Ja})$

Fluoresceins

comparative assessment of blood flow to canine 
Floresceins - Continued

Bland flaps [Silverman] $677(\mathrm{Oc})$

Fliorometry

conparative assessment of blood flow to canine sland flaps [Silverman] $677(\mathrm{Oc})$

measurement of alternative blood flow in porcine )anniculus carnosus myocutaneous flap [Cumnings] 598 (Se)

Flıorouracil

and mitomycin with concomitant radiotherapy in iead and neck cancer [Kaplan] 220 (Ap)

mintenance chemotherapy for high-risk paients, preliminary report [Johnson] 727 (No)

Fdinic Acid see Citrovorum Factor

Fdlow-Up Studies

congenital cholesteatoma of petrous pyramid Horn] 621 (Se)

contralateral laryngoplasty, update on reconstruction of larynx following supraglottic laryngectomy with vertical extension [Friedman] 742 (No)

long-term, in cisplatin potentiation of radiotherapy [Leipzig] $114(\mathrm{Fe})$

mintenance chemotherapy for high-risk patients, preliminary report [Johnson] 727 (No)

16-year, in Apache Indians, otitis media at Canyon Day, Ariz [Todd] 606 (Se)

\section{Forehead}

flıp, oblique, for total reconstruction of nasal tip and columella [Baker] $425(\mathrm{Jy})$

lift (letter) [Chrisman] 827 (De)

lijt, review [Adamson] 325 (My)

Foreign Body Reaction

support of unstable nasal fractures with silicone rubber wedge splints [Colclasure] $443(\mathrm{Jy})$

Forestier's Disease see Spinal Osteophytosis

Forms and Records Control see Office Management

N-Formylmethionine Leucyl-Phenylalanine

defective monocyte chemotaxis in patients with epidermoid tumors of head and neck [Walter] $538(\mathrm{Au})$

Fractures

support of unstable nasal fractures with silicone rubber wedge splints [Colclasure] $443(\mathrm{Jy})$

Frontal Bone

autograft frontoplasty, simple technique for correction of post-osteoplastic flap defects [Myers] $626(\mathrm{Se})$

Fungi

deterioration of voice prostheses caused by fungal vegetations (letter) [Mahieu] 280 (Ap)

\section{G}

Gamma Camera Imaging see Radionuclide Imaging

Genetics, Medical

congenital cholesteatoma of petrous pyramid [Horn] 621 (Se)

otitis media at Canyon Day, Ariz, 16-year followup in Apache Indians [Todd] 606 (Se)

Gibbon see Hylobates

Gingiva

oral features of Wegener's granulomatosis [Handlers] 267 (Ap)

Gingivitis

Kaposi's sarcoma in patient with AIDS, resident's page [Lanser] $486(\mathrm{Jy})$

Glottis

contralateral laryngoplasty, update on reconstruction of larynx following supraglottic laryngectomy with vertical extension [Friedman] 742 (No)

cricoid collapse, new technique for management of glottic incompetence [Biller] 740 (No)

glottic reconstruction with thyroid perichondrium and investing cervical fascia [Stegnjajic] $472(\mathrm{Jy})$

neoglottic reconstruction following total laryngectomy [Tanabe] $39(\mathrm{Ja})$
Glycoproteins

mucus, in secretory otitis media, study of [Brown] 688 (Oc)

Goiter

deafness in developing countries, approaches to global program of prevention [Wilson] $2(\mathrm{Ja})$

Gonadotropins, Chorionic

modified neck dissection for metastatic testicular carcinoma [Zeph] 667 (Oc)

Gonadotropins, Chorionic, Human see Gonadotropins, Chorionic

Graft Survival

extension of musculocutaneous flap by surgical delay [Haughey] 234 (Ap)

mandibular reconstruction with A-O plate [Hilger] 469 (Jy)

pharyngoesophageal reconstruction using free jejunal interposition grafts [Fisher] 747 (No)

survival of myocutaneous flaps, experimental evaluation by intra-arterial injection of dye [Nieto] 43 (Ja)

\section{Granuloma}

large cholesterol, cysts in mastoid, clinical and histopathologic findings [Palva] 786 (De)

Gravity

auditory response to inverted posture (letter) [Plocher] $135(\mathrm{Fe})$

Gromnet Insertion see Middle Ear Ventilation

Gums see Gingiva

Head

and neck surgery, Clostridium difficile coiitis following, case reports [Griebie] $550(\mathrm{Au})$

Head and Neck Neoplasms

acute deafness, complication of high-dose cisplatin [Guthrie] 344 (My)

angiofollicular lymphoid hyperplasia, hyaline vascular variant (giant lymph node hyperplasia [GLNH], Castleman's disease), resident's page [Schroeder] 772 (No)

cervical neurilemoma (schwannoma), resident's page [Barat] 276 (Ap)

cisplatin potentiation of radiotherapy, long-term follow-up [Leipzig] 114 (Fe)

combined functional oral rehabilitation after radical cancer surgery [Wurster] $530(\mathrm{Au})$

computed tomography of cervical lymph nodes, staging and management of head and neck cancer [Stevens] 735 (No)

defective monocyte chemotaxis in patients with epidermoid tumors of head and neck [Walter] $538(\mathrm{Au})$

definite vs adjuvant radiotherapy, comparative effects on lymphocyte subpopulations in patients with head and neck squamous carcinoma [Wolf] 716 (No)

fibromatosis and fibrosarcoma of larynx and pharynx in infant [McIntosh] $478(\mathrm{Jy})$

glottic reconstruction with thyroid perichondrium and investing cervical fascia [Stegnjajic] $472(\mathrm{Jy})$

immunomodulation of nodal lymphocytes in head and neck cancer [Schuller] $465(\mathrm{Jy})$

intramuscular myxoma of neck [Nishijima] 699 (Oc)

iridium-192 implants in treatment of tonsillar region malignancies [Puthawala] 812 (De) irradiation after neck dissection (letters) [Blitzer, Vikram] 827 (reply) [DeSanto] 828 (De)

magnetic resonance imaging vs computed tomography, comparison in imaging oral cavity and pharyngeal carcinomas [Schaefer] 730 (No)

maintenance chemotherapy for high-risk patients, preliminary report [Johnson] 727 (No)

management of ear canal in surgery for [Conley] $90(\mathrm{Fe})$

mitomycin and fluorouracil with concomitant radiotherapy in [Kaplan] 220 (Ap)

modified neck dissection for metastatic testicular carcinoma [Zeph] $667(\mathrm{Oc})$
Head and Neck Neoplasms - Continued

neck dissection and combined therapy, study of effectiveness [DeSanto] 366 (Je)

photodynamic therapy in [Schuller] $351(\mathrm{Je})$

photodynamic therapy in otolaryngology-head and neck surgery [Keller] 758 (No)

reconstruction options for pharyngeal and/or cervical esophageal defects [Schuller] 193 (Mr)

role of endoscopy in evaluating patients with, multi-institutional prospective study [Leipzig] $589(\mathrm{Se})$

squamous cell carcinoma of head and neck in patients under 40 years of age [Mendez] 762 (No)

we must stop selling cancer to our children [Bailey] 637 (Oc)

Head Injuries

posttraumatic pseudoaneurysm of extracranial middle meningeal artery [Jay] 264 (Ap)

Headache

hidrocystoma of apocrine gland derivation, resident's page [Hagan] $772(\mathrm{No})$

lateral sinus thrombosis, medical or surgical treatment? [Goldenberg] 56 (Ja)

\section{Health Education}

patterns of use and incidence of smokeless tobacco consumption in school-age children [Schaefer] $639(\mathrm{Oc})$

\section{Hearing}

acuity of children with otitis media with effusion [Fria] $10(\mathrm{Ja})$

auditory capabilities of single-channel cochlear implant patients, etiologic considerations [Edgerton] 255 (Ap)

hospital-based helicopter, threat to? [Pasic] 507 (Au)

Meniere's disease (syndrome?) [Kohut] 494 (Au)

Hearing Loss, Bilateral see Hearing Loss, Partial

Hearing Loss, Central see Hearing Loss, Sensorineural

Hearing Loss, Conductive see Hearing Loss, Partial

Hearing Loss, Functional see Hearing Loss, Partial

Hearing Loss, High-Frequency see Hearing Loss, Partial

Hearing Loss, Noise-Induced

deafness in developing countries, approaches to global program of prevention [Wilson] $2(\mathrm{Ja})$

Hearing Loss, Partial

auditory response to inverted posture (letter) [Plocher] 135 (Fe)

prevention of hearing impairment from infection and ototoxic drugs [Catlin] 377 (Je)

proximal symphalangia and stapes ankylosis [Cremers] 765 (No)

temporal bone findings in otopalatodigital syndrome [Shi] $119(\mathrm{Fe})$

Hearing Loss, Sensorineural

electrocochleography and symptoms of inner ear dysfunction [Ferraro] $71(\mathrm{Fe})$

in experimental purulent otitis media due to Streptococcus pneumoniae [Morizono] 794 (De)

Hearing Tests

amino-oxyacetic acid as palliative in tinnitus [Reed] 803 (De)

reliability of sound-generating otoscope [Pearlman] $792(\mathrm{De})$

Heart Arrest

cardiopulmonary arrest due to misuse of viscous lidocaine [Puczynski] 768 (No)

Heart Rate

is there an auriculovagal reflex producing cardiac dysrhythmias? (letter) [Moorthy] 631 (Se)

Hematoma

acute auricular, wrestler's ear [Giffin] 161 (Mr)

Hematoporphyrins

advances in laser skin surgery for vascular 
Hematoporphyrins-Continued lesions [Keller] 437 (Jy)

photodynamic therapy in head and neck cancer [Schuller] 351 (Je)

photodynamic therapy in otolaryngology-head and neck surgery [Keller] 758 (No)

Hemosiderin

large cholesterol granuloma cysts in mastoid, clinical and histopathologic findings [Palva] $786(\mathrm{De})$

\section{Hereditary Diseases}

$\mathrm{X}$-linked progressive mixed deafness with perilymphatic gusher during stapes surgery [Cremers] 249 (Ap)

Histoplasmosis

of tonsil, resident's page [Davis] $558(\mathrm{Au})$

Hoarseness

laryngeal cyst of thyroid cartilage [Burgess] 826 (De)

medullary space involvement in laryngeal carcinoma, computed tomographic demonstration [Silverman] $541(\mathrm{Au})$

Homosexuality

acquired immune deficiency syndrome-related lymphadenopathies presenting in salivary gland lymph nodes [Ryan] $554(\mathrm{Au})$

Kaposi's sarcoma in patient with AIDS, resident's page [Lanser] $486(\mathrm{Jy})$

House Staff see Internship and Residency

Hyaline Substance

angiofollicular lymphoid hyperplasia, hyaline vascular variant (giant lymph node hyperplasia [GLNH], Castleman's disease), resident's page [Schroeder] $772(\mathrm{No})$

Hybridization

papillomavirus-DNA, interferon therapy for bronchial papillomatosis controlled by [Ikenberg] $96(\mathrm{Fe})$

verrucous carcinoma of larynx, possible human papillomavirus etiology [Abramson] 709 (No)

\section{Hylobates}

proximal symphalangia and stapes ankylosis [Cremers] 765 (No)

Hyoid Bone

intramuscular myxoma of neck [Nishijima] 699 (Oc)

near-total pharyngeal reconstruction by 'rotarydoor' sternohyoid myocutaneous flap in dog, preliminary report [Broniatowski] $673(\mathrm{Oc})$

Hyperalimentation, Enteral see Enteral Feeding

Hyperplasia

oral features of Wegener's granulomatosis [Handlers] 267 (Ap)

Hypersensitivity

prostaglandins and other metabolites of arachidonic acid [Poole] $317(\mathrm{My})$

Hypersomnia with Periodic Respiration see Sleep Apnea Syndromes

Hypertension

dangers of propranolol withdrawal prior to local anesthesia with epinephrine (letter) [Alexander] $280(\mathrm{Ap})$

otolaryngologists using local anesthetics containing epinephrine (letter) [Roy] 280, (reply) [Brummett] (letter) [Ward] 281 (Ap)

Hypohidrosis see Sweat Glands

Hypoparathyroidism

pharyngoesophageal reconstruction using free jejunal interposition grafts [Fisher] 747 (No) Hypopharynx

reconstruction options for pharyngeal and/or cervical esophageal defects [Schuller] 193 $(\mathrm{Mr})$

role of endoscopy in evaluating patients with head and neck cancer, multi-institutional prospective study [Leipzig] 589 (Se)

Hypophysectomy

transsphenoidal, external rhinoplasty approach to [Koltai] $456(\mathrm{Jy})$

Hypoventilation, Central Alveolar see Sleep Apnea Syndromes

\section{Hypoxemia see Anoxemia}

$\lg G$

definite vs adjuvant radiotherapy, comparative effects on lymphocyte subpopulations in patients with head and neck squamous carcinoma [Wolf] 716 (No)

$\lg M$

definite vs adjuvant radiotherapy, comparative effects on lymphocyte subpopulations in patients with head and neck squamous carcinoma [Wolf] 716 (No)

Immune Tolerance see Immunosuppression

Immunoblastic Lymphadenopathy

acquired immune deficiency syndrome-related lymphadenopathies presenting in salivary gland lymph nodes [Ryan] $554(\mathrm{Au})$

Immunoglobulins

circulating immunocomplexes and laryngeal carcinoma [Denaro] 595 (Se)

Immunologic Deficiency Syndromes

infections of nose and paranasal sinuses in adult patients with [Karlsson] $290(\mathrm{My})$

Immunosuppression

airway obstruction in immunosuppressed child [Myer] 409 (Je)

definite vs adjuvant radiotherapy, comparative effects on lymphocyte subpopulations in patients with head and neck squamous carcinoma [Wolf] 716 (No)

Impedance Tests, Acoustic see Acoustic Impedance Tests

Implants, Artificial see also Biocompatible Materials

effects of magnetic resonance imaging fields on stapedectomy prostheses [Applebaum] 820 (De)

incus see Ear Ossicles

Indians, North American

otitis media at Canyon Day, Ariz, 16-year followup in Apache Indians [Todd] 606 (Se)

Infant

cardiopulmonary arrest due to misuse of viscous lidocaine [Puczynski] 768 (No)

fibromatosis and fibrosarcoma of larynx and pharynx in [McIntosh] 478 (Jy)

metabolic facial paralysis in [Sillman] 822 (De)

Infection

of nose and paranasal sinuses in adult patients with immunodeficiency [Karlsson] 290 ( $\mathrm{My}$ )

prevention of hearing impairment from ototoxic drugs and [Catlin] 377 (Je)

Inflammation

auricular perichondritis secondary to acupuncture [Davis] $770(\mathrm{No})$

facial nerve palsy associated with Warthin's tumor [Lesser] $548(\mathrm{Au})$

prostaglandins and other metabolites of arachidonic acid [Poole] $317(\mathrm{My})$

Injections

intratympanic, with lidocaine, treatment of Meniere's disease by [Fradis] 491 ( $\mathrm{Au}$ )

lidocaine in treatment of Meniere's disease (letter) [Simmons] 829 (De)

Injections, Intra-Arterial

survival of myocutaneous flaps, experimental evaluation by intra-arterial injection of dye [Nieto] 43 ( Ja)

injections, Intravenous

role of allergy in pathogenesis of otitis media with effusion [Doyle] $502(\mathrm{Au})$

Injuries see Wounds and Injuries

Injuries, Nonpenetrating see Wounds, Nonpenetrating

Intensive Care Units

auditory brain-stem response in determination of brain death [Hall] 613 (Se)

Interferon, Alpha see Interferon Type

Interferon, Beta see Interferon Type 1
Interferon, Fibroblast see Interferon Type 1 Interferon, Leukocyte see Interferon Type Interferon, Lymphoblast see Interferon Type 1 Interferon Type 1

therapy for bronchial papillomatosis controlled by papillomavirus-DNA hybridization [Ikenberg] $96(\mathrm{Fe})$

Internship and Residency

aesthetic facial surgery in otolaryngology training program [Thomas] $141(\mathrm{Mr})$

Intracranial Arteriovenous Malformations see

Cerebral Arteriovenous Malformations

Intraoperative Complications see Surgery, Operative

Intraoperative Period see Surgery, Operative

Intubation

tube esophagostomy, new technique in management of long-term swallowing disorders [Tucker] $187(\mathrm{Mr})$

ventilating tubes (letters) [Healy, Levine] 416 (Je)

Iridium

192 , implants in treatment of tonsillar region malignancies [Puthawala] 812 (De)

Island Flaps see Surgical Flaps

Jejunum

pharyngoesophageal reconstruction using free jejunal interposition grafts [Fisher] 747 (No)

Joint Tuberculosis see Tuberculosis, Osteoarticular

Jugal Bone see Zygoma

Kaposi's Sarcoma see Sarcoma, Kaposi's

Keratin

cytoskeletal proteins in oncocytic tumors of parotid gland [Gustafsson] 99 (Fe)

large cholesterol granuloma cysts in mastoid, clinical and histopathologic findings [Palva] 786 (De)

Ketoconazole

Kaposi's sarcoma in patient with AIDS, resident's page [Lanser] $486(\mathrm{Jy})$

L

Labyrinth

electrocochleography and symptoms of inner ear dysfunction [Ferraro] $71(\mathrm{Fe})$

Meniere's disease (syndrome?) [Kohut] 494 ( $\mathrm{Au}$ )

temporal bone findings in otopalatodigital syndrome [Shi] $119(\mathrm{Fe})$

Labyrinth Supporting Cells see Organ of Corti

Labyrinthine Fluids

endolymphatic hydrops in guinea pigs after cauterizing sac with silver nitrate [Yazawa] 301 (My)

$\mathrm{X}$-linked progressive mixed deafness with perilymphatic gusher during stapes surgery [Cremers] 249 (Ap)

Labyrinthitis

sensorineural hearing loss in experimental purulent otitis media due to Streptococcus pneumoniae [Morizono] 794 (De)

Lacrimal Apparatus

blepharoplasty, indications and preoperative assessment [Holt] 394 (Je)

Langerhans Cells

intranasal dermal analogue tumor (membranous basal cell adenoma), ultrastructure and immunohistochemistry [Zarbo] $333(\mathrm{My})$

Laryngeal Cartilages

contralateral laryngoplasty, update on reconstruction of larynx following supraglottic laryngectomy with vertical extension [Friedman] 742 (No)

cricoid collapse, new technique for management of glottic incompetence [Biller] 740 (No)

difficulty in high-pitched phonation by laryngeal 
Laryngeal Cartilages - Continued

trauma [Hirano] $59(\mathrm{Ja})$

feasibility of subtotal laryngectomy based on whole-organ examination [Robbins] 356 (Je)

glottic reconstruction with thyroid perichondrium and investing cervical fascia [Stegnjajic] $472(\mathrm{Jy})$

laryngeal cyst of thyroid cartilage [Burgess] 826 (De)

laryngeal perichondritis and abscess [Souliere] $481(\mathrm{Jy})$

laser arytenoidectomy [Lim] 262 (Ap)

medullary space involvement in laryngeal carcinoma, computed tomographic demonstration [Silverman] $541(\mathrm{Au})$

pathogenesis of protruded false vocal fold [Honjo] 398 (Je)

3-dimensional distribution of neuromuscular junctions in human cricothyroid [De Vito] 110 $(\mathrm{Fe})$

\section{Laryngeal Neoplasms}

circulating immunocomplexes and laryngeal carcinoma [Denaro] 595 (Se)

conservation laryngeal surgery, critical analysis [Maceri] 361 (Je)

feasibility of subtotal laryngectomy based on whole-organ examination [Robbins] 356 (Je)

malignant lymphoma, resident's page [Frierson] $136(\mathrm{Fe})$

medullary space involvement in laryngeal carcinoma, computed tomographic demonstration [Silverman] 541 (Au)

oncocytoma, resident's page [Schwenzfeier] 412 (Je)

squamous cell carcinoma of head and neck in patients under 40 years of age [Mendez] 762 (No)

verrucous carcinoma of larynx, possible human papillomavirus etiology [A bramson] 709 (No)

Laryngeal Paralysis see Vocal Cord Paralysis

Laryngeal Perichondritis

and abscess [Souliere] $481(\mathrm{Jy})$

Laryngectomy see also Speech, Alaryngeal

conservation laryngeal surgery, critical analysis [Maceri] 361 (Je)

cricoid collapse, new technique for management of glottic incompetence [Biller] 740 (No)

differences in speaking proficiencies in 3 laryngectomee groups [Williams] 216 (Ap)

fibromatosis and fibrosarcoma of larynx and pharynx in infant [McIntosh] 478 (Jy)

glottic reconstruction with thyroid perichondrium and investing cervical fascia [Stegnjajic] $472(\mathrm{Jy})$

improved esophageal insufflation test [Blom] 211 (Ap)

near-total pharyngeal reconstruction by 'rotarydoor' sternohyoid myocutaneous flap in dog, preliminary report [Broniatowski] $673(\mathrm{Oc})$

primary voice restoration at [Hamaker] 182 (Mr)

subtotal, feasibility of, based on whole-organ examination [Robbins] 356 (Je)

supraglottic, with vertical extension, contralateral laryngoplasty, update on reconstruction of larynx following [Friedman] 742 (No)

total, neoglottic reconstruction following [Tanabe] 39 (Ja)

tracheal stoma reconstruction [Panje] 190 (Mr)

Laryngoscopy

complications of Venturi jet ventilation during microlaryngeal surgery [O'Sullivan] $127(\mathrm{Fe})$

pathogenesis of protruded false vocal fold [Honjo] 398 (Je)

Larynx

complications of Venturi jet ventilation during microlaryngeal surgery [O'Sullivan] $127(\mathrm{Fe})$

contralateral laryngoplasty, update on reconstruction of larynx following supraglottic laryngectomy with vertical extension [Friedman] $742(\mathrm{No})$
Larynx-Continued

difficulty in high-pitched phonation by laryngeal trauma [Hirano] $59(\mathrm{Ja})$

fibromatosis and fibrosarcoma of pharynx and, in infant [McIntosh] 478 (Jy)

twisted, clinical syndrome (letter) [Lewy] (ed. reply) [Bailey] $557(\mathrm{Au})$

Lasers

advances in laser skin surgery for vascular lesions [Keller] $437(\mathrm{Jy})$

carbon dioxide laser stapedotomy, thermal effects in vestibule [Coker] 601 (Se)

comparative assessment of blood flow to canine island flaps [Silverman] 677 (Oc)

complications of Venturi jet ventilation during microlaryngeal surgery [O'Sullivan] $127(\mathrm{Fe})$

laser arytenoidectomy [Lim] 262 (Ap)

laser turbinectomy as adjunct to rhinoseptoplasty [Selkin] 446 (Jy)

measurement of alternative blood flow in porcine panniculus carnosus myocutaneous flap [Cummings] 598 (Se)

photodynamic therapy in head and neck cancer [Schuller] 351 (Je)

photodynamic therapy in otolaryngology-head and neck surgery [Keller] 758 (No)

\section{Legislation Medical}

smokeless tobacco, open letter to Surgeon General [Bailey] 707 (No)

Leucovorin see Citrovorum Factor

Leukocytes, Polymorphonuclear see Neutrophils

\section{Leukotrienes B}

prostaglandins and other metabolites of arachidonic acid [Poole] 317 (My)

\section{Lichen Planus}

oral, and squamous carcinoma, case report and literature update [Kaplan] $543(\mathrm{Au})$

\section{Lidocaine}

amino-oxyacetic acid as palliative in tinnitus [Reed] 803 (De)

in treatment of Meniere's disease (letter) [Simmons] 829 (De)

infusion, brain-stem auditory-evoked potentials during, in humans [Ruth] 799 (De)

plasma concentrations following administration of intraoral lidocaine solution [Greenblatt] 298 (My)

treatment of Meniere's disease by intratympanic injection with [Fradis] $491(\mathrm{Au})$

iscous, cardiopulmonary arrest due to misuse of [Puczynski] 768 (No)

\section{Ligation}

internal maxillary artery, total ophthalmoplegia after [Beall] $696(\mathrm{Oc})$

Lip

oblique forehead flap for total reconstruction of nasal tip and columella [Baker] $425(\mathrm{Jy})$

reconstruction of large nasal defects with subcutaneous pedicle nasolabial flap, underutilized technique [Levine] 628 (Se)

trapdoor effect in nasolabial flaps, causes and corrections [Koranda] $421(\mathrm{Jy})$

Liver

transplantation, airway obstruction in immunosuppressed child [Myer] 409 (Je)

Lung Neoplasms

photodynamic therapy in otolaryngology-head and neck surgery [Keller] 758 (No)

role of endoscopy in evaluating patients with head and neck cancer, multi-institutional prospective study [Leipzig] 589 (Se)

\section{Lyme Disease}

cause of bilateral facial paralysis [Glasscock] 47 (Ja)

\section{Lymph Nodes}

angiofollicular lymphoid hyperplasia, hyaline vascular variant (giant lymph node hyperplasia [GLNH], Castleman's disease), resident's page [Schroeder] 772 (No)

cervical lymph node metastases, incidence and
Lymph Nodes - Continued

implications of extracapsular carcinoma [Johnson] $534 \mathrm{(Au})$

cervical, computed tomography of, staging and management of head and neck cancer [Stevens] 735 (No)

magnetic resonance imaging vs computed tomography, comparison in imaging oral cavity and pharyngeal carcinomas [Schaefer] 730 (No)

salivary gland, acquired immune deficiency syndrome-related lymphadenopathies presenting in [Ryan] $554(\mathrm{Au})$

\section{Lymphadenitis}

cervical mycobacterial, medical vs surgical management [Castro] $816(\mathrm{De})$

\section{Lymphatic Diseases}

computed tomography of cervical lymph nodes, staging and management of head and neck cancer [Stevens] 735 (No)

modified neck dissection for metastatic testicular carcinoma [Zeph] $667(\mathrm{Oc})$

\section{Lymphocytes}

nodal, immunomodulation of, in head and neck cancer [Schuller] 465 (Jy)

\section{T Lymphocytes}

definite vs adjuvant radiotherapy, comparative effects on lymphocyte subpopulations in patients with head and neck squamous carcinoma [Wolf] 716 (No)

Lymphocytic Choriomeningitis

facial palsy in Bannwarth's syndrome, tick-borne spirochetosis (letter) [Einhaeupl] $557(\mathrm{Au})$

\section{Lymphokines}

immunomodulation of nodal lymphocytes in head and neck cancer [Schuller] $465(\mathrm{Jy})$

\section{Lymphoma}

acquired immune deficiency syndrome-related lymphadenopathies presenting in salivary gland lymph nodes [Ryan] $554(\mathrm{Au})$

malignant, resident's page [Frierson] 136 (Fe)

primary $\mathrm{CNS}$, in cerebellopontine angle [Ieroko$\operatorname{mos}] 50(\mathrm{Ja})$

unilocular cystic sebaceous lymphadenoma of parotid gland [Merwin] 273 (Ap)

Lymphoma, Giant Follicular

angiofollicular lymphoid hyperplasia, hyaline vascular variant (giant lymph node hyperplasia [GLNH], Castleman's disease), resident's page [Schroeder] 772 (No)

\section{Macaca mulatta}

role of allergy in pathogenesis of otitis media with effusion [Doyle] $502(\mathrm{Au})$

\section{Macrophage Activation}

immunomodulation of nodal lymphocytes in head and neck cancer [Schuller] 465 (Jy)

\section{Macrophages}

large cholesterol granuloma cysts in mastoid clinical and histopathologic findings [Palva] 786 (De)

Magnetic Resonance see Nuclear Magnetic Resonance

Malar Bone see Zygoma

Malleus see Ear Ossicles

\section{Mandible}

angiofollicular lymphoid hyperplasia, hyaline vascular variant (giant lymph node hyperplasia [GLNH], Castleman's disease), resident's page [Schroeder] 772 (No)

complete mandibular agenesis [Brecht] $132(\mathrm{Fe})$

mandibular reconstruction with $\mathrm{A}-\mathrm{O}$ plate [Hilger] $469(\mathrm{Jy})$

reconstruction with trapezius osteomusculocutaneous flap [Panje] 223 (Ap)

trapezius osteomyocutaneous flap for reconstruction of [Gregor] $198(\mathrm{Mr})$

\section{Marsupialia}

congenital cholesteatoma of petrous pyramid [Horn] 621 (Se) 


\section{Mastication}

histoplasmosis of tonsil, resident's page [Davis] $558(\mathrm{Au})$

\section{Masticatory Muscles}

temporalis muscle-galea flap in facial reanimation [Mathog] $168(\mathrm{Mr})$

\section{Mastoid}

congenital cholesteatoma of petrous pyramid [Horn] 621 (Se)

large cholesterol granuloma cysts in, clinical and histopathologic findings [Palva] 786 (De)

Maxillary Artery

internal, ligation, total ophthalmoplegia after [Beall] 696 (Oc)

Maxillary Diseases

odontogenic keratocyst, resident's page [Dierks] 346 (My)

Maxillary Fractures

calvarial grafts for midface rehabilitation [Cinberg] $434(\mathrm{Jy})$

Maxillary Sinus

functional endoscopic sinus surgery, theory and diagnostic evaluation [Kennedy] 576 (Se); technique [Kennedy] 643 (Oc)

Maxillary Sinus Neoplasms see Paranasal Sinus Neoplasms

\section{Measles}

prevention of hearing impairment from infection and ototoxic drugs [Catlin] 377 (Je)

Measles, German see Rubella

Medical Devices see Equipment and Supplies

Megacolon

Clostridium difficile colitis following head and neck surgery, case reports [Griebie] 550 (Au)

Membranes see Synovial Membrane

Meniere's Disease

electrocochleography and symptoms of inner ear dysfunction [Ferraro] 71 (Fe)

endolymphatic hydrops in guinea pigs after cauterizing sac with silver nitrate [Yazawa] 301 (My)

lidocaine in treatment of (letter) [Simmons] 829 (De)

Meniere's Disease (syndrome?) [Kohut] 494 (Au)

treatment of, by intratympanic injection with lidocaine [Fradis] 491 ( $\mathrm{Au})$

Meningeal Arteries

posttraumatic pseudoaneurysm of extracranial middle meningeal artery [Jay] 264 (Ap)

Meningitis

deafness in developing countries, approaches to global program of prevention [Wilson] 2 (Ja)

prevention of hearing impairment from infection and ototoxic drugs [Catlin] $377(\mathrm{Je})$

\section{Metabolism}

Clostridium difficile colitis following head and neck surgery, case reports [Griebie] 550 (Au)

\section{Metanephrine see Epinephrine}

Metastasis see Neoplasm Metastasis

Methotrexate

maintenance chemotherapy for high-risk patients, preliminary report [Johnson] 727 (No)

Microcomputers see Computers

Microfluorometry, Flow see Flow Cytometry

Microscopy

sensorineural hearing loss in experimental purulent otitis media due to Streptococcus pneumo niae [Morizono] 794 (De)

Microscopy, Electron

of olfactory epithelia in 2 patients with anosmia [Moran] $122(\mathrm{Fe})$

Microscopy, Electron, Scanning

3-dimensional reconstruction of cochlear nuclear complex in humans [Terr] $495 \mathrm{Au})$

Microsurgery

complications of Venturi jet ventilation during microlaryngeal surgery [O'Sullivan] $127(\mathrm{Fe})$

Middle Ear Ventilation

role of allergy in pathogenesis of otitis media with effusion [Doyle] $502(\mathrm{Au})$

\section{Mitomycin}

and fluorouracil with concomitant radiotherapy

in head and neck cancer [Kaplan] 220 (Ap)

Mitosis

inverted papilloma, considerations in treatment

[Woodson] 806 (De)

Mitotic Index see Mitosis

Monitoring, Physiologic

circulating immunocomplexes and laryngeal carcinoma [Denaro] 595 (Se)

Monkey, Rhesus see Macaca mulatta

Monocytes

chemotaxis, defective, in patients with epidermoid tumors of head and neck [Walter] 538 (Au)

Mortality

give priceless gift this year [Bailey] $777(\mathrm{De})$

malignant salivary gland tumors of base of tongue [Kessler] $664(\mathrm{Oc})$

Motion Sickness

perspectives on pharmacotherapy of vertigo [Zee 609 (Se)

Motor Endplate see Neuromuscular Junction

Mouth

oral cavity reconstruction using pectoralis major muscle and amnion [Lawson] 230 (Ap)

oral features of Wegener's granulomatosis [Handlers] 267 (Ap)

Mouth Floor

extended palatal island mucoperiosteal flap [Gullane] 330 (My)

Mouth Neoplasms

combined functional oral rehabilitation after radical cancer surgery [Wurster] $530(\mathrm{Au})$

smokeless tobacco, open letter to Surgeon General [Bailey] 707 (No)

Mucocele

of submandibular gland [Surkin] 623 (Se)

Mucormycosis

rhinocerebral, resident's page [Walker] 276 (Ap)

Mucous Membrane

near-total pharyngeal reconstruction by 'rotarydoor' sternohyoid myocutaneous flap in dog preliminary report [Broniatowski] $673(\mathrm{Oc})$

new twist in nasal tip surgery, alternative to Goldman tip for wide or bulbous lobule [McCollough] 524 (Au)

oral lichen planus and squamous carcinoma, case report and literature update [Kaplan] 543 (Au)

Mucus

functional endoscopic sinus surgery, technique [Kennedy] 643 (Oc)

glycoproteins in secretory otitis media, study of [Brown] $688(\mathrm{Oc})$

role of allergy in pathogenesis of otitis media with effusion [Doyle] $502(\mathrm{Au})$

Multiple Sclerosis

auditory evoked responses in, wave 1 abnormality [Verma] $22(\mathrm{Ja})$

Muscles

expansion of myocutaneous flaps [Forte] 371 (Je)

extension of musculocutaneous flap by surgical delay [Haughey] 234 (Ap)

mandible reconstruction with trapezius osteomusculocutaneous flap [Panje] 223 (Ap)

survival of myocutaneous flaps, experimental evaluation by intra-arterial injection of dye [Nieto] $43(\mathrm{Ja})$

3-dimensional distribution of neuromuscular junctions in human cricothyroid [De Vito] 110 (Fe)

trapezius osteomyocutaneous flap for mandibular reconstruction [Gregor] $198(\mathrm{Mr})$

Mycobacterium Infections

cervical mycobacterial lymphadenitis, medical vs surgical management [Castro] 816 (De)

Mycobacterium Infections, Atypical see Mycobacterium Infections
Mycobacterium tuberculosis

cervical mycobacterial lymphadenitis, medical vs surgical management [Castro] 815 (De)

Myelin Sheath

3-dimensional reconstruction of cochlear nuclear complex in humans [Terr] $495(\mathrm{Au})$

Myoneural Junction see Neuromuscular Junction

Myringoplasty

surgery in elderly patients with chronic otitis media [Vartiainen] $509(\mathrm{Au})$

\section{Myxoma}

intramuscular, of neck [Nishijima] 699 (Oc)

\section{N}

Nasal Bone

support of unstable nasal fractures with silicone rubber wedge splints [Colclasure] $443(\mathrm{Jy})$

Nasal Cavity

total inferior turbinectomy for nasal airway obstruction [Ophir] $93(\mathrm{Fe})$

Nasal Polyps

antral choanal, resident's page [Clegg] 634 (Se)

hairy, resident's page [Clegg] $634(\mathrm{Se})$

Nasal Septum

approach to large nasoseptal perforations and attendant deformity [Belmont] 450 (Jy)

external rhinoplasty approach to transsphenoidal hypophysectomy [Koltai] 456 (Jy)

intranasal composite grafts for dorsal support [Conley] 241 (Ap)

oblique forehead flap for total reconstruction of nasal tip and columella [Baker] 425 (Jy)

surgical anatomy of septorhinoplasty [Lessard] 25 (Ja)

Nasopharyngeal Neoplasms

chemotherapy for aggressive juvenile angiofibroma [Goepfert] 285 (My)

chondroid variant of chordoma, resident's page [Fechner] $66(\mathrm{Ja})$

use of malar bone graft to augment skull-base access [Mann] $30(\mathrm{Ja})$

Nasopharyngitis see Pharyngitis

Nasopharynx

hairy polyp, resident's page [Clegg] $634(\mathrm{Se})$

nasopharyngeal stenosis [Cotton] $146(\mathrm{Mr})$

National Center for Health Care Technology see United States Public Health Service

National Center for Health Statistics (US) see United States Public Health Service Neck

abscess, Salmonella dublin [Bello] 476 (Jy)

and head surgery, Clostridium difficile colitis following, case reports [Griebie] 550 (Au)

cervical lymph node metastases, incidence and implications of extracapsular carcinoma [Johnson] $534(\mathrm{Au})$

cervical mycobacterial lymphadenitis, medical vs surgical management [Castro] 815 (De)

dynamic computed tomography, assessment of vascular malformations and angiofibroma [Hill] $62(\mathrm{Ja})$

glottic reconstruction with thyroid perichondrium and investing cervical fascia [Stegnjajic] $472(\mathrm{Jy})$

reconstruction options for pharyngeal and/or cervical esophageal defects [Schuller] 193 (Mr)

Neck Neoplasms see Head and Neck Neoplasms

Necrosis

facial nerve palsy associated with Warthin's tumor [Lesser] $548(\mathrm{Au})$

Neoplasm Metastasis

cervical lymph node metastases, incidence and implications of extracapsular carcinoma [Johnson] $534(\mathrm{Au})$

computed tomography of cervical lymph nodes, staging and management of head and neck cancer [Stevens] 735 (No) 
Neoplasm Metastasis - Continued

DNA content of human squamous cell carcinoma cell lines, analysis by flow cytometry and chromosome enumeration [Roa] 565 (Se)

inverted papilloma, considerations in treatment [Woodson] 806 (De)

iridium-192 implants in treatment of tonsillar region malignancies [Puthawala] $812(\mathrm{De})$

irradiation after neck dissection (letters) [Blitzer, Vikram] 827 (reply) [DeSanto] 828 (De)

magnetic resonance imaging vs computed tomography, comparison in imaging oral cavity and pharyngeal carcinomas [Schaefer] 730 (No)

maintenance chemotherapy for high-risk patients, preliminary report [Johnson] 727 (No)

malignant salivary gland tumors of base of tongue [Kessler] $664(\mathrm{Oc})$

modified neck dissection for metastatic testicular carcinoma [Zeph] 667 (Oc)

neck dissection and combined therapy, study of effectiveness [DeSanto] 366 (Je)

photodynamic therapy in head and neck cancer [Schuller] 351 (Je)

role of endoscopy in evaluating patients with head and neck cancer, multi-institutional prospective study [Leipzig] 589 (Se)

squamous cell carcinoma of head and neck in patients under 40 years of age [Mendez] 762 (No)

tumors of parapharyngeal space [Shoss] 753 (No)

Neoplasm Staging

computed tomography of cervical lymph nodes, staging and management of head and neck cancer [Stevens] 735 (No)

Neoplasm Stem Cell Assay see Tumor Stem Cell Assay

Neoplasms

prostaglandins and other metabolites of arachidonic acid [Poole] 317 (My)

Neovascularization

osteogenesis in vascularized periosteum, interactions with underlying bone [Canalis] 511 (Au)

Nieurilemmoma

cervical (schwannoma), resident's page [Barat] $276(\mathrm{Ap})$

Neuroma, Acoustic

diagnosis, changing concepts of [Barrs] $17(\mathrm{Ja})$

Neuromuscular Junction

3:-dimensional distribution of, in human cricothyroid [De Vito] 110 (Fe)

Neurosurgery

lateral sinus thrombosis, medical or surgical treatment? [Goldenberg] $56(\mathrm{Ja})$

Neutrophils

diefective monocyte chemotaxis in patients with epidermoid tumors of head and neck [Walter] $538(\mathrm{Au})$

NEWS AND COMMENT

$710(\mathrm{Ja}), 140(\mathrm{Fe}), 210(\mathrm{Mr}), 282(\mathrm{Ap}), 350(\mathrm{My}), 416$ (Je), $485(\mathrm{Jy}), 561(\mathrm{Au}), 632(\mathrm{Se}), 706(\mathrm{Oc}), 776$ (No), 830 (De)

N(5)-Formyltetrahydrofolate see Citrovorum Factor

NNMR Tomography see Nuclear Magnetic Resonance

Noise

hospital-based helicopter, threat to hearing? [Pasic] $507(\mathrm{Au})$

Noise, Occupational see Noise

Mose

lhairy polyp, resident's page [Clegg] 634 (Se)

iinfections of paranasal sinuses and, in adult patients with immunodeficiency [Karlsson] 290 (My)

iinverted papilloma, considerations in treatment [Woodson] 806 (De)

llaryngeal perichondritis and abscess [Souliere] $481(\mathrm{Jy})$

Imisuse in terminology (letter) [Johnson] (reply) [Bailey] 485 (Jy)
Noise-Continued

new twist in nasal tip surgery, alternative to Goldman tip for wide or bulbous lobule [ $\mathrm{McCol}$ lough] $524(\mathrm{Au})$

'note flap' [Walike] 430 (Jy)

reconstruction of large nasal defects with subcutaneous pedicle nasolabial flap, underutilized technique [Levine] 628 (Se)

rhinocerebral mucormycosis, resident's page [Walker] 276 (Ap)

scale for evaluating results of rhinoplasty [Anderson] $520(\mathrm{Au})$

surgical anatomy of septorhinoplasty [Lessard] 25 (Ja)

trapdoor effect in nasolabial flaps, causes and corrections [Koranda] $421(\mathrm{Jy})$

Nose Neoplasms

intranasal composite grafts for dorsal support [Conley] 241 (Ap)

intranasal dermal analogue tumor (membranous basal cell adenoma), ultrastructure and immunohistochemistry [Zarbo] 333 (My)

Nuclear Magnetic Resonance

congenital cholesteatoma of petrous pyramid [Horn] 621 (Se)

effects of magnetic resonance imaging fields on stapedectomy prostheses [Applebaum] 820 (De)

magnetic resonance imaging vs computed tomography, comparison in imaging oral cavity and pharyngeal carcinomas [Schaefer] 730 (No)

Obesity

diagnosis and management of obstructive sleep apnea, multidisciplinary approach [Orr] 583 (Se)

predicting response to tongue retaining device for sleep apnea syndrome [Cartwright] 385 (Je)

Odontogenic Cysts

keratocyst, resident's page [Dierks] 346 (My)

Office Management

computer-based method of filing photographs and procedures [Allan] $178(\mathrm{Mr})$

Olfactory Bulb

olfactory marker protein in human olfactory pathway [Nakashima] 294 (My)

Olfactory Mucosa

epithelia, electron microscopy of, in 2 patients with anosmia [Moran] $122(\mathrm{Fe})$

Olfactory Pathways

human, olfactory marker protein in [Nakashima] 294 (My)

Oncocytoma see Adenoma

Ondine's Curse see Sleep Apnea Syndromes

Ophthalmoplegia

total, after internal maxillary artery ligation [Beall] 696 (Oc)

Orbit

medial orbital blow-out fracture with entrapment [Rauch] 53 (Ja)

total ophthalmoplegia after internal maxillary artery ligation [Beall] $696(\mathrm{Oc})$

Orbital Fractures see Skull Fractures

atypical facial pain and [Ruff] $338(\mathrm{My})$

osteoblastoma (letter) [Osguthorpe] $208(\mathrm{Mr})$

Organ of Corti

auditory evoked potential alterations induced by pulsed ultrasound [Moore] $309(\mathrm{My})$

Oropharynx

antral choanal polyp, resident's page [Clegg] 634 (Se)

diagnosis and management of obstructive sleep apnea, II. [Moran] 650 (Oc)

Osteogenesis

in vascularized periosteum, interactions with underlying bone [Canalis] $511(\mathrm{Au})$

Osteoma, Osteod

osteoblastoma (letter) [Osguthorpe] 208 (Mr)
Osteomyelitis

tuberculous petrous apicitis [Kearns] 406 (Je)

Osteophytosis, Spinal see Spinal Osteophytosis

Osteoradionecrosis see Radiation Injuries

Otalgia see Earache

Otitis Media

at Canyon Day, Ariz, 16-year follow-up in Apache Indians [Todd] 606 (Se)

chronic, surgery in elderly patients with [Vartiainen] $509(\mathrm{Au})$

eustachian tube function in chinchilla [Doyle] 305 (My)

experimental purulent, due to Streptococcus pneumoniae, sensorineural hearing loss in [Morizono] 794 (De)

prevention of hearing impairment from infection and ototoxic drugs [Catlin] 377 (Je)

recurrent, brain-stem evoked response waveform variation associated with [Lenhardt] $315(\mathrm{My})$

secretory, study of mucus glycoproteins in [Brown] $688(\mathrm{Oc})$

ventilating tubes (letters) [Healy, Levine] 416 (Je)

with effusion, hearing acuity of children with [Fria] $10(\mathrm{Ja})$

with effusion, role of allergy in pathogenesis of [Doyle] $502(\mathrm{Au})$

Otolaryngology

challenge to, deafness [Bailey] 1 (Ja)

diagnosis and management of obstructive sleep apnea, II. [Moran] 650 (Oc)

metabolic facial paralysis in infant [Sillman] 822 (De)

photodynamic therapy in otolaryngology-head and neck surgery [Keller] 758 (No)

residency programs, allergy and immunology training in [Osguthorpe] 779 (De)

use of butyl-2-cyanoacrylate in rabbit auricular cartilage [Fung] 459 (Jy)

Otosclerosis

carbon dioxide laser stapedotomy, thermal effects in vestibule [Coker] 601 (Se)

Otospongiosis see Otosclerosis

\section{$\mathbf{P}$}

Pain

atypical facial, and orbital cancer [Ruff] 338 (My)

auricular perichondritis secondary to acupuncture [Davis] 770 (No)

Palatal Neoplasms

treatment and prognosis of mucoepidermoid carcinoma in pediatric age group [Conley] 322 (My)

Palate

extended palatal island mucoperiosteal flap [Gullane] $330(\mathrm{My})$

indications for palatopharyngoplasty [deBerryBorowiecki] 659 (Oc)

iridium-192 implants in treatment of tonsillar region malignancies [Puthawala] 812 (De)

total ophthalmoplegia after internal maxillary artery ligation [Beall] 696 (Oc)

Palatopharyngeal Incompetence see Velopharyngeal Insufficiency

Palliative Treatment

amino-oxyacetic acid as, in tinnitus [Reed] 803 (De)

\section{Papilloma}

interferon therapy for bronchial papillomatosis controlled by papillomavirus-DNA hybridization [Ikenberg] 96 (Fe)

inverted, considerations in treatment [Woodson] 806 (De)

Papillomaviruses

interferon therapy for bronchial papillomatosis controlled by papillomavirus-DNA hybridization [Ikenberg] 96 (Fe)

verrucous carcinoma of larynx, possible human papillomavirus etiology [Abramson] 709 (No) 
Paradoxical Sleep see Sleep, REM

Paranasal Sinus Diseases

functional endoscopic sinus surgery, theory and diagnostic evaluation [Kennedy] 576 (Se)

Paranasal Sinus Neoplasms

use of malar bone graft to augment skull-base access [Mann] $30(\mathrm{Ja})$

Paranasal Sinuses

functional endoscopic sinus surgery, technique [Kennedy] 643 (Oc)

infections of nose and, in adult patients with immunodeficiency [Karlsson] $290(\mathrm{My})$

Paresthesia

hidrocystoma of apocrine gland derivation, resident's page [Hagan] 772 (No)

Parietal Bone

calvarial grafts for midface rehabilitation [Cinberg] $434(\mathrm{Jy})$

Parotid Gland

branchial cleft cyst, resident's page [Tami] 204 (Mr)

chondrocalcinosis of temporomandibular joint, pseudotumor of [Zemplenyi] 403 (Je)

\section{Parotid Neoplasms}

cytoskeletal proteins in oncocytic tumors [Gustafsson] $99(\mathrm{Fe})$

facial nerve palsy associated with Warthin's tumor [Lesser] $548(\mathrm{Au})$

management of ear canal in head and neck surgery [Conley] $90(\mathrm{Fe})$

pleomorphic adenoma and metastatic squamous cell carcinoma, resident's page [Atiyah] 204 (Mr)

treatment and prognosis of mucoepidermoid carcinoma in pediatric age group [Conley] 322 (My)

tumors of parapharyngeal space [Shoss] 753 (No)

unilocular cystic sebaceous lymphadenoma [Merwin] 273 (Ap)

Pectoralis Muscles

expansion of myocutaneous flaps [Forte] 371 (Je)

major, oral cavity reconstruction using amnion and [Lawson] 230 (Ap)

pectoralis myocutaneous flap modifications (letter) [Stiernberg] $208(\mathrm{Mr})$

pharyngoesophageal reconstruction (letter) [Goepfert] (reply) [Robertson] 706 (Oc)

pharyngoesophageal reconstruction, is skin-lined pharynx necessary? [Robertson] $375(\mathrm{Je})$

Penicillin G

sensorineural hearing loss in experimental purulent otitis media due to Streptococcus pneumoniae [Morizono] 794 (De)

Penicillin G, Procaine see Penicillin G

Penicillins

Kaposi's sarcoma in patient with AIDS, resident's page [Lanser] 486 (Jy)

Periosteum

extended palatal island mucoperiosteal flap [Gullane] $330(\mathrm{My})$

vascularized, osteogenesis in, interactions with underlying bone [Canalis] 511 (Au)

Peripheral Nerves

use of polytetrafluorinated ethylene compound in peripheral nerve grafting, an experimental study [Rice] $259(\mathrm{Ap})$

Peritonitis

Clostridium difficile colitis following head and neck surgery, case reports [Griebie] $550(\mathrm{Au})$

Pertussis see Whooping Cough

Petrolatum

approach to large nasoseptal perforations and attendant deformity [Belmont] $450(\mathrm{Jy})$

Petroleum Jelly see Petrolatum

Petrous Bone

congenital cholesteatoma of petrous pyramid

[Horn] 621 (Se)

tuberculous petrous apicitis [Kearns] $406(\mathrm{Je})$

Petrous Pyramid see Petrous Bone
Pharmacotherapy see Drug Therapy

Pharynectomy

fibromatosis and fibrosarcoma of larynx and pharynx in infant [McIntosh] $478(\mathrm{Jy})$

Pharyngeal Neoplasms

combined functional oral rehabilitation after radical cancer surgery [Wurster] $530(\mathrm{Au})$

pharyngeal wall, reappraisal after comparison of treatment methods [Marks] $79(\mathrm{Fe})$

squamous cell carcinoma of head and neck in patients under 40 years of age [Mendez] 762 (No)

\section{Pharyngectomy}

near-total pharyngeal reconstruction by 'rotarydoor' sternohyoid myocutaneous flap in dog, preliminary report [Broniatowski] 673 (Oc)

pharyngeal wall cancer, reappraisal after comparison of treatment methods [Marks] 79 (Fe)

\section{Pharyngitis}

antral choanal polyp, resident's page [Clegg] 634 (Se)

Pharynx

fibromatosis and fibrosarcoma of larynx and, in infant [McIntosh] 478 (Jy)

indications for palatopharyngoplasty [deBerryBorowiecki] 659 (Oc)

magnetic resonance imaging vs computed tomography, comparison in imaging oral cavity and pharyngeal carcinomas [Schaefer] 730 (No)

near-total pharyngeal reconstruction by 'rotarydoor' sternohyoid myocutaneous flap in dog, preliminary report [Broniatowski] $673(\mathrm{Oc})$

pectoralis myocutaneous flap modifications (letter) [Stiernberg] $208(\mathrm{Mr})$

pharyngoesophageal reconstruction (letter) [Goepfert] (reply) [Robertson] 706 (Oc)

pharyngoeosophageal reconstruction using free jejunal interposition grafts [Fisher] $747(\mathrm{No})$

pharyngoesophageal reconstruction, is skin-lined pharynx necessary? [Robertson] 375 (Je)

reconstruction options for pharyngeal and/or cervical esophageal defects [Schuller] 193 (Mr)

tumors of parapharyngeal space [Shoss] 753 (No)

Phonation see Voice

Phonation Disorders see Voice Disorders

Photochemotherapy

advances in laser skin surgery for vascular lesions [Keller] $437(\mathrm{Jy})$

photodynamic therapy in otolaryngology-head and neck surgery [Keller] 758 (No)

Photodynamic Therapy see Photochemotherapy

\section{Photography}

computer-based method of filing photographs and procedures [Allan] $178(\mathrm{Mr})$

profile analysis in facial plastic surgery [Larrabee] $682(\mathrm{Oc})$

scale for evaluating results of rhinoplasty [Anderson] 520 (Au)

Photomicrography

angiofollicular lymphoid hyperplasia, hyaline vascular variant (giant lymph node hyperplasia [GLNH], Castleman's disease), resident's page [Schroeder] 772 (No)

\section{Phototherapy}

photodynamic therapy in head and neck cancer [Schuller] $351(\mathrm{Je})$

Physician-Patient Relations

give priceless gift this year [Bailey] 777 (De)

Physics

comparative assessment of blood flow to canine island flaps [Silverman] $677(\mathrm{Oc})$

Pigs see Swine

Pituitary Gland

external rhinoplasty approach to transsphenoidal hypophysectomy [Koltai] 456 (Jy)

Platelets see Blood Platelets
Pneumothorax

complications of Venturi jet ventilation during microlaryngeal surgery [O'Sullivan] 127 (Fe)

Pollen

role of allergy in pathogenesis of otitis media with effusion [Doyle] $502(\mathrm{Au})$

Polyethylene Glycols

circulating immunocomplexes and laryngeal carcinoma [Denaro] 595 (Se)

Polyethylenes

porus, in reconstructive head and neck surgery [Berghaus] $154(\mathrm{Mr})$

Polytetrafluorethylene

use of polytetrafluorinated ethylene compound in peripheral nerve grafting, an experimental study [Rice] 259 (Ap)

Postoperative Complications

complications of Venturi jet ventilation during microlaryngeal surgery [O'Sullivan] $127(\mathrm{Fe})$

nasopharyngeal stenosis [Cotton] $146(\mathrm{Mr})$

Postoperative Period see Surgery, Operative

Posture

auditory response to inverted posture (letter)

[Plocher] $135(\mathrm{Fe})$

predicting response to tongue retaining device for sleep apnea syndrome [Cartwright] 385 (Je)

Presbycusis see Hearing Loss, Sensorineural

\section{Pressure}

electrocochleography and symptoms of inner ear dysfunction [Ferraro] 71 (Fe)

eustachian tube function in chinchilla [Doyle] 305 (My)

morning, in middle ear [Hergils] 86 (Fe)

Prognosis

and treatment of mucoepidermoid carcinoma in pediatric age group [Conley] 322 (My)

prognostic determination and submandibular function in Bell's palsy, dynamic testing with technetium Tc 99m [Yamashita] 244 (Ap)

squamous cell carcinoma of head and neck in patients under 40 vears of age [Mendez] 762 (No)

Propranolol

dangers of withdrawal of, prior to local anesthesia with epinephrine (letter) [Alexander] 280 (Ap)

Prostacyclins see Prostaglandins $X$

Prostaglandins

and other metabolites of arachidonic acid [Poole] $317(\mathrm{My})$

Prostaglandins I see Prostaglandins $X$

Prostaglandins 12 see Prostaglandins $X$

Prostaglandins $X$

prostaglandins and other metabolites of arachidonic acid [Poole] $317(\mathrm{My})$

Prosthesis

deterioration of voice prostheses caused by fungal vegetations (letter) [Mahieu] 280 (Ap)

effects of magnetic resonance imaging fields on stapedectomy prostheses [Applebaum] 820 (De)

expansion of myocutaneous flaps [Forte] 371 (Je)

tracheoesophageal puncture (letter) [Blom] 208, (reply) [Weinberg] $209(\mathrm{Mr}$ )

Protein, $\mathbf{S 1 0 0}$

intranasal dermal analogue tumor (membranous basal cell adenoma), ultrastructure and immunohistochemistry [Zarbo] 333 (My)

Proteins

olfactory marker, in human olfactory pathway [Nakashima] 294 (My)

Pseudogout see Chondrocalcinosis

Ptosis, Eyelid see Blepharoptosis

Public Health

otitis media at Canyon Day, Ariz, 16-year followup in Apache Indians [Todd] 606 (Se)

patterns of use and incidence of smokeless tobacco consumption in school-age children [Schaefer] $639(\mathrm{Oc})$ 
Public Health - Continued

smokeless tobacco, open letter to Surgeon Gener-

al [Bailev] 707 (No)

we must stop selling cancer to our children

[Bailey] 637 (Oc)

Public Health Service (US) see United States

Public Health Service

Pulmonary Neoplasms see Lung Neoplasms

PUVA Therapy see Photochemotherapy

\section{$\mathbf{R}$}

Rabbits

auricular cartilage, use of butyl-2-cyanoacrylate in [Fung] 459 (Jy)

Radiation Dosage see Radiotherapy Dosage

Radiation Effects

verrucous carcinoma of larynx, possible human papillomavirus etiology [A bramson] 709 (No)

Radiation Injuries

iridium-192 implants in treatment of tonsillar region malignancies [Puthawala] 812 (De)

mandibular reconstruction with $\mathrm{A}-\mathrm{O}$ plate [Hilger] 469 (Jy)

\section{Radical Neck Dissection}

and combined therapy, study of effectiveness [DeSanto] 366 (Je)

cervical lymph node metastases, incidence and implications of extracapsular carcinoma [Johnson] $534(\mathrm{Au})$

irradiation after (letters) [Blitzer, Vikram] 827 (reply) [DeSanto] 828 (De)

Radiography

antral choanal polyp, resident's page [Clegg] 634 (Se)

functional endoscopic sinus surgery, technique [Kennedy] $643(\mathrm{Oc})$

hairy polyp, resident's page [Clegg] 634 (Se)

intramuscular myxoma of neck [Nishijima] 699 (Oc)

inverted papilloma, considerations in treatment [Woodson] 806 (De)

morning pressure in middle ear [Hergils] 86 ( $\mathrm{Fe})$

neuroendocrine carcinoma of skin (Merkel's cell tumor, trabecular carcinoma of skin), resident's page [Walker] $702(\mathrm{Oc})$

pleomorphic adenoma, resident's page [Welsh] $558(\mathrm{Au})$; correction, 708 (No)

role of endoscopy in evaluating patients with head and neck cancer, multi-institutional prospective study [Leipzig] 589 (Se)

twisted larynx, clinical syndrome (letter) [Lewy] (ed. reply) [Bailey] 557 ( $\mathrm{Au})$

Radioisotope Scanning see Radionuclide Imaging

Radiology

functional endoscopic sinus surgery, theory and diagnostic evaluation [Kennedy] 576 (Se)

magnetic resonance imaging vs computed tomography, comparison in imaging oral cavity and pharyngeal carcinomas [Schaefer] 730 (No)

Radiology, Diagnostic X-Ray see Radiography

Radionuclide Imaging

prognostic determination and submandibular function in Bell's palsy, dynamic testing with technetium Tc 99m [Yamashita] 244 (Ap)

Radiotherapy

caurbon dioxide laser stapedotomy, thermal effects in vestibule [Coker] 601 (Se)

cervical lymph node metastases, incidence and implications of extracapsular carcinoma [Johnson] $534(\mathrm{Au})$

cisplatic potentiation of, long-term follow-up [Leipzig] $114(\mathrm{Fe})$

conservation laryngeal surgery, critical analysis [Maceri] 361 (Je)

definite vs adjuvant, comparative effects on lymphocyte subpopulations in patients with head and neck squamous carcinoma [Wolf] 716 (No)
Radiotherapy-Continued

iridium-192 implants in treatment of tonsillar region malignancies [Puthawala] $812(\mathrm{De})$

irradiation after neck dissection (letters) [Blitz er, Vikram] 827 (reply) [DeSanto] 828 (De)

laryngeal perichondritis and abscess [Souliere] 481. (Jy)

magnetic resonance imaging vs computed tomography, comparison in imaging oral cavity and pharyngeal carcinoma [Schaefer] 730 (No)

maintenance chemotherapy for high-risk patients, preliminary report [Johnson] 727 (No)

neck dissection and combined therapy, study of effectiveness [DeSanto] 366 (Je)

pharyngeal wall cancer, reappraisal after comparison of treatment methods [Marks] 79 ( $\mathrm{Fe})$

photodynamic therapy in otolaryngology-head and neck surgery [Keller] 758 (No)

primary CNS lymphoma in cerebellopontine angle [Ierokomos] 50 (Ja)

Osquamous cell carcinoma of head and neck in patients under 40 years of age [Mendez] $76{ }^{\circ}$ (No)

verrucous carcinoma of larynx, possible human papillomavirus etiology [Abramson] 709 (No)

with concomitant mitomycin and fluorouracil in head and neck cancer [Kaplan] 220 (Ap)

Radiotherapy Dosage

definite vs adjuvant radiotherapy, comparative effects on lymphocyte subpopulations in patients with head and neck squamous carcinoma [Wolf] 716 (No)

Rapid Eye Movements see Sleep, REM

Rats

nerve grafting, functional results after primary vs delayed repair [Ellis] 781 (De)

\section{Records}

computer-based method of filing photographs and procedures [Allan] $178(\mathrm{Mr})$

Recurrence see Disease

Rehabilitation

Blom-Singer speech, long-term results of procedure [Wetmore] $106(\mathrm{Fe})$

Reoperation see Surgery, Operative

Research Design

irradiation after neck dissection (letters) [Blitz er, Vikram] 827 (reply) [DeSanto] 828 (De)

patterns of use and incidence of smokeless tobacco consumption in school-age children [Schaef er] 639 (Oc)

scale for evaluating results of rhinoplasty [Anderson] $520(\mathrm{Au})$

Residency, Medical see Internship and Residency

\section{RESIDENT'S PAGE}

66 (Ja), 136 (Fe), $204(\mathrm{Mr}), 276$ (Ap), 346 (My), 412 (Je), $486(\mathrm{Jy}), 558(\mathrm{Au})$, correction, $708(\mathrm{No})$, 634 (Se), 702 (Oc), 772 (No)

Respiration

morning pressure in middle ear [Hergils] 86 (Fe)

\section{Respiration, Artificial}

complications of Venturi jet ventilation during microlaryngeal surgery [O'Sullivan] $127(\mathrm{Fe})$

inhalation of carbon dioxide mixtures for sensorineural deafness, evaluation of rebreathing method [Freeman] $75(\mathrm{Fe})$

Respiratory Tract Infections

of nose and paranasal sinuses in adult patients with immunodeficiency [Karlsson] $290(\mathrm{My})$

Rhabdomyoma

adult, resident's page [Brown] $486(\mathrm{Jy})$

Rheology

study of mucus glycoproteins in secretory otitis media [Brown] 688 (Oc)

Rhinitis

approach to large nasoseptal perforations and attendant deformity [Belmont] $450(\mathrm{Jy})$
Rhinitis, Allergic, Perennial

laser turbinectomy as adjunct to rhinoseptoplasty [Selkin] 446 (Jy)

Rhinitis, Vasomotor

laser turbinectomy as adjunct to rhinoseptoplasty [Selkin] $446(\mathrm{Jy})$

Rhinoplasty

augmentation, enbucrilate as cartilage adhesive in [Sachs] $389(\mathrm{Je})$

external, approach to transsphenoidal hypophysectomy [Koltai] 456 (Jy)

laser turbinectomy as adjunct to rhinoseptoplasty [Selkin] $446(\mathrm{Jy})$

new twist in nasal tip surgery, alternative to Goldman tip for wide or bulbous lobule [McCollough] $524(\mathrm{Au})$

scale for evaluating results of [Anderson] 520 ( Au)

surgical anatomy of septorhinoplasty [Lessard] $25(\mathrm{Ja})$

Rhombencephalic Sleep see Sleep, REM

Roentgenography see Radiography

Roentography

indications for palatopharyngoplasty [deBerry-

Borowiecki] 659 (Oc)

Rubber, Silicone see Silicone Elastomers

Rubella

prevention of hearing impairment from infection and ototoxic drugs [Catlin] 377 (Je)

Rubeola see Measles

$\mathbf{S}$

\section{Saline see Sodiun Chloride}

Saliva

prognostic determination and submandibular

function in Bell's palsy, dynamic testing with technetium Tc 99m [Yamashita] 244 (Ap)

Salivary Gland Neoplasms

acquired immune deficiency syndrome-related lymphadenopathies presenting in salivary gland lymph nodes [Ryan] 554 (Au)

intranasal dermal analogue tumor (membranous basal cell adenoma), ultrastructure and immunohistochemistry [Zarbo] 333 (My)

malignant, of base of tongue [Kessler] 664 (Oc)

mucocele of submandibular gland [Surkin] 623 (Se)

tumors of parapharyngeal space [Shoss] 753 (No)

Salmonella Infections

Salmonella dublin neck abscess [Bello] 476 (Jy)

Sarcoma

synovial, of tongue base, 7th reported case [Holtz] 271 (Ap)

Sarcoma, Kaposi's

angiofollicular lymphoid hyperplasia, hyaline vascular variant (giant lymph node hyperplasia [GLNH], Castleman's disease), resident's page [Schroeder] 772 (No)

in patient with AIDS, resident's page [Lanser] $486(\mathrm{Jy})$

Scanning, Radioisotope see Radionuclide Imaging

\section{Sciatic Nerve}

nerve grafting, functional results after primary vs delayed repair [Ellis] 781 (De)

use of polytetrafluorinated ethylene compound in peripheral nerve grafting, an experimental study [Rice] 259 (Ap)

Scintigraphy see Radionuclide Imaging

Sclerosis, Disseminated see Multiple Sclerosis

Sebaceous Glands

unilocular cystic sebaceous lymphadenoma of parotid gland [Merwin] 273 (Ap)

Seizures

cardiopulmonary arrest due to misuse of viscous lidocaine [Puczynski] 768 (No)

Sella Turcica

external rhinoplasty approach to transsphenoidal hypophysectomy [Koltai] $456(\mathrm{Jy})$ 
Sialography

adult rhabdomyoma, resident's page [Brown] 486 (Jy)

\section{Siamang see Hylobates}

Silastics see Silicone Elastomers

Silicone Elastomers

autograft frontoplasty, simple technique for correction of post-osteoplastic flap defects [Myers] 626 (Se)

osteogenesis in vascularized periosteum, interactions with underlying bone [Canalis] 511 (Au) support of unstable nasal fractures with silicone rubber wedge splints [Colclasure] $443(\mathrm{Jy})$

\section{Silicones}

injectable liquid silicone (letter) [Aronsohn] (reply) [Kamer] $70(\mathrm{Ja})$

\section{Silver Nitrate}

endolymphatic hydrops in guinea pigs after cauterizing sac with [Yazawa] 301 (My)

Sinus Thrombosis

lateral, medical or surgical treatment? [Goldenberg] $56(\mathrm{Ja})$

Sinusitis

functional endoscopic sinus surgery, technique [Kennedy] $643(\mathrm{Oc})$

\section{Skeletin see Desmin}

Skin

advances in laser skin surgery for vascular lesions [Keller] 437 ( Jy)

measurement of alternative blood flow in porcine panniculus carnosus myocutaneous flap [Cummings] 598 (Se)

near-total pharyngeal reconstruction by 'rotarydoor' sternohyoid myocutaneous flap in dog, preliminary report [Broniatowski] 673 (Oc)

pharyngoesophageal reconstruction (letter) [Goepfert] (reply) [Robertson] 706 (Oc)

pharyngoesophageal reconstruction, is skin-lined pharynx necessary? [Robertson] 375 (Je)

\section{Skin Absorption}

skin wound approximation with new absorbable suture material [Webster] $517(\mathrm{Au})$

\section{Skin Neoplasms}

neuroendocrine carcinoma of skin (Merkel's cell tumor, trabecular carcinoma of skin), resident's page [Walker] 702 (Oc)

Skin Transplantation

expansion of myocutaneous flaps [Forte] 371 (Je)

extension of musculocutaneous flap by surgical delay [Haughey] 234 (Ap)

mandible reconstruction with trapezius osteomusculocutaneous flap [Panje] 223 (Ap)

pectoralis myocutaneous flap modifications (letter) [Stiernberg] $208(\mathrm{Mr})$

skin wound approximation with new absorbable suture material [Webster] $517(\mathrm{Au})$

survival of myocutaneous flaps, experimental evaluation by intra-arterial injection of dye [Nieto] 43 (Ja)

trapezius osteomyocutaneous flap for mandibular reconstruction [Gregor] $198(\mathrm{Mr})$

\section{Skull}

porous polyethylene in reconstructive head and neck surgery [Berghaus] $154(\mathrm{Mr})$

use of malar bone graft to augment skull-base access [Mann] $30(\mathrm{Ja})$

\section{Skull Fractures}

calvarial grafts for midface rehabilitation [Cinberg] $434(\mathrm{Jy})$

malar fractures associated with exophthalmos [Godoy] $174(\mathrm{Mr})$

medial orbital blow-out fracture with entrapment [Rauch] $53(\mathrm{Ja})$

Sleep Apnea Syndromes

diagnosis and management of obstructive sleep apnea, multidisciplinary approach [Orr] 583 (Se)

indications for palatopharyngoplasty [deBerryBorowiecki] $659(\mathrm{Oc})$

obstructive, diagnosis and management of, II.
Sleep Apnea Syndromes-Continued

[Moran] $650(\mathrm{Oc})$

predicting response to tongue retaining device for [Cartwright] 385 (Je)

Sleep, REM

diagnosis and management of obstructive sleep apnea, multidisciplinary approach [Orr] 583 (Se)

Smoking

give priceless gift this year [Bailey] 777 (De)

histoplasmosis of tonsil, resident's page [Davis] $558(\mathrm{Au})$

patterns of use and incidence of smokeless tobacco consumption in school-age children [Schaefer] $639(\mathrm{Oc})$

Warthin's tumor arising in lymph node containing heterotopic salivary gland, resident's page [Cannon] $702(\mathrm{Oc})$

we must stop selling cancer to our children [Bailey] $637(\mathrm{Oc})$

\section{Snoring}

diagnosis and management of obstructive sleep apnea, multidisciplinary approach [Orr] 583 (Se); II. [Moran] 650 (Oc)

indications for palatopharyngoplasty [deBerryBorowiecki] 659 (Oc)

\section{Socioeconomic Factor}

patterns of use and incidence of smokeless tobacco consumption in school-age children [Schaefer] $639(\mathrm{Oc})$

\section{Sodium Chloride}

treatment of Meniere's disease by intratympanic injection with lidocaine [Fradis] $491(\mathrm{Au})$

twisted larynx, clinical syndrome (letter) [Lewy] (ed. reply) [Bailey] $557(\mathrm{Au})$

Sonication see Ultrasonics

Sore Throat see Pharyngitis

Speech, Alaryngeal

acceptability and intelligibility of tracheoesophageal speech [Tardy-Mitzell] 213 (Ap)

deterioration of voice prostheses caused by fungal vegetations (letter) [Mahieu] 280 (Ap)

differences in speaking proficiencies in 3 laryngectomee groups [Williams] $216(\mathrm{Ap})$

improved esophageal insufflation test [Blom] 211 (Ap)

long-term results of Blom-Singer speech rehabilitation procedure [Wetmore] $106(\mathrm{Fe})$

neoglottic reconstruction following total laryngectomy [Tanabe] $39(\mathrm{Ja})$

primary voice restoration at laryngectomy $[\mathrm{Ha}$ maker] $182(\mathrm{Mr})$

tracheal stoma reconstruction [Panje] $190(\mathrm{Mr})$

tracheoesophageal puncture prostheses (letter)

[Blom] 208, (reply) [Weinberg] $209(\mathrm{Mr}$ )

Speech, Esophageal see Speech, Alaryngeal

Sphenoid Sinus

congenital cholesteatoma of petrous pyramid [Horn] 621 (Se)

external rhinoplasty approach to transsphenoidal hypophysectomy [Koltai] 456 (Jy)

functional endoscopic sinus surgery, technique [Kennedy] 643 (Oc)

Spinal Osteophytosis

dysphagia and Forestier's disease [Deutsch] 400 (Je)

Spiral Organ see Organ of Corti

Spirochaetales Infections

facial palsy (letter) [Asbrink] 349 (My)

Spondylosis Deformans see Spinal Osteophytosis

Sports

wrestler's ear (acute auricular hematoma) [Giffin] $161(\mathrm{Mr})$

Staging, Neoplasm see Neoplasm Staging

Stains and Staining

comparative assessment of blood flow to canine island flaps [Silverman] $677(\mathrm{Oc})$

DNA content of human squamous cell carcinoma cell lines, analysis by flow cytometry and chromosome enumeration [Roa] 565 (Se)
Stains and Staining - Continued

large cholesterol granuloma cysts in mastoid clinical and histopathologic findings [Palva] 786 (De)

neuroendocrine carcinoma of skin (Merkel's cell tumor, trabecular carcinoma of skin), resident's page [Walker] 702 (Oc)

\section{Stapes see Ear Ossicles}

Stapes Surgery

carbon dioxide laser stapedotomy, thermal effects in vestibule [Coker] 601 (Se)

effects of magnetic resonance imaging fields on stapedectomy prostheses [Applebaum] 820 (De)

\section{Statistics}

definite vs adjuvant radiotherapy, comparative effects on lymphocyte subpopulations in patients with head and neck squamous carcinoma [Wolf] 716 (No)

irradiation after neck dissection (letters) [Blitzer, Vikram] 827 (reply) [DeSanto] 828 (De)

patterns of use and incidence of smokeless tobacco consumption in school-age children [Schaefer] 639 (Oc)

we must stop selling cancer to our children [Bailey] 637 (Oc)

Stem Cell Assay, Tumor see Tumor Stem Cell Assay

Sternum

near-total pharyngeal reconstruction by 'rotarydoor' sternohyoid myocutaneous flap in dog preliminary report [Broniatowski] $673(\mathrm{Oc})$

Stomach

laryngeal perichondritis and abscess [Souliere] $481(\mathrm{Jy})$

Streptococcus pneumoniae

role of allergy in pathogenesis of otitis media with effusion [Doyle] $502(\mathrm{Au})$

sensorineural hearing loss in experimental purulent otitis media due to [Morizono] 794 (De)

Subclavian Artery

dynamic computed tomography, assessment of vascular malformations and angiofibroma [Hill] $62(\mathrm{Ja})$

Submandibular Gland

adult rhabdomyoma, resident's page [Brown] 486 (Jy)

mucocele of [Surkin] 623 (Se)

prognostic determination and function of in Bell's palsy, dynamic testing with technetium Tc 99 m [Yamashita] 244 (Ap)

Submandibular Gland Neoplasms see Salivary Gland Neoplasms

Submaxillary Gland see Submandibular Gland

Substance Dependence

give priceless gift this year [Bailey] 777 (De) Surgery, Operative

cervical mycobacterial lymphadenitis, medical vs surgical management [Castro] 815 (De)

Clostridium difficile colitis following head and neck surgery, case reports [Griebie] 550 (Au)

functional endoscopic sinus surgery, theory and diagnostic evaluation [Kennedy] 576 (Se)

functional endoscopic sinus, technique [Kennedy] $643(0 \mathrm{c})$

inverted papilloma, considerations in treatment [Woodson] 806 (De)

iridium-192 implants in treatment of tonsillar region malignancies [Puthawala] 812 (De)

large cholesterol granuloma cysts in mastoid, clinical and histopathologic findings [Palva] 786 (De)

laser skin, for vascular lesions, advances in [Keller] $437(\mathrm{Jy})$

laser turbinectomy as adjunct to rhinoseptoplasty [Selkin] $446(\mathrm{Jy})$

maintenance chemotherapy for high-risk patients, preliminary report [Johnson] 727 (No)

malignant salivary gland tumors of base of tongue [Kessler] $664(\mathrm{Oc})$

modified neck dissection for metastatic testicu- 
Surgery, Operative - Continued

lar carcinoma [Zeph] $667(\mathrm{Oc})$

near-total pharyngeal reconstruction by 'rotarydoor' sternohyoid myocutaneous flap in dog, preliminary report [Broniatowski] $673(\mathrm{Oc})$

photodynamic therapy in otolaryngology-head and neck surgery [Keller] 758 (No)

squamous cell carcinoma of head and neck in patients under 40 years of age [Mendez] 762 (No)

surgery in elderly patients with chronic otitis media [Vartiainen] 509 (Au)

Surgery, Plastic

aesthetic facial surgery in otolaryngology training program [Thomas] $141(\mathrm{Mr})$

autograft frontoplasty, simple technique for correction of post-osteoplastic flap defects [Myers] 626 (Se)

blepharoplasty, indications and preoperative assessment [Holt] 394 (Je)

calvarial grafts for midface rehabilitation [Cinberg] $434(\mathrm{Jy})$

combined functional oral rehabilitation after radical cancer surgery [Wurster] 530 ( $\mathrm{Au}$ )

extended palatal island mucoperiosteal flap [Gullane] 330 (My)

extension of musculocutaneous flap by surgical delay [Haughey] 234 (Ap)

facial, profile analysis in [Larrabee] $682(\mathrm{Oc})$

forehead lift (letter) [Chrisman] 827 (De)

forehead lift, review [Adamson] $325(\mathrm{My})$

injectable liquid silicone (letter) [Aronsohn] (reply) [Kamer] $70(\mathrm{Ja})$

intranasal composite grafts for dorsal support [Conley] 241 (Ap)

mandible reconstruction with trapezius osteomusculocutaneous flap [Panje] $223(\mathrm{Ap})$

mandibular reconstruction with $\mathrm{A}-\mathrm{O}$ plate [Hilger] 469 (Jy)

new twist in nasal tip surgery, alternative to Goldman tip for wide or bulbous lobule [McCollough] $524(\mathrm{Au})$

oblique forehead flap for total reconstruction of nasal tip and columella [Baker] 425 (Jy)

oral cavity reconstruction using pectoralis major muscle and amnion [Lawson] 230 (Ap)

pharyngoesophageal reconstruction (letter) [Goepfert] (reply) [Robertson] 706 (Oc)

pharyngoesophageal reconstruction using free jejunal interposition grafts [Fisher] 747 (No)

pharyngoesophageal reconstruction, is skin-lined pharynx necessary? [Robertson] 375 (Je)

porous polyethylene in reconstructive head and neck surgery [Berghaus] $154(\mathrm{Mr})$

reconstruction of half of face [Conley] $142(\mathrm{Mr})$

reconstruction of large nasal defects with subcutaneous pedicle nasolabial flap, underutilized technique [Levine] 628 (Se)

reconstruction options for pharyngeal and/or cervical esophageal defects [Schuller] 193 (Mr)

trapdoor effect in nasolabial flaps, causes and corrections [Koranda] $421(\mathrm{Jy})$

trapezius osteomyocutaneous flap for mandibular reconstruction [Gregor] $198(\mathrm{Mr})$

use of butyl-2-cyanoacrylate in rabbit auricular cartilage [Fung] 459 (Jy)

use of electrosurgery in blepharoplasty [Colton] 441 (Jy)

use of temporalis fascia in eyelid reconstruction [Holt] $165(\mathrm{Mr})$

westernization of Asian eyelid [Matsunaga] 149 $(\mathrm{Mr})$

\section{Surgical Flaps}

approach to large nasoseptal perforations and attendant deformity [Belmont] 450 (Jy)

autograft frontoplasty, simple technique for correction of post-osteoplastic flap defects [ $\mathrm{My}$ ers] $626(\mathrm{Se})$

comparative assessment of blood flow to canine island flaps [Silverman] $677(\mathrm{Oc})$
Surgical Flaps - Continued

expansion of myocutaneous flaps [Forte] 371 (Je)

extended palatal island mucoperiosteal flap [Gullane] $330(\mathrm{My})$

extension of musculocutaneous flap by surgical delay [Haughey] 234 (Ap)

management of ear canal in head and neck surgery [Conley] $90(\mathrm{Fe})$

mandible reconstruction with trapezius osteomusculocutaneous flap [Panje] 223 (Ap)

mandibular reconstruction with $\mathrm{A}-\mathrm{O}$ plate [Hilger] $469(\mathrm{Jy})$

measurement of alternative blood flow in porcine panniculus carnosus myocutaneous flap [Cummings] 598 (Se)

nasopharyngeal stenosis [Cotton] $146(\mathrm{Mr})$

near-total pharyngeal reconstruction by 'rotarydoor' sternohyoid myocutaneous flap in dog, preliminary report [Broniatowski] $673(\mathrm{Oc})$

'note flap' [Walike] 430 (Jy)

oblique forehead flap for total reconstruction of nasal tip and columella [Baker] $425(\mathrm{Jy})$

oral cavity reconstruction using pectoralis major muscle and amnion [Lawson] 230 (Ap)

pectoralis myocutaneous flap modifications (letter) [Stiernberg] $208(\mathrm{Mr})$

pharyngoesophageal reconstruction (letter) [Goepfert] (reply) [Robertson] 706 (Oc)

pharyngoesophageal reconstruction, is skin-lined pharynx necessary? [Robertson] 375 (Je)

reconstruction of large nasal defects with subcutaneous pedicle nasolabial flap, underutilized technique [Levine] 628 (Se)

reconstruction options for pharyngeal and/or cervical esophageal defects [Schuller] 193 (Mr)

survival of myocutaneous flaps, experimental evaluation by intra-arterial injection of dye [Nieto] $43(\mathrm{Ja})$

temporalis muscle-galea flap in facial reanimation [Mathog] $168(\mathrm{Mr})$

trapdoor effect in nasolabial flaps, causes and corrections [Koranda] $421(\mathrm{Jy})$

trapezius osteomyocutaneous flap for mandibular reconstruction [Gregor] $198(\mathrm{Mr})$

Sutures

new twist in nasal tip surgery, alternative to Goldman tip for wide or bulbous lobule [ $\mathrm{McCol}$ lough] $524(\mathrm{Au})$

skin wound approximation with new absorbable suture material [Webster] 517 (Au)

Swallowing see Deglutition

Sweat Glands

hidrocystoma of apocrine gland derivation, resident's page [Hagan] 772 (No)

Swine

measurement of alternative blood flow in porcine panniculus carnosus myocutaneous flap [Cummings] 598 (Se)

Symphalangus see Hylobates

\section{Synovial Membrane}

synovial sarcomas of tongue base, 7 th reported case [Holtz] 271 (Ap)

\section{Technetium}

prognostic determination and submandibular function in Bell's palsy, dynamic testing with Tc 99m [Yamashita] 244 (Ap)

Temporal Bone

findings in otopalatodigital syndrome [Shi] 119 (Fe)

tuberculous petrous apicitis [Kearns] 406 (Je)

Temporal Muscle see Masticatory Muscles

Temporomandibular Joint

chondrocalcinosis of, parotid pseudotumor [Zemplenyi] $403(\mathrm{Je})$

Tensor Tympani see Tympanic Membrane

Teratoma

modified neck dissection for metastatic testicular carcinoma [Zeph] 667 (Oc)
Testicular Neoplasms

modified neck dissection for metastatic testicular carcinoma [Zeph] $667(\mathrm{Oc})$

Tetanus

dysphagia as presenting symptom of [Wang] 342 (My)

Tetracyclines

osteogenesis in vascularized periosteum, interactions with underlying bone [Canalis] $511(\mathrm{Au}$

Texas

patterns of use and incidence of smokeless tobacco consumption in school-age children [Schaefer] $639(\mathrm{Oc})$

Throat see Pharynx

Thrombocytes see Blood Platelets

Thromboxanes

prostaglandins and other metabolites of arachidonic acid [Poole] $317(\mathrm{My})$

Thyroid Cartilage see Laryngeal Cartilages

Thyroid Neoplasms

DNA flow cytometry of [Kraemer] 34 (Ja)

Tick Paralysis see Tick Toxicoses

Tick Toxicoses

facial palsy (letter) [Asbrink] $349(\mathrm{My})$

Tinnitus

amino-oxyacetic acid as palliative in [Reed] 803 (De)

brain-stem auditory-evoked potentials during lidocaine infusion in humans [Ruth] 799 (De) counseling the patient with [Sweetow] 283 (My)

electrocochleography and symptoms of inner ear dysfunction [Ferraro] $71(\mathrm{Fe})$

management of patients with (letter) [Gates] 631 (reply) [Sweetow] 632 (Se)

treatment of Meniere's disease by intratympanic injection with lidocaine [Fradis] $491(\mathrm{Au})$

Tobacco see also Smoking

smokeless, open letter to Surgeon General [Bailey] 707 (No)

smokeless, patterns of use and incidence of consumption in school-age children [Schaefer] 639 (Oc)

Toes

temporal bone findings in otopalatodigital syndrome [Shi] $119(\mathrm{Fe})$

Tomography

modified neck dissection for metastatic testicular carcinoma [Zeph] $667(\mathrm{Oc})$

$\mathrm{X}$-linked progressive mixed deafness with perilymphatic gusher during stapes surgery [Cremers] 249 (Ap)

Tomography, NMR see Nuclear Magnetic Resonance

Tomography, Transmission Computed see Tomography, $\mathrm{X}$-Ray Computed

Tomography, X-Ray Computed

auditory brain-stem response in determination of brain death [Hall] 613 (Se)

changing concepts of acoustic neuroma diagnosis [Barrs] $17(\mathrm{Ja})$

dynamic, assessment of vascular malformations and angiofibroma [Hill] $62(\mathrm{Ja})$

dysphagia and Forestier's disease [Deutsch] 400 (Je)

functional endoscopic sinus surgery, theory and diagnostic evaluation [Kennedy] $576(\mathrm{Se})$

laryngeal cyst of thyroid cartilage [Burgess] 826 (De)

magnetic resonance imaging vs, comparison in imaging oral cavity and pharyngeal carcinomas [Schaefer] 730 (No)

medullary space involvement in laryngeal carcinoma, computed tomographic demonstration [Silverman] $541 \mathrm{(Au})$

mucocele of submandibular gland [Surkin] 623 (Se)

of cervical lymph nodes, staging and management of head and neck cancer [Stevens] 735 (No)

pathogenesis of protruded false vocal fold [Honjo] $398(\mathrm{Je})$ 
Tomography, X-Ray Computed-Continued

3-dimensional reconstruction of cochlear nuclear complex in humans [Terr] 495 (Au)

tumors of parapharyngeal space [Shoss] 753 (No)

Tongue

malignant salivary gland tumors of base of

[Kessler] 664 (Oc)

retaining device for sleep apnea syndrome, predicting response to [Cartwright] 385 (Je)

Tongue Neoplasms

oral lichen planus and squamous carcinoma, case report and literature update [Kaplan] 543 (Au)

synovial sarcomas of tongue base, 7 th reported case [Holtz] 271 (Ap)

Tonsil

airway obstruction in immunosuppressed child [Myer] 409 (Je)

histoplasmosis of, resident's page [Davis] 558 (Au)

peritonsillar abscess (letter) [Richardson] 135 (Fe)

Tonsillar Neoplasms

iridium-192 implants in treatment of tonsillar region malignancies [Puthawala] 812 (De)

localized amyloid deposit (amyloidoma), resident's page [Davis] 412 (Je)

Tonsillectomy

diagnosis and management of obstructive sleep apnea, II. [Moran] 650 (Oc)

nasopharyngeal stenosis [Cotton] $146(\mathrm{Mr})$

Tooth Mobility

oral features of Wegener's granulomatosis [Handlers] 267 (Ap)

Trachea

acceptability and intelligibility of tracheoesophageal speech [Tardy-Mitzell] 213 (Ap)

differences in speaking proficiencies in 3 laryngectomee groups [Williams] 216 (Ap)

improved esophageal insufflation test [Blom] 211 (Ap)

long-term results of Blom-Singer speech rehabilitation procedure [Wetmore] $106(\mathrm{Fe})$

neoglottic reconstruction following total laryngectomy [Tanabe] 39 (Ja)

primary voice restoration at laryngectomy [Hamaker] $182(\mathrm{Mr})$

tracheoesophageal puncture prostheses (letter)

[Blom] 208, (reply) [Weinberg] $209(\mathrm{Mr})$

Tracheal Neoplasms

carcinoma presenting as thyroid cyst [Vitug] 340 (My)

Tracheostomy see Tracheotomy

Tracheotomy

acceptability and intelligibility of tracheoesophageal speech [Tardy-Mitzell] 213 (Ap)

conservation laryngeal surgery, critical analysis

[Maceri] 361 (Je)

diagnosis and management of obstructive sleep apnea, multidisciplinary approach [Orr] 583 (Se); II. [Moran] 650 (Oc)

laser arytenoidectomy [Lim] $262(\mathrm{Ap})$

tracheal stoma reconstruction [Panje] $190(\mathrm{Mr})$

twisted larynx, clinical syndrome (letter) [Lewy] (ed. reply) [Bailey] $557(\mathrm{Au})$

\section{Transplantation}

liver, airway obstruction in immunosuppressed child [Myer] 409 (Je)

use of malar bone graft to augment skull-base access [Mann] 30 (Ja)

use of polytetrafluorinated ethylene compound in peripheral nerve grafting, an experimental study [Rice] 259 (Ap)

Transplantation, Autologous

autograft frontoplasty, simple technique for correction of post-osteoplastic flap defects $[\mathrm{My}$ ers] 626 (Se)

nerve grafting, functional results after primary vs delayed repair [Ellis] 781 (De)

reconstruction of large nasal defects with subcu-
Transplantation, Autologous-Continued taneous pedicle nasolabial flap, underutilized technique [Levine] 628 (Se)

use of butyl-2-cyanoacrylate in rabbit auricular cartilage [Fung] 459 (Jy)

Trauma see Wounds and Injuries

Triamcinolone Acetonide

trapdoor effect in nasolabial flaps, causes and corrections [Koranda] 421 (Jy)

Trismus

dysphagia as presenting symptom of tetanus [Wang] $342(\mathrm{My})$

Tube Feeding see Enteral Feeding

Tuberculosis Vaccines see BCG Vaccine

Tuberculosis, Laryngeal

resident's page [Mills] $66(\mathrm{Ja})$

Tuberculosis, Osteoarticular

tuberculous petrous apicitis [Kearns] 406 (Je)

Tumor Staging see Neoplasm Staging

Tumor Stem Cell Assay

immunomodulation of nodal lymphocytes in

head and neck cancer [Schuller] $465(\mathrm{Jy})$

Tumors see Neoplasms

Turbinates

approach to large nasoseptal perforations and attendant deformity [Belmont] 450 (Jy)

laser turbinectomy as adjunct to rhinoseptoplasty [Selkin] 446 (Jy)

total inferior turbinectomy for nasal airway obstruction [Ophir] 93 (Fe)

Tyformin

peritonsillar abscess (letter) [Richardson] 135 (Fe)

Tympanic Cavity see Ear, Middle

Tympanic Membrane

is there an auriculovagal reflex producing cardiac dysrhythmias? (letter) [Moorthy] 631 (Se)

proximal symphalangia and stapes ankylosis [Cremers] 765 (No)

role of allergy in pathogenesis of otitis media with effusion [Doyle] $502(\mathrm{Au})$

treatment of Meniere's disease by intratympanic injection with lidocaine [Fradis] 491 ( $\mathrm{Au}$ )

Tympanometry see Acoustic Impedance Tests

Tympanostomy Tube Insertion see Middle Ear Ventilation

Tympanum see Ear, Middle

Ultrasonics

measurement of alternative blood flow in porcine panniculus carnosus myocutaneous flap [Cummings] 598 (Se)

pulsed, auditory evoked potential alterations induced by [Moore] 309 (My)

United Nations

deafness in developing countries, approaches to global program of prevention [Wilson] 2 (Ja)

United States Occupational Safety and Health Administration

hospital-based helicopter, threat to hearing? [Pasic] $507(\mathrm{Au})$

United States Public Health Service

otitis media at Canyon Day, Ariz, 16-year followup in Apache Indians [Todd] 606 (Se)

Uvula

diagnosis and management of obstructive sleep apnea, multidisciplinary approach [Orr] 583 (Se); II. [Moran] 650 (Oc)

Veins

V

advances in laser skin surgery for vascular lesions [Keller] 437 (Jy)

Velopharyngeal Insufficiency

otitis media at Canyon Day, Ariz, 16-year followup in Apache Indians [Todd] 606 (Se)

Ventilation, Mechanical see Respiration, Artificial

Ventilation, Middle Ear see Middle Ear Ventilation

Vertigo

perspectives on pharmacotherapy of [Zee] 609
Vertigo-Continued

(Se)

Vertigo, Aural see Meniere's Disease

Vimentin

cytoskeletal proteins in oncocytic tumors of pparotid gland [Gustafsson] $99(\mathrm{Fe})$

Viscosity

study of mucus glycoproteins in secretory otititis media [Brown] 688 (Oc)

Vitamin A Deficiency

metabolic facial paralysis in infant [Sillman] $\$ 822$ (De)

Vocal Cord Paralysis

laser arytenoidectomy [Lim] 262 (Ap)

twisted larynx, clinical syndrome (ietter) [Lewwy] (ed. reply) [Bailey] $557(\mathrm{Au})$

Vocal Cords

conservation laryngeal surgery, critical analyssis [Maceri] 361 (Je)

feasibility of subtotal laryngectomy based , on whole-organ examination [Robbins] $356(\mathrm{Je})$ )

pathogenesis of protruded false vocal fold [Hoonjo] 398 (Je)

porous polyethylene in reconstructive head annd neck surgery [Berghaus] $154(\mathrm{Mr})$

Voice

difficulty in high-pitched phonation by laryngeeal trauma [Hirano] $59(\mathrm{Ja})$

primary restoration of, at laryngectomy [H:Iamaker] $182(\mathrm{Mr})$

Voice Disorders

Kaposi's sarcoma in patient with AIDS, ressident's page [Lanser] $486(\mathrm{Jy})$

3-dimensional distribution of neuromusculilar junctions in human cricothyroid [De Vito] 1110 (Fe)

Voice Quality see Voice

Warthin Tumor see Adenolymphoma

Wegener's Granulomatosis

oral features of [Handlers] 267 (Ap)

Whooping Cough

prevention of hearing impairment from infectioon and ototoxic drugs [Catlin] 377 (Je)

Wound Infection

skin wound approximation with new absorbablile suture material [Webster] $517(\mathrm{Au})$

Wounds and Injuries

auricular perichondritis secondary to acupunecture [Davis] 770 (No)

difficulty in high-pitched phonation by laryngeaal trauma [Hirano] 59 (Ja)

Wounds, Gunshot

posttraumatic pseudoaneurysm of extracraniaal middle meningeal artery [Jay] 264 (Ap)

Wounds, Nonpenetrating

medial orbital blow-out fracture with entrapi)ment [Rauch] 53 (Ja)

Wrestling see Sports

X Chromosome

X-linked progressive mixed deafness with peri-ilymphatic gusher during stapes surgery [Cre- mers] 249 (Ap)

X-Ray Tomography, Computed see Tomogra-phy, X-Ray Computed

$X-R a y$, Diagnostic see Radiography

Z

Zeugmatography see Nuclear Magnetic Reso-)nance

Zygoma

calvarial grafts for midface rehabilitation [Cin-:berg] $434(\mathrm{Jy})$

malar fractures associated with exophthalmoss [Godoy] $174(\mathrm{Mr})$

use of malar bone graft to augment skull-base access [Mann] $30(\mathrm{Ja})$

Zygomatic Fractures

malar fractures associated with exophthalmos:s [Godoy] $174(\mathrm{Mr})$ 


\section{Porous Polyethylene in}

\section{Reconstructive Head and Neck Surgery}

Alexander Berghaus, MD

\begin{abstract}
- Porous polyethylene is a thermoplastic synthetic with a pore size ranging from about $100 \mu \mathrm{m}$ to $200 \mu \mathrm{m}$. In addition to other materials, it is used for alloplastic replacement of auditory ossicles. Experimental and clinical experience in our department in recent years has shown that porous polyethylene, due to its good formability, tissue tolerance, and stability is suitable for use in reconstruction of other cartilaginous and bony structures. Therefore, it has been used successfully in reconstruction of the outer ear, in repairing defects of the facial skull, and in rebasing paralyzed vocal folds. Its use in the inner nose to replace the cartilaginous septum or rebase the mucosa in ozena, however, cannot be recommended. The suitability of the material for alloplastic tracheal replacement is investigated experimentally.
\end{abstract}

(Arch Otolaryngol 1985;111:154-160)

Porov orous, high-density polyethylene (PHDPE) is a sintered synthetic that is superior to the more brittle ceramic in its elasticity and to porous metals in its chemical resistance. For the sintering procedure, powder of low-pressure polyethylene types with a relatively wide melting range is

Accepted for publication Oct 19, 1984.

From the Ear, Nose, and Throat Department, Steglitz Medical Center, Free University of Berlin.

Read before the American Academy of Facial Plastic and Reconstructive Surgery, Palm Beach, Fla, May 11, 1984.

Reprint requests to HNO-Klinik und Poliklinik, Klinikum Steglitz der FU Berlin, Hindenburgdamm 30, D-1000 Berlin 45, West Germany (Dr Berghaus) used. In this way, it is possible to produce plates and tubular and special profiles, as well as shaped parts, which then can easily be formed by sawing, drilling, milling, planing, cutting, punching, and so on, and also welded and additionally shaped thermoplastically. The density amounts to $0.6 \mathrm{~g} / \mathrm{cu} \mathrm{cm}$, the porosity, $40 \%$. $^{1}$ The pore size ranges from 40 to $150 \mu \mathrm{m}$ and can reach $200 \mu \mathrm{m}$ or more (Fig 1 ). The material can be regarded as being only slightly infection prone. ${ }^{2}$

Although in principle it is possible to use the autoclave for sterilization, we prefer ethylene oxide gas sterilization because of the incipient thermoplastic plasticity at about $110{ }^{\circ} \mathrm{C}$. In the ear, nose, and throat field, porous polyethylene is mainly known for its use in alloplastic replacement of auditory ossicles. ${ }^{3}$ Less work has been done in other areas of application. In our clinic, ossicular replacement with porous polyethylene prostheses has been abandoned in favor of the ceramic prostheses. Our experimental and clinical studies with porous polyethylene in recent years have shown that this material, which shows good tissue tolerance and form stability, is suitable for replacement of various bony and cartilaginous structures and for filling certain soft tissue defects. ${ }^{4.5}$

In addition to the tympanoplastic applications already mentioned, experimental and clinical experience also encompasses the following areas: (1) reconstruction of defects in the facial skull; (2) reconstruction of the external ear; and (3) rebasing of vocal folds. The material was also used to rebase the mucosa in ozena and to reconstruct the cartilagenous nasal septum, but cannot be recommended for the inner nose on the basis of our experience. In addition, we are in the experimental stage of working on a tracheal prosthesis composed of porous polyethylene.

\section{CORRECTION OF FACIAL-SKULL DEFECTS}

Various experiments have shown that, in a bony implant bed, there is ingrowth of newly formed bone into the porous polyethylene $e^{6.12}$ of up to $100 \%$ under optimal conditions. In an experimental animal study we performed, ${ }^{5}$ in which a comparison was made between porous polyethylene and a combination of Teflon polymer and carbon fibers, we were able to show that, after implantation in skull defects in guinea pigs, PHDPE evi-

Fig 1.-Porous polyethylene of German origin (scanning electron microscope, $\times 500$ ).

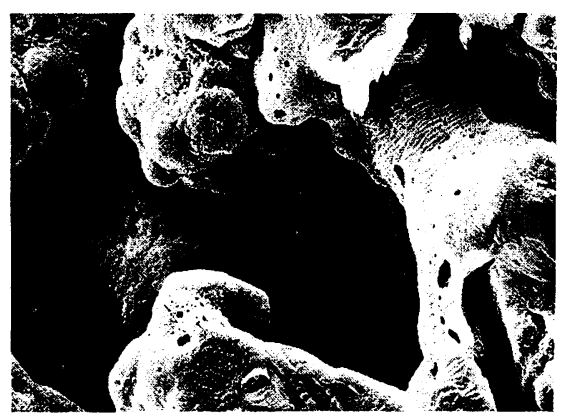



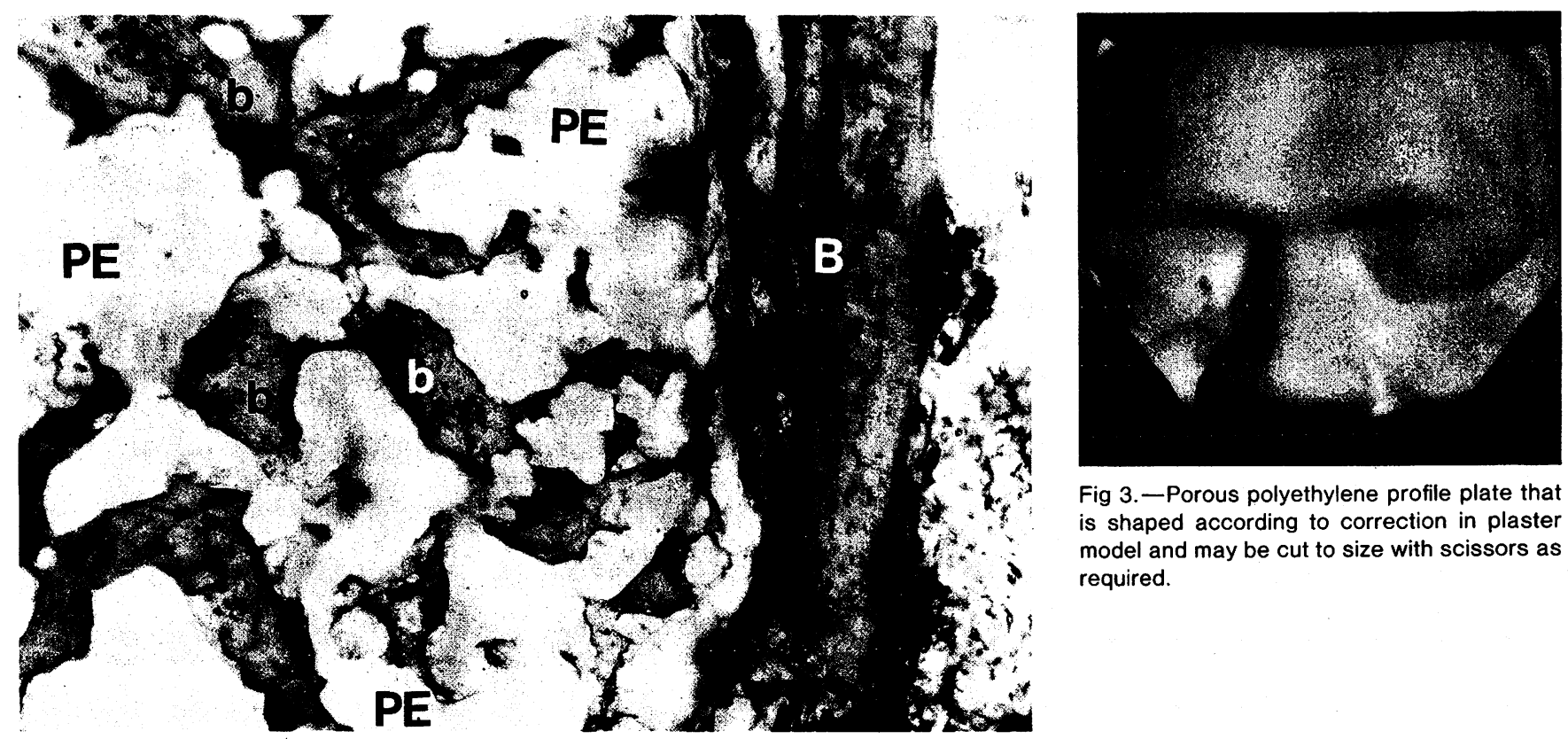

Fig 3.- Porous polyethylene profile plate that is shaped according to correction in plaster model and may be cut to size with scissors as required.

Fig 2.-Bony anchorage of porous polyethylene (PE) six weeks after implantation in calotte of guinea pig. Pores are filled with bone (b). B indicates implant bed (Giemsa stain, $\times 180$ ).
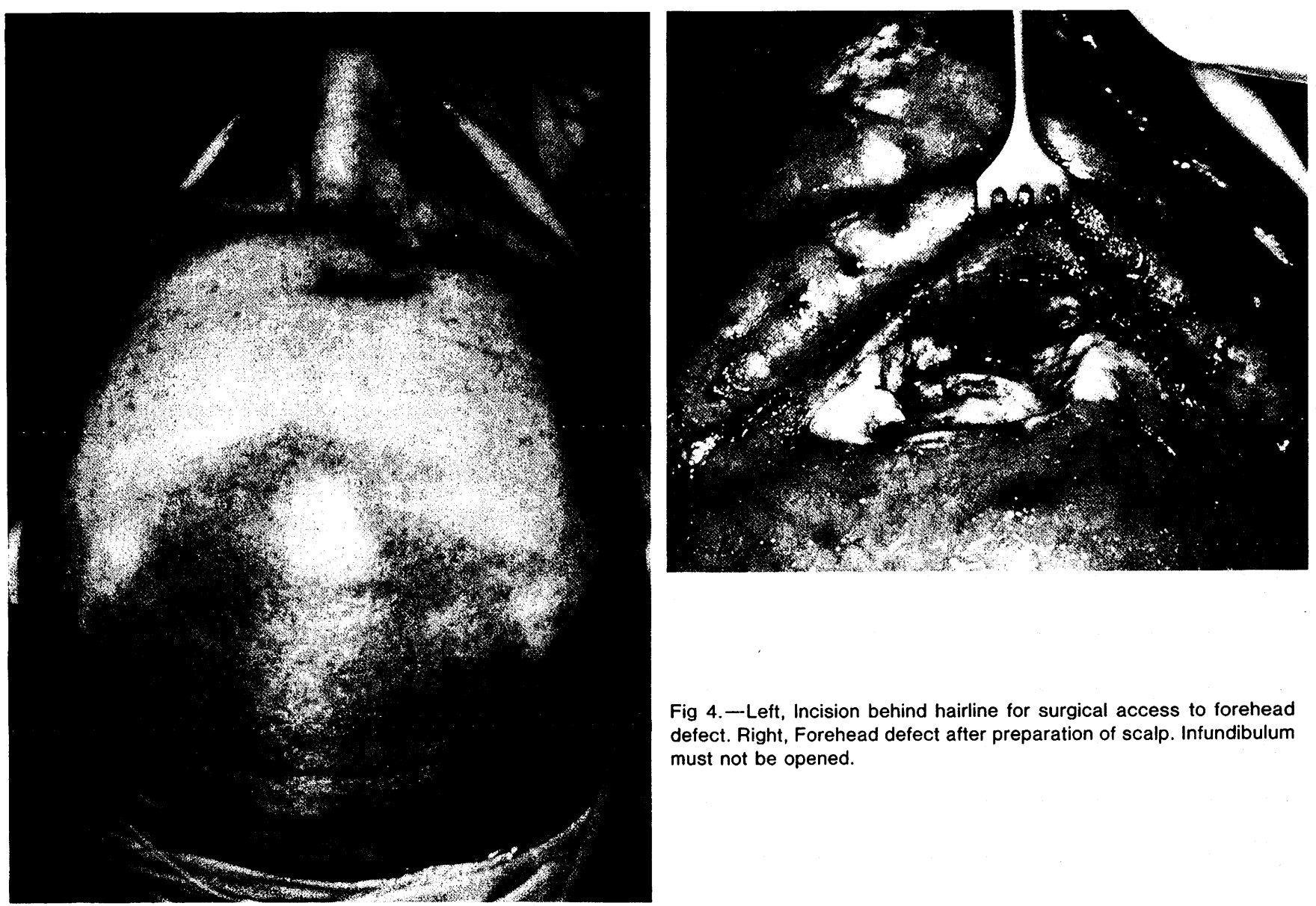

Fig 4.- - Left, Incision behind hairline for surgical access to forehead defect. Right, Forehead defect after preparation of scalp. Infundibulum must not be opened. 

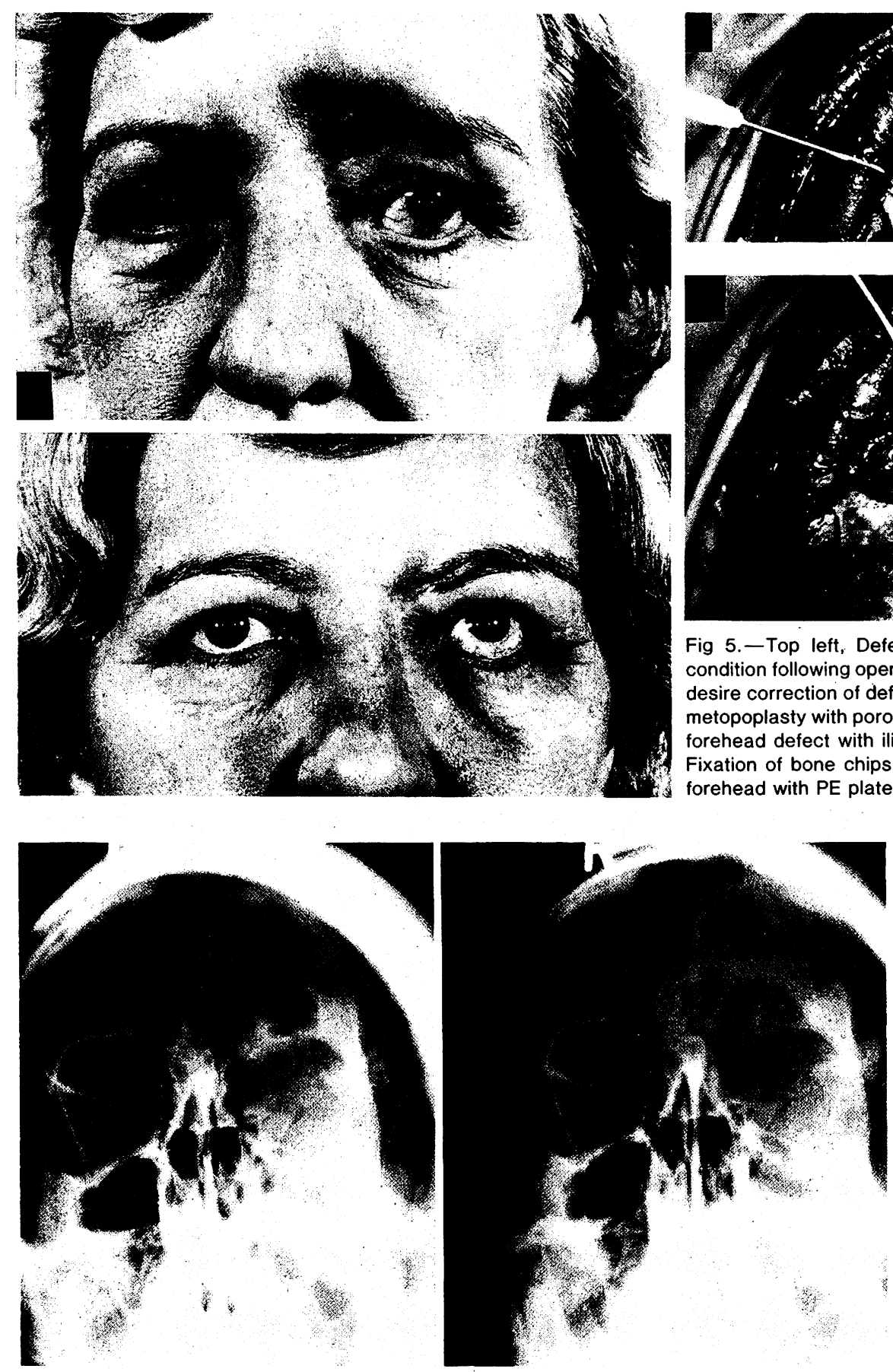

Fig 6. - Left, Roentgenogram of forehead defect depicted in Fig 5. Right, 11/2 years postoperatively. Increasing ossification of the cavity.

dences a considerably more stable bony anchorage than the combination of Teflon and carbon fibers and maintains its form and structure (Fig 2).

Consequently, PHDPE offers favorable preconditions for application in the reconstruction of facial-skull defects, particularly since this synthetic is easily formable, not only with thick polyethylene plate of corresponding size was shaped by pressing the scalpel but also thermoplastical-

We first applied PHDPE of German origin in 1982 for correction of a forehead defect after a mucocele operation. The desired profile was formed on a plaster cast, and then a $2-\mathrm{mm}$
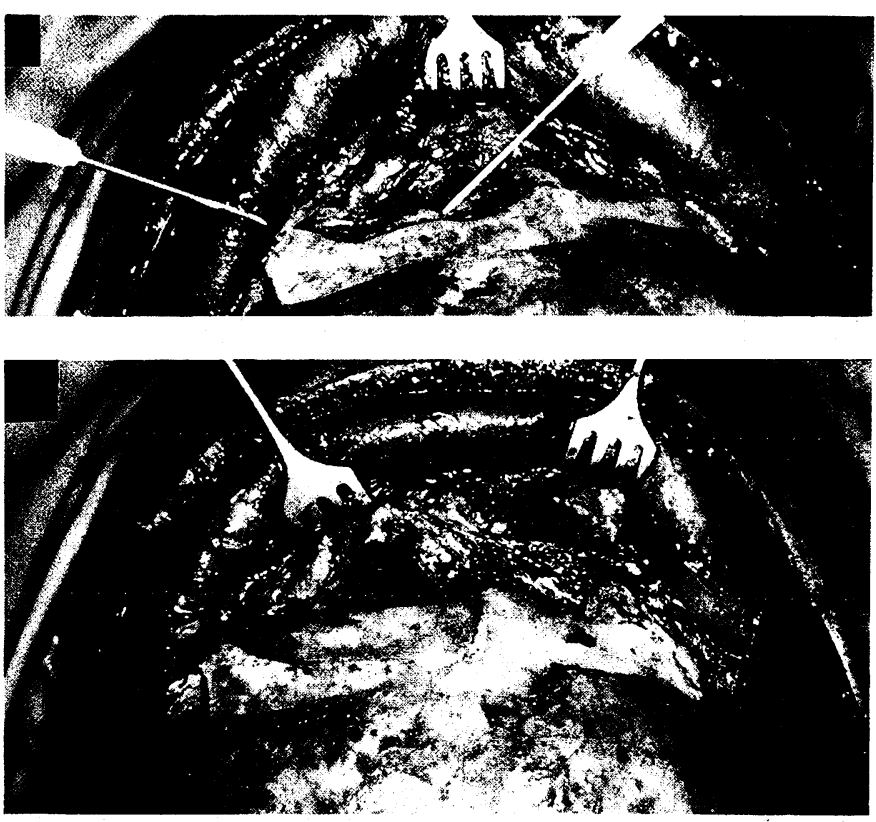

Fig 5.-Top left, Defect of forehead and orbital margin on left in condition following operation of mucocele due to trauma. Patient did not desire correction of defective eye position. Bottom left, Two years after metopoplasty with porous polyethylene (PE) implant. Top right, Filling of forehead defect with iliac crest bones after preparation of scalp flap. Fixation of bone chips with fibrin glue. Bottom right, Final profiling of forehead with PE plate. it to the plaster model at about $130{ }^{\circ} \mathrm{C}$ (Fig 3). After heating, the synthetic can also be formed by "deep drawing" (suction to the model), which may possibly be less damaging to the pores.

Surgical access to the defect is usually created via an arcuate incision behind the hairline (Fig 4). We filled the defect cavity in the patient shown in Fig 5 with fragmented iliac crest bone; the profile plate composed of PHDPE was then implanted above it and fixed with fibrin glue. This permitted a particularly symmetrical and stable reshaping of the forehead with the supraorbital projection, which would not have been possible with bone transplants alone. A year and a half after the operation, roentgenographic examinations of the nasal sinuses showed the expected ossification of the entire preoperatively visualized defect area (Fig 6).

In another case, the defect cavity under the profile plate was not filled with bone but with porous polyethylene (Fig 7). This was accomplished by using a PHDPE block with multiple perforations, which can be easily shaped to the required size intraoper- 

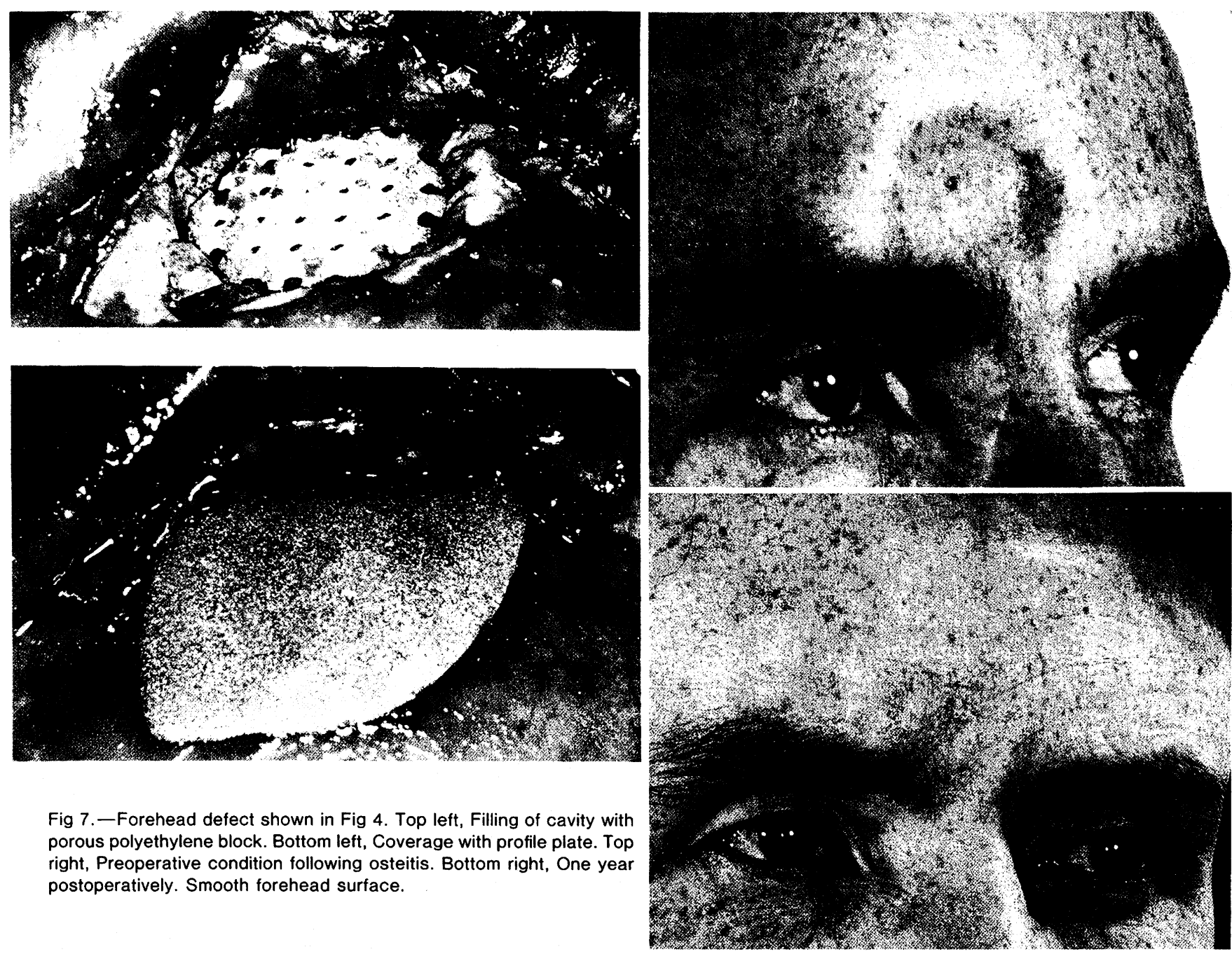

Fig 7.-Forehead defect shown in Fig 4. Top left, Filling of cavity with porous polyethylene block. Bottom left, Coverage with profile plate. Top right, Preoperative condition following osteitis. Bottom right, One year postoperatively. Smooth forehead surface.

atively with the scalpel. The drill holes facilitate ingrowth of connective tissue and bone and reduce the total mass of the synthetic, the pores of which must fill up with the ingrowing bone.

In this patient as well, follow-up roentgenograms a year later gave evidence of an osseous, or at least, a dense fibrous obliteration of the former defect cavity (Fig 8).

The synthetic can also be applied in the described manner when, after a trauma, larger fragments of the frontal bone are missing and the skin has grown directly onto the dura (Fig 9).

\section{SURVEY OF RESULTS}

To date, four frontal and orbital margin defects have been corrected with porous polyethylene. The defect cavity was filled with autogenic iliac crest bone in one case and with perfo-
Fig 8. - Roentgenogram of defect seen in Figs 4 and 7 . Top, Preoperative roentgenogram. Bottom, One year postoperatively.

rated blocks of PHDPE in the three other cases.

The postoperative follow-up period extends from three months up to $2 \frac{1 / 2}{2}$ years. Complications such as infection, suture dehiscence, rejection, skin necrosis, or shifting of the implant have not been observed in any of the cases. A small seroma was tapped once shortly after the operation in only one case. In all cases, the cosmetic result was to the greatest satisfaction of both the patient and the surgeon.

\section{RECONSTRUCTION OF THE EXTERNAL EAR}

Reconstruction of the external ear not only requires sufficient suitable skin, but also a stable supporting

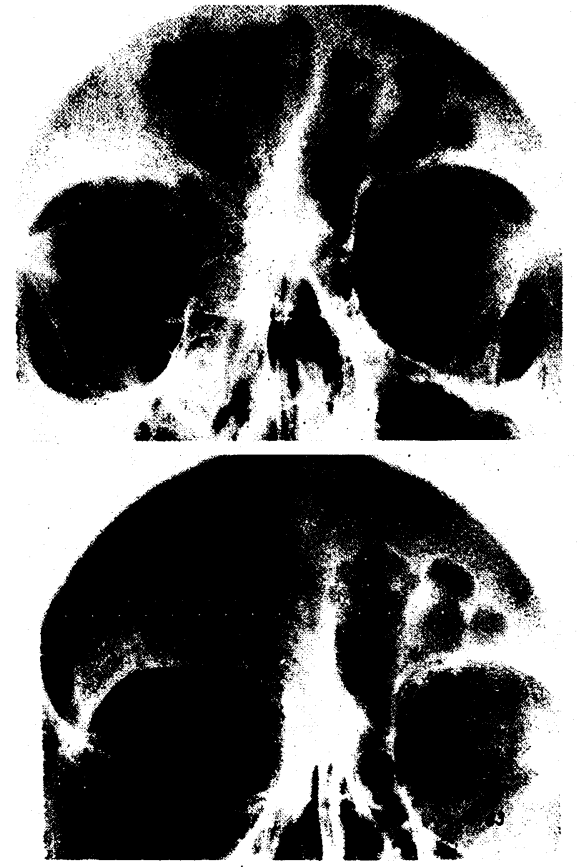




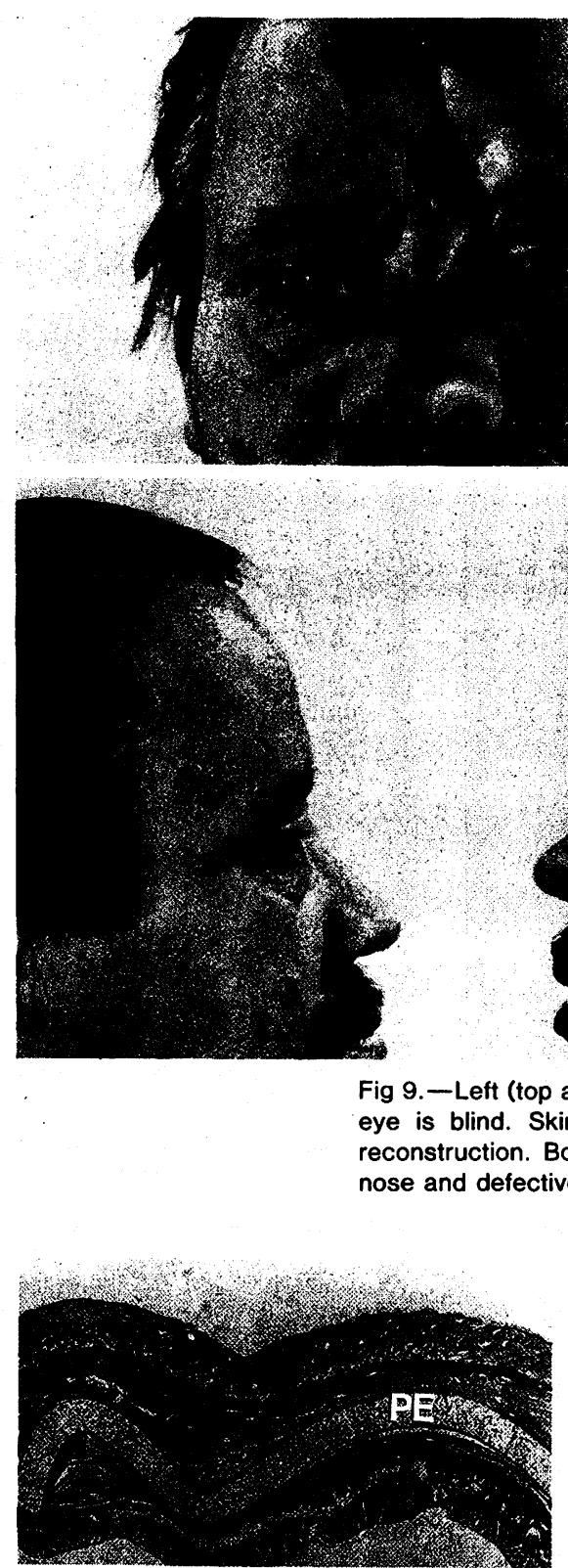

Fig 10.- Shaped porous polyethylene (PE) implant under skin of rat. Adaptation of skin to form provided. Pores of synthetic filled with connective tissue (hematoxylin-eosin, $\times 4$ ).

structure, which is expected to have the following properties: stability of shape, good tissue tolerance, a low absorption rate and the capacity for relief formation through good skin adaptation.

In a comparative experimental animal study, we tested Teflon felt, polyterephthalate velour, combination of Teflon polymer and carbon fibers, and PHDPE to determine their suitability for this purpose. ${ }^{4}$ Subcutaneous implants of these materials in rats were supposed to make possible the permanent formation of a skin fold. After a ten-month observation period, it became evident that only PHDPE fulfilled the requirements. The other synthetics failed, mainly because the supporting structures, being too soft, were pressed flat by skin tension (Fig 10).

For reconstruction of the external ear, we made a supporting frame of PHDPE and first used it in 1982 in a case where the external ear had been nearly lost due to abscess-forming perichondritis. As a result of the suppuration, the cartilage had disappeared almost completely except for a few rudiments, and only the cutaneous sheath remained (Fig 11, a). After the acute inflammation had subsided, we implanted the polyethylene framework before scarry skin shrinkage had occurred and only had to perform a minor cosmetic correction seven months later. After two years, the external ear showed a satisfactory relief; the skin adapted well to the implant, as was to be expected from the results of the animal experiments (Fig 11, b and c).

The good formability of PHDPE makes it possible to produce delicate supporting structures adapted to the particular needs of individual cases, the ideal basic form showing no points or edges. For correction of microtia, we prefer the fan-flap technique described by Fox and Edgerton ${ }^{13}$ in combination with the suction method by Cronin. ${ }^{14}$

Sénéchal et al ${ }^{15}$ also reported the successful application of PHDPE-supporting structures for reconstruction of the external ear, which may obviate removal of autogenous costal cartilage if the results obtained continue to be favorable.

\section{SURVEY OF RESULTS}

Up to now we have used porous polyethylene four times for the recon- 

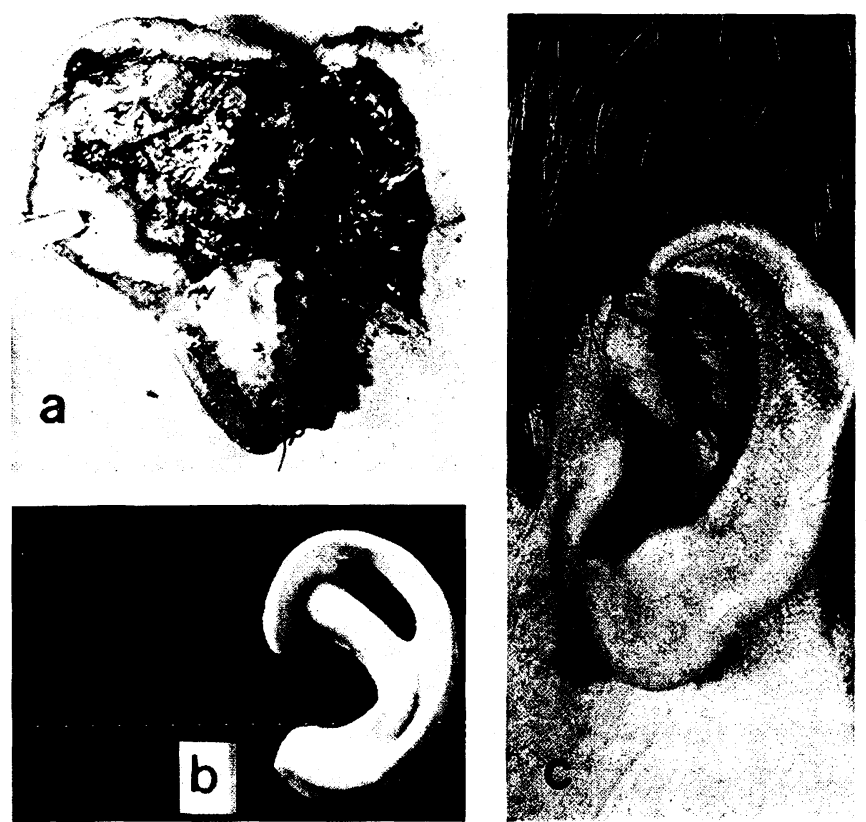

Fig 11.- Letter a shows cutaneous sheath of external ear after abscess-forming perichondritis; $b$, porous polyethylene framework; and c, condition two years postoperatively. After seven months, a part of implant was resected for cosmetic reasons.

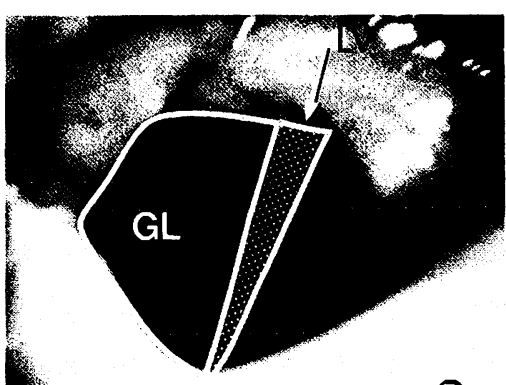

a

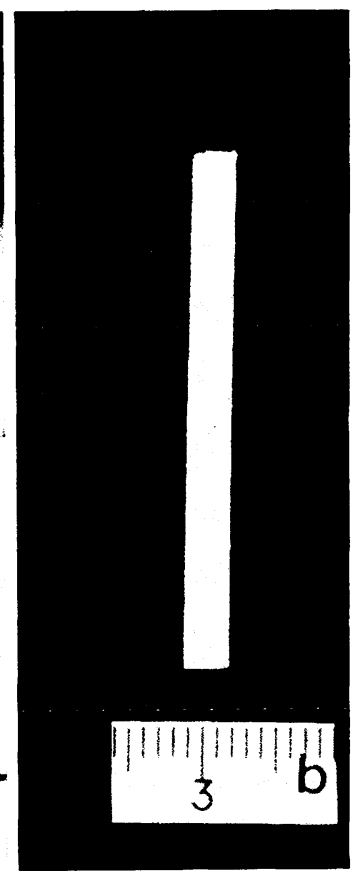

Fig 12. - Missing right vocal cord after cordectomy (a). LV indicates left vocal fold; GL, glottis. Porous polyethylene implant (b). Good view into larynx after thyrotomy with high-frequency jet ventilation (c). Instrument (l) points to prepared tunnel at level of glottis. Scale is given in centimeters.
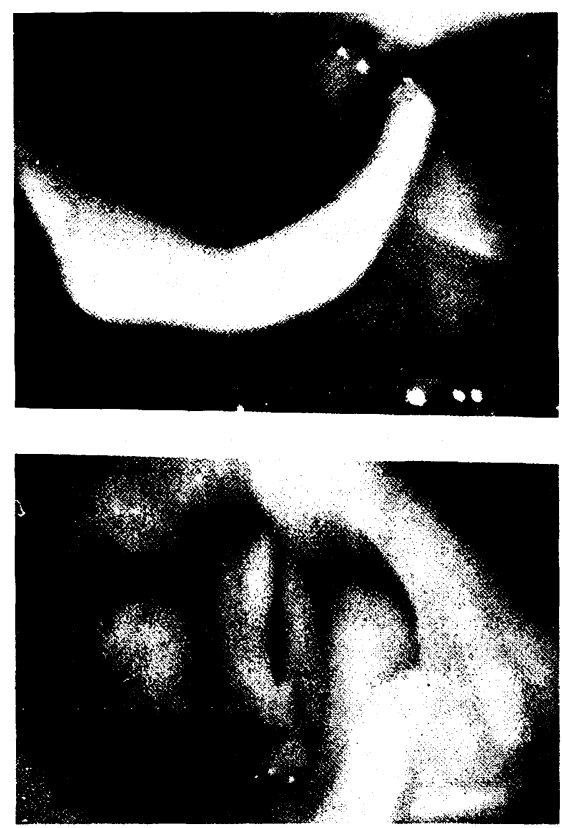

Fig 13. - Two years after bilateral vocal-cord rebasing with porous polyethylene chips. Top, Respiratory position. Bottom, Phonatory position.

struction of external ears: after an abscess-forming perichondritis in one case; one partial, ${ }^{4}$ and two complete reconstructions in microtia. The follow-up period extends from six

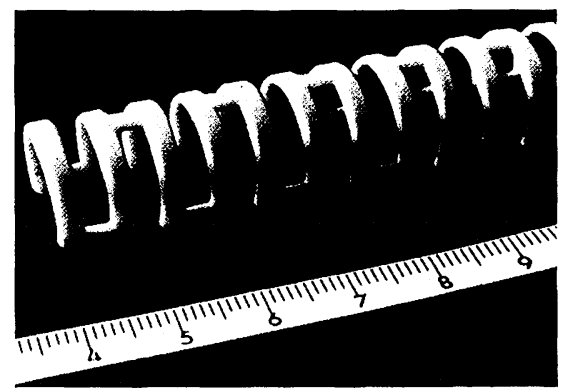

Fig 14. - Our tracheal prosthesis composed of porous polyethylene. Scale is given in inches.

months to $2 \frac{1 / 2}{2}$ years. In the one case of perichondritis, a small suture dehiscence was corrected shortly after the operation, but there were no further complications, in particular no skin necroses or infections. In a case of a patient with microtia, we still plan a positional correction and the formation of the tragus.

Another case of partial reconstruction of the external ear after tumor excision was a failure because the patient manipulated the wound himself immediately after the operation. This led to infection and wound healing disturbances, and soon forced us to perform an implant removal.

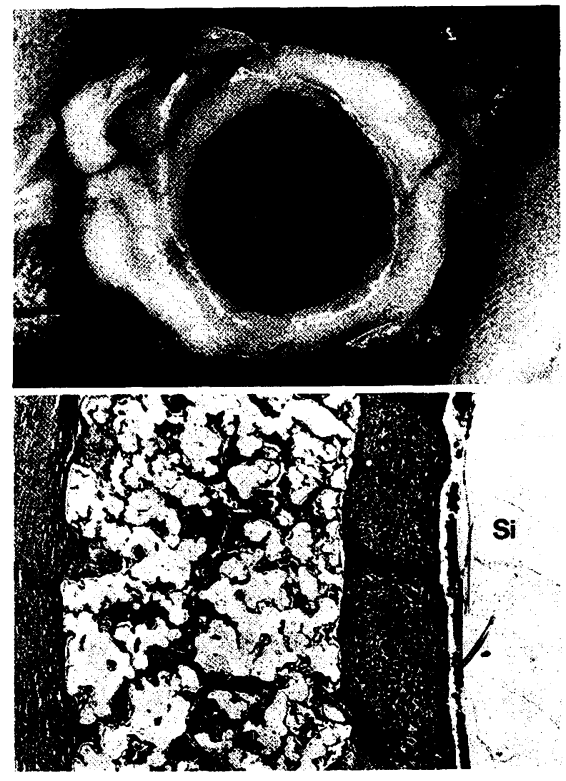

Fig 15. - Tracheal prosthesis after preimplantation in neck muscles of minipig. Lumen was kept open with silicone placeholder. Formation of inner lining. Top, Macroscopic view. Bottom, Histologic examination. Si indicates silicone placeholder $(\times 19)$.

\section{REBASING OF VOCAL FOLDS}

Rebasing of vocal folds may be necessary for paresis of the recurrent nerve, marked hypofunctional dys- 
phonia, and loss of vocal cord due to cordectomy. After several rather unsuccessful therapeutic attempts with the injection of Teflon and with silicone chips, the rebasing of vocal cords in such cases with rounded chips of porous polyethylene, which can be produced in any desired thickness and length, was introduced in our clinic. The larynx is opened by a thyrotomy for this intervention, and, at the level of the glottis, a tunnel is prepared submucosally where the PE chips are inserted (Fig 12).

\section{SURVEY OF RESULTS}

In eight patients thus treated, including one case of bilateral rebasing, revision was only necessary once because an implant, being too large, was exposed and had to be replaced by a smaller one. Examination of the patients one and two years postoperatively showed that rebasing of vocal folds with porous polyethylene chips yielded clearly better results in connection with vocal function than injections, because the vocal cord and laryngeal mucosa fit well on the

1. Berzen J, Braun G, Spengler H: Poröses Polyäthylen. Chemie Technik 1976;5:351-353.

2. Handrock $\mathrm{Ch}$ : Tierexperimentelle Untersuchungen über die Verwendbarkeit eines neuen porösen Polyäthylens im Mittelohr, thesis. Berlin, 1979.

3. Shea JJ: Biocompatible ossicular implants. Arch Otolaryngol 1978;4:191-196.

4. Berghaus A, Axhausen M, Handrock M: Poröse Kunststoffe für die Ohrmuschelplastik. Laryngol Rhinol Otol 1983;62:320-327.

5. Berghaus A, Mulch G, Handrock M: Porous polyethylene and Proplast: Their behavior in a bony implant bed. Arch Otorhinolaryngol 1984;240:115-123.

6. Cestero HJ Jr, Salyer KE, Toranto IR: Bone growth into porous carbon, polyethylene, and polypropylene prostheses. J Biomed Mater Res 1975;9:1-7.

7. Klawitter JJ, Bagwell JG, Weinstein AM, et al: An evaluation of bone growth into porous smooth porous polyethylene surfacelike the skin on the supporting frame structures for the external ear-and thus a smooth vocal cord edge develops $^{16}$ (Fig 13).

The good results obtained with this material could justify the performance of thyrotomy, which doubtlessly constitutes a principle disadvantage of the method. It caused no complications for any of our patients, nor were any of them bothered by the fine scar on the neck. The follow-up period extended from three to four years in seven patients and six months in one patient. Only in one case did the operation not result in an improvement of the vocal function.

\section{COMMENT}

Several attempts at treating ozena by rebasing the lining of the main nasal cavity with PHDPE chips must be regarded as failures, just as the septum reconstruction that was also carried out with such chips, because all these implants were rejected from the nasal cavity after four weeks to one year postoperatively. We there-

\section{References}

high density polyethylene. $J$ Biomed Mater Res 1976;10:311-323.

8. Mayer RD, Moyle DD, Sauer BW: Fracture of porous polyethylene-bone composite. J Biomed Mater Res 1983;17:59-70.

9. Skinner HB, Shackelford JF, Lin HJ, et al: Tensile strength of bone (bone/porous polyethylene) interface. Biomater Med Devices Artif Organs 1979;7:133-140.

10. Spector M, Flemming WR, Sauer BW: Early tissue infiltrate in porous polyethylene implants into bone: A scanning electron microscope study. $J$ Biomed Mater Res 1975;9:537542.

11. Spector M, Flemming WR, Kreutner A: Bone growth into porous high-density polyethylene. J Biomed Mater Res 1976;10:595-603.

12. Spector M, Harmon SL, Kreutner A: Characteristics of tissue growth into proplast and porous polyethylene implants in bone. $J$ Biomed Mater Res 1979;13:677-692. fore prefer the transplantation of autogenous or conserved cartilage in the inner nose.

At the moment, we are working on an alloplastic tracheal replacement made of porous polyethylene in animals. The first results are encouraging, ${ }^{17}$ however, a final assessment is not yet possible.

According to the demonstrated experiences with porous polyethylene, it seems as if this material offers a further auxiliary, beyond all known forms of application, for reconstructive measures in the head and neck area. As always when dealing with alloplastic materials, a prerequisite for successful results is, in addition to a carefully established indication, as complete as possible a coverage of the implant with healthy host tissue.

Fibrin glue was provided as "Tisseel" by the Immuno AG, Vienna. Porous polyethylene was supplied as "RCH 1000 porös" by the Ruhrchemie AG, Oberhausen, West Germany.

Heinz Rösler assisted with the experimental work, and Joanne Weirowski, $\mathrm{PhD}$, helped translate and prepare the manuscript.

13. Fox JW IV, Edgerton MT: The fan flap: An adjunct to ear reconstruction. Plast Reconstr Surg 1976;6:663-667.

14. Cronin TD: Use of a silastic frame for total and subtotal reconstruction of the external ear: Preliminary report. Plast Reconstr Surg 1966; 37:399-405.

15. Sénéchal G, Mamelle G, Rodriguez J, et al: Reflexions sur la reconstruction du pavillon de l'oreille. Ann Otolaryngol 1981;98:367-370.

16. Berghaus A, Zühlke D: Anwendungsmöglichkeiten des porösen Polyäthylens in der rekonstruktiven Chirurgie des Kopf-Hals-Bereiches, in Rettig HM (ed): Biomaterialien und Nahtmaterial. Berlin, Springer, 1984, pp 203-209. Reconstructive Surgery, Gieben, October 1983.

17. Berghaus A: Auto-alloplastic Tracheal Replacement Prosthesis. Transactions of the Second World Congress on Biomaterials, Washington, DC, 1984, p 299. 